THE RISE OF MAN

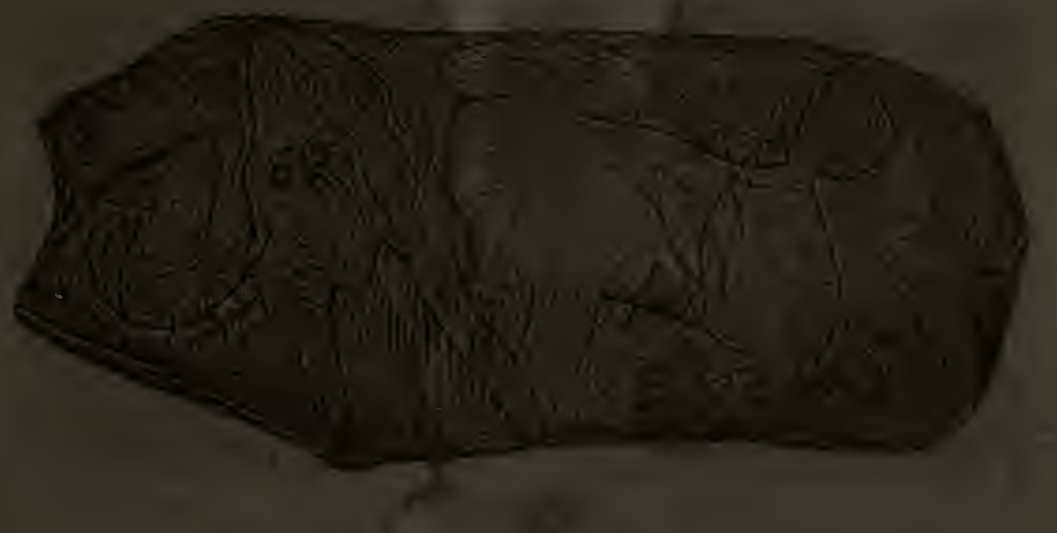

BY PAUL CARUS

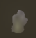





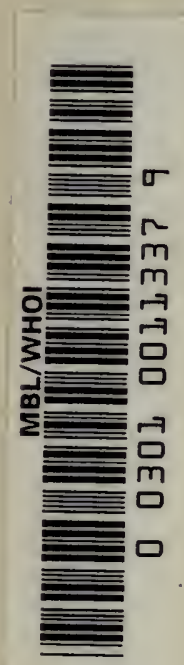








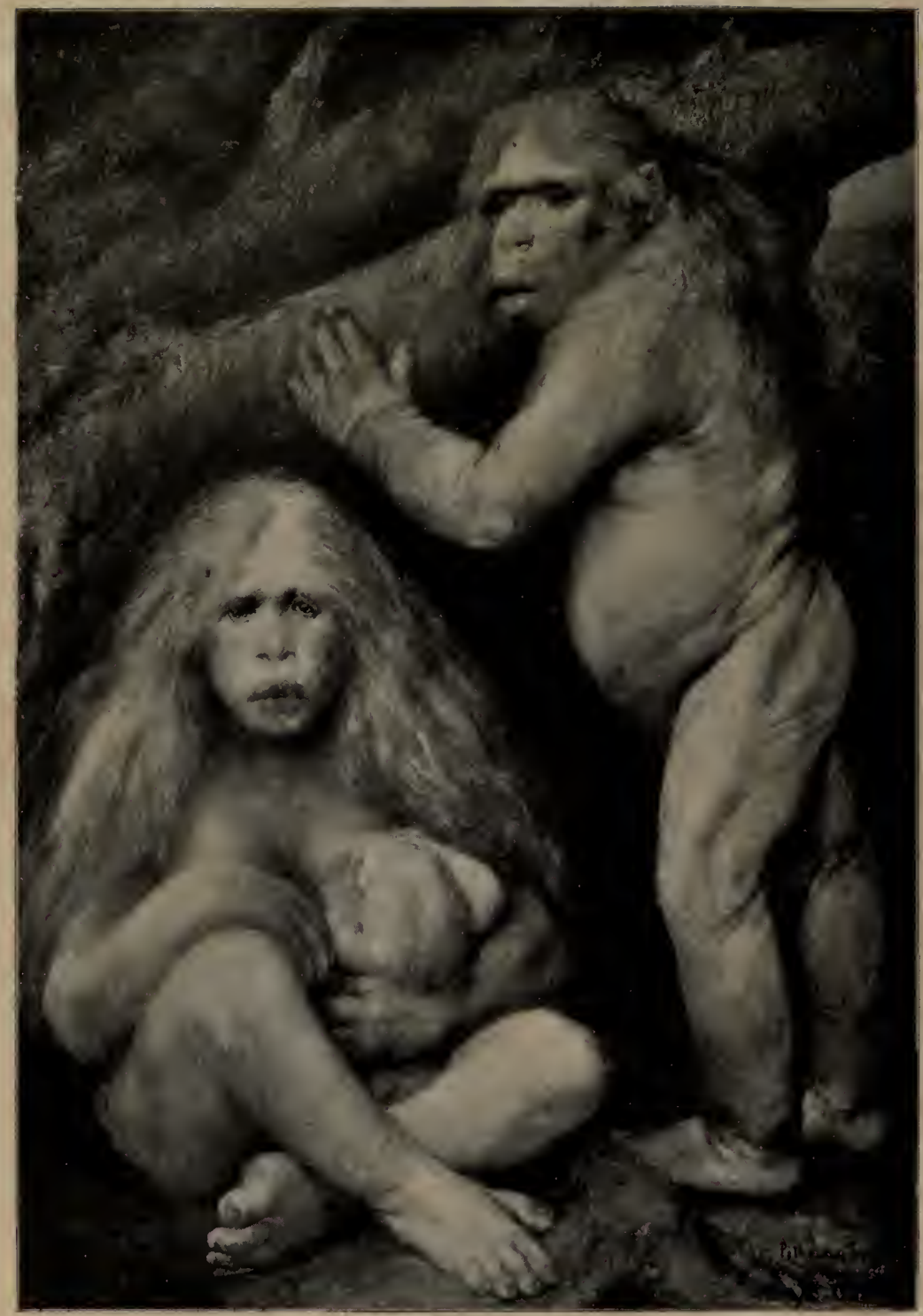

For explanation see page $58 \mathrm{ff}$.

(By permission of Prof. Frnst Haeckel, Gabriel Max and Franz Hanfstaengel.) 


\title{
THE RISE OF MAN
}

A

\section{SKETCH OF THE ORIGIN OF THE}

HUMAN RACE

\author{
BY \\ PAUL CARUS
}

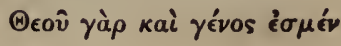

ILLUSTRATED

CHICAGO

THE OPEN COURT PUBLISHING COMPANY

LONDON AGENTS

KEGAN PAUL, TRENCH, TRÜBNER \& CO., LTD. 
Copyright by

The Ofen Court Publishing Co.

I906.

57 


\section{TABLE OF CONTENTS:}

The Divinity of Man. $\ldots \ldots \ldots \ldots \ldots \ldots \ldots \ldots \ldots \ldots \ldots \ldots \ldots$

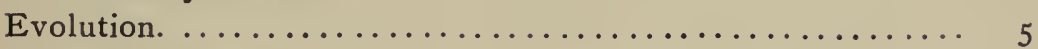

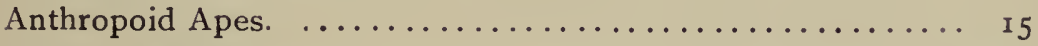

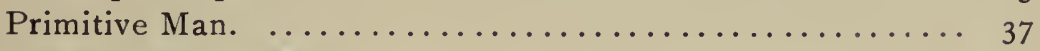

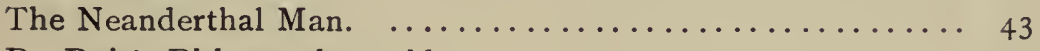

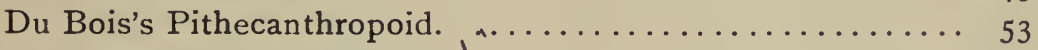

Civilization and the Race. ..................... 6 I

The Triumph of the Best. ................. 78 



\section{THE DIVINITY OF MAN.}

$A^{N}$ old and pious Irish woman (so the story goes) called A at the library for Darwin's Descent of Man, but returned the book speedily, saying, "I thought it was on a 'dacent' man, but I am dis'pinted, it is mere gibberish about apes and that kind o' things."

Whatever errors the good old Irish woman may be guilty of in spelling, the truth is that in spite of the science of its author the book is one-sided, and attempts only to trace the physiological connection of man with a series of lower animals. If the theory of evolution holds good (which is no longer doubted by any true scientist), the descent of man is continuous since the beginning of life on earth. There is no break in the ladder of life, but when we trace the genealogy of man, we ought not to forget the Apostle's word, ${ }^{x}$ who when addressing the Athenians in the market-place of their city, quoted from some of the Greek poets ${ }^{2}$ the line :

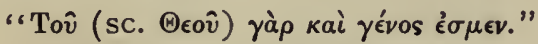

(For God's offspring are we.)

The idea that we are the offspring of God is Greek, not Hebrew, but the sentiment has become a part of our religious ideas. At the time of Christ monotheism had attained its most rigid form among the Jews, and any

1 Acts xvii, 28.

2 The words occur in fragments of Aratus and Cleanthes. 
orthodox rabbi would have scorned the idea of attributing to God offspring in any sense of the word.*

Mohammed who had imbibed similar traditions under similar circumstances in opposition to the Christian idea of divine sonship, declared, for the same reason, most emphatically that "God is neither begotten nor a begetter." The Apostle Paul, however, being born and raised in Tarsus, was accustomed to the Gentile ways of thinking, more than he himself knew, and so he was not offended at the Gentile belief that claimed a divine origin for man. But to prove it according to the method of the age by quoting Scriptures, he had to fall back on a Gentile authority. Paul quotes not the Bible but a pagan poet.

Thus it came to pass in the Gentile Christian Church that the legend of the creation of man from the clay of the ground was given a Gentile interpretation. The whole creation, it was thought, had been made by God, but now we are told that man is the offspring of God. The story in Genesis is now interpreted to mean that the human body was especially formed by God himself, and that God himself blew into the nostrils of the clay figure the breath of life. Whatever the rabbinical meaning of the legend may have been, it was interpreted by Christian exegetists after the precedence of St. Paul in the spirit of the Gentile conception, to denote a unique or separate and indeed a divine origin of man. The idea that man had been made of dust and that finally he should return to dust was now limited to his body, as Longfellow says :

"Dust thou art, to dust returnest, Was not spoken of the soul.".

And the passage in Ecclesiastes (iii, 18-20) where we

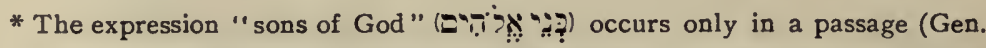
vi, 4) which is quite ancient, reflecting the conception of an age in which the faith of Israel did not as yet differ in any essential point from the religion of the Gentiles. It has always been felt to be out of place in the Old Testament and has continued to be a stumbling block to the orthodox and an acknowledged difficulty to interpreters. 
read concerning "the estate of the sons of men," that "they themselves are beasts," has been simply ignored.

Darwin's views were bitterly opposed, although it would seem more dignified if God had fashioned the first man (not directly from a clod of soil, but indirectly after a long preparation of the material) through series of intermediate stages of lower animals, from the infinitely more refined organism of an anthropoid brute. Yet, even from the standpoint of modern science we can still insist that man, though his body consists of the same material as the dust of the earth, holds an unique position among the rest of creation.

The sway of conservatism, however, is great, and so the people trained in the old views of thought clung with tenacity to a literal belief in the story of Genesis. In spite of all that Darwin said in favor of the kinship of man to the rest of animate creation, almost half a century passed before the doctrine of evolution gained ground and became universally recognized; and there were no other objections to it, than the implication as to man's descent from lower forms of life and the denial of the legend that God had formed him directly from the dust of the earth.

At present there may be no one trained in modes of scientific thinking who does not unhesitatingly accept the doctrine of evolution with all that it implies; but having understood the physiological solution of the origin of man, it may be wise to look at the argument of the reactionary party, whose main contention consists in ridiculing the idea that man was descended from the ape.

When the writer of these lines was a child, he knew a pleasant gray haired teacher of a country parish school, who used to tell the story that when he once explained to his children the first chapter of the Bible, one of the boys, the son of a rich farmer, rose and said: "Mr. Teacher, my father says we are descended from the ape." Our sage old pedagogue cut off all further perplexities by say- 
ing: "It would not be proper here to discuss the private affairs of your family." Thus he imputed the blame of a lowly origin to the families of those who believed in evolution, and had the laugh on his side, but what remained for the others? A direct origin from the dust! They were of the earth earthy.

Reactionary minds who upheld a literal belief in the legend of man's creation from the dust of the ground, went too far when they disclaimed the doctrine of the evolution of all higher life from simple beginnings, but they were right in one point, viz., in the sentiment that man is not of the earth earthy, but that the very feature which constitutes man's manhood is of a nobler origin, and that after all man, in this sense, can claim the privilege of divine sonship. 


\section{EVOLUTION.}

TE'T us investigate the nature of the problem and understand what constitutes the distinctive feature of man and in what way the humanity of man made its first appearance on earth.

The distinguishing characteristic between man and the brute is reason ; and reason, the faculty that sees the general rule in a special example, enables man to foresee the possible or probable course of events, to make plans, to avoid danger, and to sow the seed in summer with the expectation of reaping the harvest in the fall. All other creatures must adapt themselves to surroundings ; man alone can adapt the surroundings as well as all other conditions to his wants.

The question is, whence did the faculty of reason come? Was it innate within the germs of the physiological ancestors of man or did it come to him from without?

We must remind the reader here of the fact that the term "evolution" is really a wrong word. When a common origin of all life on earth was first advocated by naturalists, which was done in the middle of the eighteenth century by Kaspar Friedrich Wolf (1733-1794), and later on by Haller (1708-1777), Gottfried Reinhold Treviranus (1776-1837), Lamarck (1774-1829), Geoffrey SaintHilaire (1772-1844), Goethe (1749-1832), Von Baer (1792-1876), and others, there were two theories offered in explanation: one was called "evolution," or in German 
Auswickelung, i. e., unfoldment (literally, "outrolling") - a theory of development from within, the other "epigenesis," or the theory of development by additional growth from without. According to the theory of evolution, the nature of the higher animals was assumed to be predetermined by the mysterious disposition of their original life-plasma, in about the same way as the chicken, with all its limbs, its bodily and psychic faculties, is somehow pre-existent in the ovule of the egg. However, according to the epigenesis theory, new properties are acquired by experience, and thus it would appear that external conditions determine the further development of life. The term "evolution" was used in those days in its original meaning of something being unfolded (rolled out) from a latent state into a visible and plainly perceptible form, but since Darwin's time, we use the word in place of "epigenesis"; for the theory of epigenesis has practically been established on the basis of observation and experiment, and the Germans speak no longer of Auswickelung, but of Entwickelung. The majority of naturalists of this age hold that growth of the higher life is not directly due to the latent qualities of ancestors, but is the result of new acquirements conditioned by extended experiences under definitely given surroundings. The progress which mankind is making still in its onward march to the higher planes of existence, is due to the lessons of life and not to the mysterious potencies of primordial germs.

The chicken's egg is different from the primordial life-plasma. Its ovule contains in the latent form of dispositions the experiences of all its ancestors-a kind of race-memory which will reproduce the chick type by evolution in the original sense of the term. ${ }^{\mathbf{x}}$

1 This statement is subject to certain restrictions which we do not care to discuss in detail in this connection. The ovule contains the memories of the chickrace, but its growth takes place by repeating the process of epigenesis.

The egg does not contain feathers, or eyes, or a bill, or feet, but certain life- 
If the doctrine of epigenesis be true, we must insist that those features which constitute the manhood of man are not contained in a latent form in his brute ancestors, but they are a new acquisition which comes from without, not from within. Of course we must understand that only that animal which has passed through all the preceding degrees can be graduated to the higher sphere of life, and in this sense the experiences of the lower animal are still preserved and must be presupposed in all future advance.

Reason originates through language. Abstract thought becomes possible by naming things. Names stand for whole classes and thus a speaking animal is able to classify his experiences and distinguish the general features of phenomena from that which is particular and incidental. The uniformities of nature, however, are only the manifestations of those factors which scientists formulate as natural laws. In their totality they constitute the world-order, and they, in short, are the divine presence that pervades the entire domain of creation. Reason is nothing but the tracing of these uniformities, and thus human reason is the divinity of the cosmos reflected in consciousness. In this sense the divine is the more realized in a living creature, the higher its life rises in the scale of evolution, and we can truly say that the upward movement acquires its rationality from above, not from below.

Evolution in the animal world is adaptation to surroundings. The polar bear adapts himself in the color of his skin and in his habits to his environment, while the insects of Madeira lose their power of flight and have to a great extent become wingless. There is a survival of the fittest everywhere, but natural selection does not always favor the strongest and the best. The ablest flyers impulses which under proper conditions will change the yolk into the several organs of a chick's body. Thus in the limited sense of the word, the term "evolution" would be misapplied even here. 
on the islands are swept by the winds into the ocean and only the weak survive, those who are lacking in a special virtue, not the bravest, not the strongest, not the best !

There are also periods in history when society is radically corrupt and the spirit of the time makes it actually impossible for good men to exist and act morally. The evil influences of tyranny, of corruption, or of hypocrisy sweep the brave, the courageous, the honest, the thinking out of existence and allow only the weak, the degenerate, the unthinking to remain. It is true that whatever nation falls under such a blight is doomed. Other nations will take her place, and indeed there have been a number of peoples entirely blotted out in such a way from the face of the globe. We have retrogressive as well as progressive adaptation, and in many cases adaptation is no sign of progress either in the physical world, or the moral progress of human beings. The law of adaptation explains survival, but not progress.

Mr. Spencer defines progress as "a passage from a homogeneous to a heterogeneous state... It is a continually increasing disintegration of the whole mass accompanied by an integration, a differentiation, and a mutual, perpetually-increasing dependence of parts as well as of functions, and by a tendency to equilibrium in the functions of the parts integrated." Complexity, he maintains is a sign of a higher evolution, and it is true-in many respects higher forms of existence are richer, more elaborate, more specialized, than lower forms. But is complexity, therefore, the criterion of progress ? Can we use it as a test whenever we are in doubt in a special case? Does it show us the nature of progress, its meaning and importance?

It appears that Mr. Spencer's explanation is not even generally true, for there are most weighty and serious exceptions which entirely overthrow the validity of this formula. Is not the progress in the invention of ma- 
chinery from the more complex to the less complex? Invent a machine for a special kind of work which is simpler than those at present in use, and the amount and exactitude of work being equal, on the strength of its simplicity alone it will be considered superior and will soon replace the more complex machinery in the market.

Mr. Herbert Spencer, the philosopher of evolution, overlooked the main point when he attempted to explain evolution in terms of matter and motion. Evolution means change of form, and this change of form has a special meaning. Evolution is not a material process and not a mechanical process, and the attempt to solve the problem of evolution on the ground of materialism or mechanicalism (i. e. to express its law in terms of matter and motion) must necessarily be a failure. Mr. Spencer, it is true, recognizes the importance of the formal element, for his view of increasing complexity involves form and change of form. Yet he selects a mere external feature (one that is not even universal) as characteristic of evolution and he neglects the very meaning of the change of form. This meaning remaining as an irresoluble residue in his philosophical crucible might find a place of shelter under the protecting wings of the Unknowable ; but this meaning of the change of form is the very nerve of the question and all other things are matters of detail and secondary consideration.

The evolution of the solar system, being a mechanical process, may find in the Kant-Laplace hypothesis a purely mechanical solution. But the evolution of animal life is not a purely mechanical process. There is in it an element of feeling which is not mechanical. I do not mean to say that the nervous process which takes place while an animal feels is not mechanical. On the contrary I consider all processes which are changes of place, biological processes included, as instances of molar or molecular mechanics. But the feeling itself is no mechanical phe- 
romenon. It is a state of awareness and in this state of awareness something is represented. This state of awareness has a meaning, which may be called its contents.

I do not hesitate to consider the meaning that feeling acquires as the characteristic feature not only of animal but especially also of intellectual life-of the life of man. From meaning-freighted feelings soul-life originates. Iret every special feeling, representing a special condition or object, be constituted by a special form of nerve-action, and we should see the soul, the psychological aspect of nerve-forms, develop together with the organism. A higher development leads naturally, as a rule but not without exceptions, to a greater complexity of nerve-form. Yet it is not this complexity which constitutes the evolution of the soul and the progress in the development of the organism. The progress of soul-life must be traced in the meaning with which the feelings that live in the action of these nerve-forms, are freighted.

What is this meaning?

The different soul-forms (so we may for brevity's sake call these feelings, living in the different nerve-structures) represent special experiences and through these experiences the surroundings of the organism are depicted. The soul accordingly is an image of the world impressed into living substance and depicted in feelings. This however is not all ; the soul is more than that. It is also the psychical aspect of the reaction that takes place in response to the stimuli of the surroundings. And this reaction is indeed the most important part in the life of the soul. The former may be called by a generalized name cognition or intelligence, the latter activity or ethics. The former has no other purpose than to serve as an information for the proper direction and guidance of the latter.

The world is not a chaos of material particles. Blind chance does not rule supreme. On the contrary we see order everywhere and law is the regulating principle in 
all things and processes. The world is not a meaningless medley, but a cosmos which in its minutest parts is full of significance and purport. And this truth has found a religious expression in the God-idea. The world considered in its cosmic grandeur is divine, and when in the process of evolution the soul develops as an image of the world, the divinity of the cosmos is also mirrored in the soul. The higher animal life rises, the more does it partake of the divine, and it reaches the highest climax in man and finally in the ideal of a perfectly moral man-in the God-man.

The test of progress must be sought in the growth of soul. The more perfectly, the more completely, the more truthfully the world is imaged in the soul-forms, so as to enable mankind, (the individual man as well as the race,) to react appropriately upon the proper occasions, to be doing and achieving, to act wisely, aspiringly and morally, the higher we have risen on the scale of evolution. It is not the complexity of soul-forms which creates their value, it is their correctness, their congruence with reality, their truth. Evolution sometimes leads to a greater complexity. In the realm of cognition it does so wherever discrimination is needed. But sometimes again it will lead to a greater simplicity. Complexity alone would have a bewildering aspect, it must be combined with economy, and the economy of thought is important because it simplifies our intelligence; it enables us not only to see more of truth at once but also to recognize the laws of nature, the order of the cosmos, and its divinity.

How much more complex is the Ptolemaic system of the stellar universe than that of Copernicus and Kepler and yet no one doubts that the latter on account of its greater simplicity represents a more advanced stage than the former, and ranges higher in the scale of progress.

The test of progress, in one word, is the realization of truth extensive as well as intensive, in the soul of man. 
The more truth the human soul contains and the more it utilizes the truth in life, the more powerful it will be, and the more moral. In this way the soul partakes of the divinity of its creator, call it nature or God; it will come more and more in harmony with the cosmos, it will more and more conform to its laws, it will be more religious, the holier, the greater, the diviner, the higher it develops and the further it progresses.

The characteristic feature of evolution is not, as Mr. Herbert Spencer has it, a change from homogeneity to heterogeneity, but the gradual approach of an acquisition of truth. Those creatures who have a clearer, and broader, and a more correct conception of the world-order that pervades all things, and whose attitude in life is correspondingly adjusted, range higher than those whose souls are only dimly lit up by reason or obscured by error and passion. Not complexity is the test of progress, but rationality. And our conception of truth ought to be, not a mere theoretical insight into certain laws, but truth practically applied; truth respected, cherished, and followed; truth loved, and truth lived out. Truth in this sense, i. e., truth that has become part of our souls, is not mere rational knowledge, but justice, and goodness, and lovingkindness.

Truth, and reason, and goodness are not made of the dust. Reason is a perception of the relational facts, and it supports the ideals of life. Truth and goodness appertain to the immaterial, the purely formal, the spiritual. None of these qualities can be said to be qualities of matter; they do not reside, in whatever latent form it may be, in atoms or molecules. They develop by experience; they are added unto the budding life ; they are the product of an epigenesis, which originates under the guiding influence of the cosmic order with all that it implies, and if there is any sense in the expression "divine," that certainly, and that alone, is worthy of the name. 
The word of Christ that "the Kingdom of Heaven suffereth violence, and the violent take it by force," does not apply to the origin of Christianity alone but is generally true and will find its application whenever an important advance is made in the development of mankind. It must have proved true also when the first intelligent and intelligible sounds were uttered in the little circle of a primitive ape-man family, when cries and shouts changed to words, rendering possible an intercommunication of mind with mind, and begetting in them a purer, a clearer, a more definite, and a truer conception of the world.

Life is like the tree that grows upward. Its roots grow down into the depths of the earth. Its nourishment is from below, but the power that quickens it and imparts to it the strength to rise higher, is the energy furnished by the sunbeams and comes from above.

While it is true that man's body consists of matter and is of the earth, his spirit is spiritual and reflects the divinity of the world which represents itself to the naturalist as the cosmic order of law-ordained conditions. Without taking exception to the truths established by comparative zoollogy, which proves the kinship of man with the lower animals and traces its bodily form back through a series of brute ancestors, assuming the existence of the intermediate type of the so-called pithecanthropos or apeman, we may rightly say that St. Paul's idea of man's divine sonship holds good and will remain true forever.

Having established the two sides of the ascent of man, his rise from below and the help that comes to him from above while he is learning the lessons of life, we shall better appreciate the significance of the period of transition in which man was just emerging from the brute state and soaring with mighty impulse upward to the higher plane of spiritual life and rational comprehension. No doubt this primitive ape-man must still have been a ferocious 
creature, and we can very well imagine that he was daring and bold and savage. It must have been dangerous for any weaker mammal to cross his path or to fall a prey to his ruthless hands, for he was still thoughtless and inconsiderate. He had to make his living from roots and berries and nuts, perhaps also by eating the flesh of some birds and animals that he might catch, and life must have been hard on him. Yet we must not forget that the tenderer feelings of friendship, conjugal affection, and parental love must have been at least as strongly developed in him as they are in many brute animals, for the probability is that the most essential features that the ape-man acquired in his ascent came not only from his keener intelligence, but also, perhaps even mainly, from an increased refinement of his sentiment.

The doctrine of evolution would have been accepted without much opposition, had it not been for its implication of the descent of man from some brute ancestry. All possible arguments have been exhausted to weaken the theory proposed by Darwin and his successors. How much has been said and written about the "missing link," as if the acceptability of the doctrine of evolution depended solely upon the verification of the transition from the brute animal to the intelligent homo sapiens. The truth is that there are innumerable missing links in the scale of life, and it will forever be impossible to point out every single phase through which man has passed since he started from the beginning.

In the meantime many discoveries of primitive human remains have been made which indicate that there was indeed no gap between the highest ape types and the lower races of man, which corroborates the assumption that man is descended, not from the ape, but after all from some animal kin to the ape. 


\section{ANTHROPOID APES.}

THAT comparisons are odious is an old proverb which 1 is applicable when in judging of the higher animals

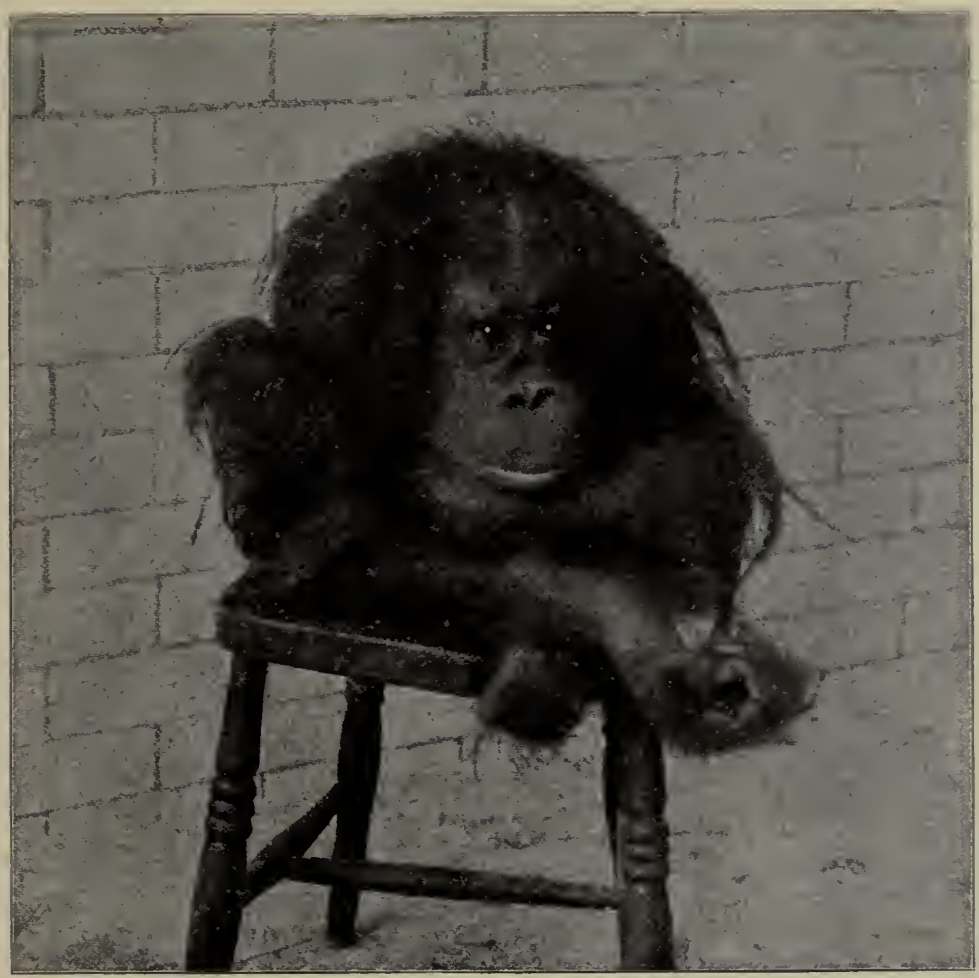

APOLLo.

A new orang-utan in the Zoological Gardens of London.

we are involuntarily struck with a strong similarity to man. Although the apes range indisputably higher than 
any other creatures except homo sapiens, so self-styled, their very aspect is repulsive to us, and if we analyze our sentiments we will be compelled to admit that we have become prejudiced on account of the tacit comparison we make to ourselves. Apes range far below man, and man deems it opprobrious that they should be considered kin to him, and yet how human are they! We abhor them as a caricature of ourselves. They appear like an attempt at manhood which has turned out a conspicuous failure. If an ape did not remind us of a human figure, we would find in the expression of his face, his stature, his carriage, and general deportment, as much beauty as that which we admire in a St. Bernard or a full-blooded Arabian steed.

Let us try to divest ourselves of the odium of comparisons and consider the ape race with that natural interest which we cherish for all life, so as to be impartial in our judgment, and we shall find that the eye of the chimpanzee is remarkably soulful, that the manners of the orang-utan are astonishingly affectionate, and the devotion of the gorilla to his family is manly to a degree that compels respect.

$$
\text { * * * * }
$$

Prof. H. Klaatsch, one of the foremost anthropologists of Germany, speaks pretty authoritatively in the name of his colleagues when he says in a new, large and popular work, Weltall und Menschheit,' that man can scarcely have developed from any of the anthropoid apes, but that both man and ape must have developed from one common ancestor now extinct. The three large groups of anthropoid apes, the gorilla, chimpanzee and orang-utan ${ }^{2}$ must be regarded as degenerates from a higher type, for they are

1 Edited by Hans Kraemer. Published by Bong \& Co., of Berlin, Leipsic, Vienna and Stuttgart. 5 vol. 4 to.

2 The popular pronunciation utang, which has obviously originated by its rhyme with orang, is incorrect. Orang means "man" and utan, "woods" in the Dajak language. 
most like man in their childhood and youth and develop their beast characters as age advances. They have lost their adaptability, and being unfit to survive any considerable change in climate or mode of life, seem to be destined by nature to die out.

Gorilla and chimpanzee are closely related to each other while the orang-utan forms a group by himself. The latter is very delicate in his health and so almost

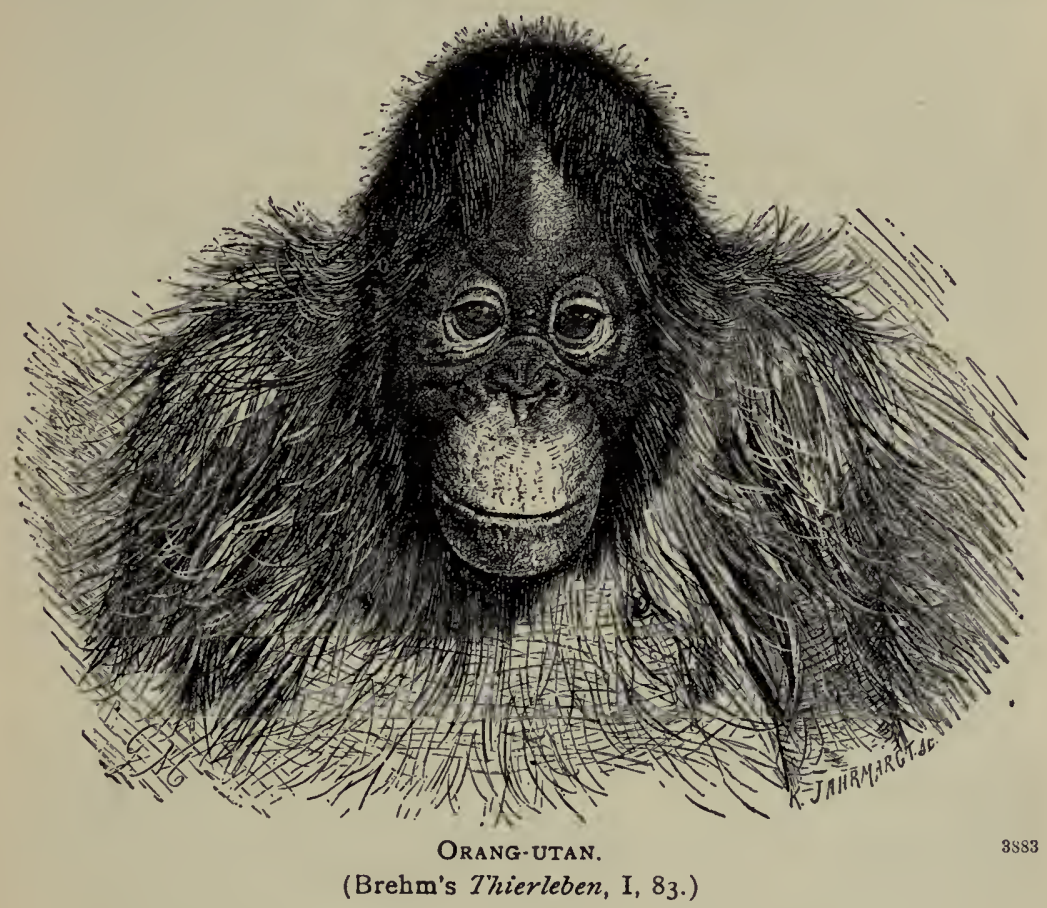

every district harbors a special species. He is found only in Borneo and some of the adjacent islands. We might call him a pessimist, for he has a melancholy temper and is generally in a contemplative mood. He prefers solitude to company and shows a disinclination to leave the wooded swamps of his native district. In captivity he is most human in his affections. It is a common experience with keepers, that the orang-utan if threatened by an admon- 


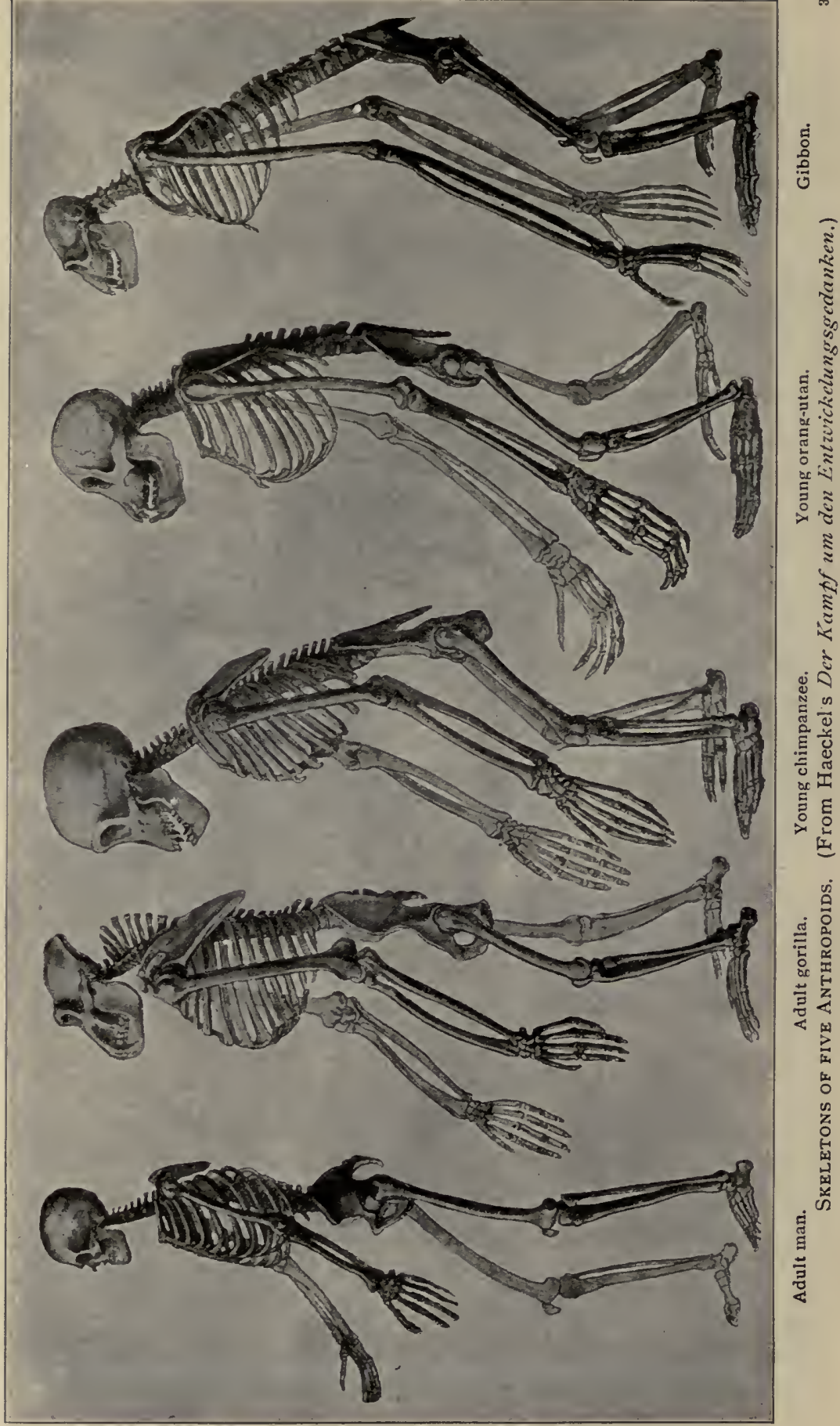




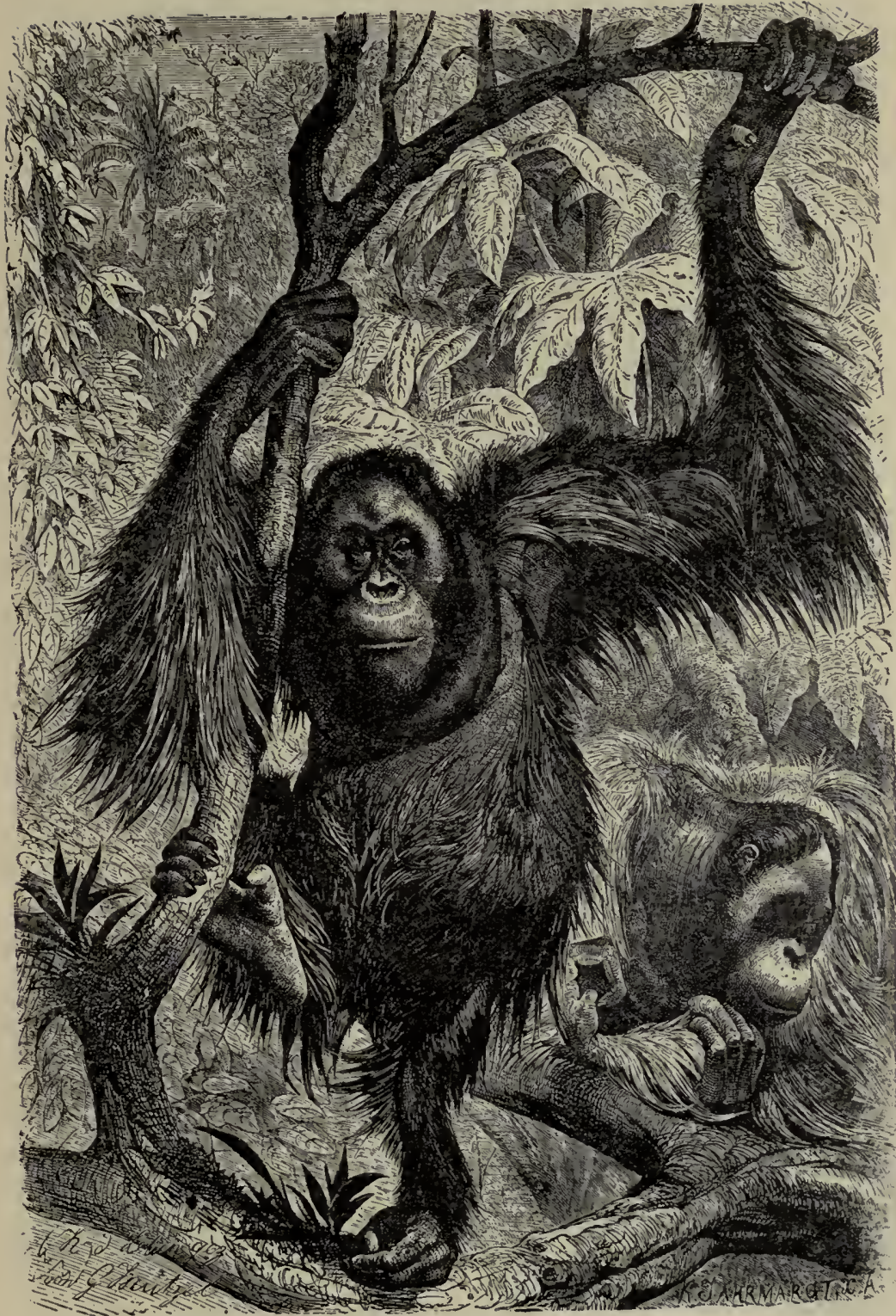

Orang-utans.

8871

(Brebm's Thierleben, I, facing page 83.) 
ishing finger, will come up like a rueful child and plead forgiveness in a plaintive voice. He will embrace the keeper as if to pacify him, and his whole demeanor seems to say, "Do not be angry ; I will be good." It is difficult to keep him long in captivity, however, for he usually dies of consumption after a short time. His mouth is almost of a spherical shape, which makes his face repulsive without, however, succeeding in hiding the good-natured character of his psychical disposition.

The orang-utan appears to us awkward in his movements, but he is not, for he walks along with great rapidity on the stoutest branches in the dense forests of his marshy home. He does not jump but swings himself from tree to tree with unexpected agility. He rarely descends to walk on the ground but remains true to his name, "a man of the forest-trees." Travelers (among them Wallace who has closely observed the habits of the orang-utan in Borneo) declare that he is fearless and peaceful. There are no animals stronger than he except the crocodile, and if a crocodile dares to attack either himself or a member of his family, he throws himself upon the enemy's back and, clutching him from behind, lacerates his throat.

$\because \quad * \quad *$

The gorilla, who among all the brutes has a skeleton most like man's, must once have lived in herds to attain his present state. He is not without the more tender emotions and intelligence, but living now in isolation, and lacking the influence of intercommunication with large numbers of his fellows, he has grown irritable and savage although the reports in regard to his ferocity are greatly exaggerated. He leaves other animals and man alone and is not aggressive without sufficient provocation; but when he sees his family imperiled, he is dangerous in fight. He will accompany the fleeing members of his 


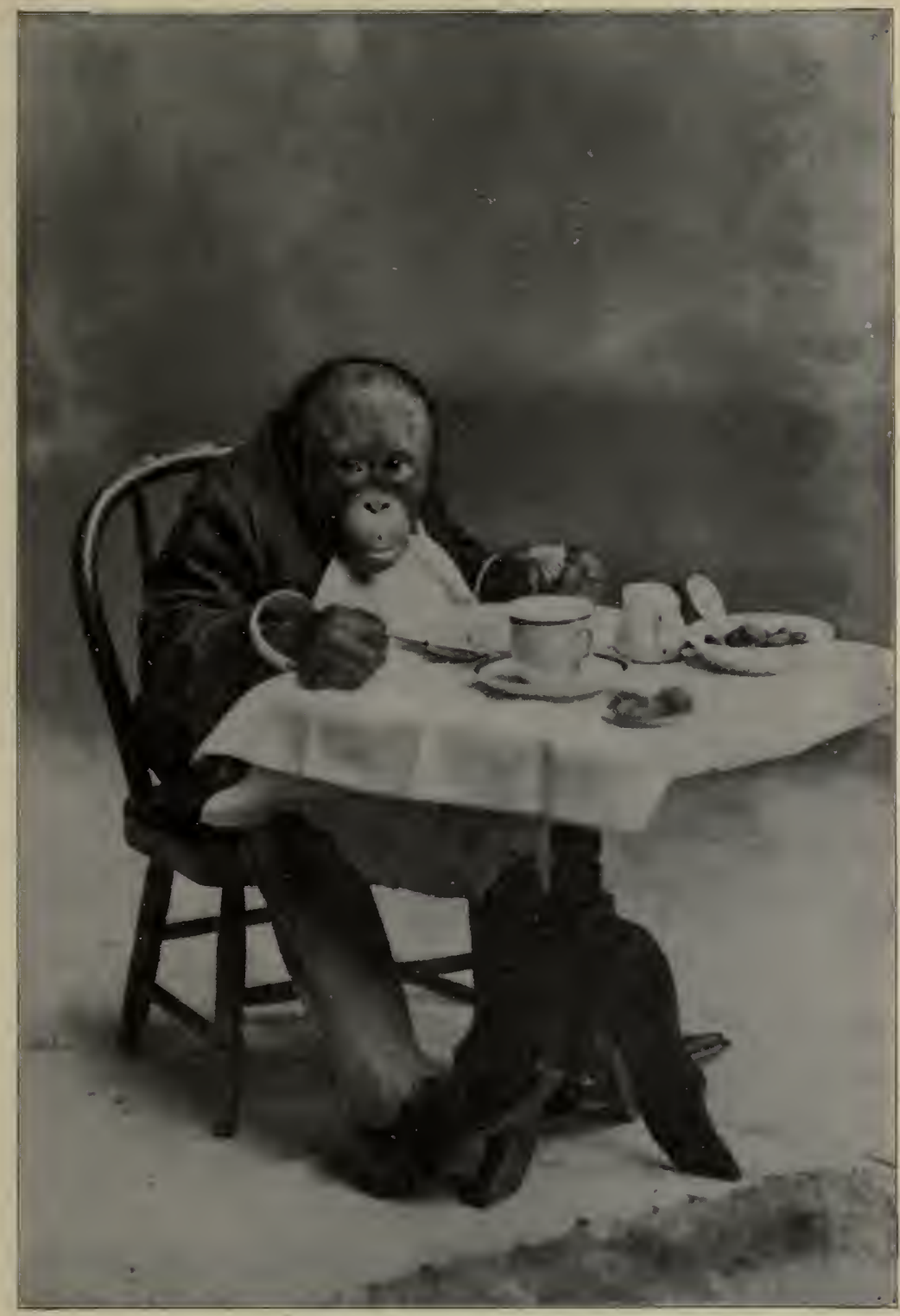

Plate I. Joe the Orang-Utan at Dinner.

6 years old; a member of Edwards' Zoological Exhibition. The Edwards brothers have a special knack of photographing their simian pets in interesting attitudes, and the posing animals seem to say "How human we are!" 


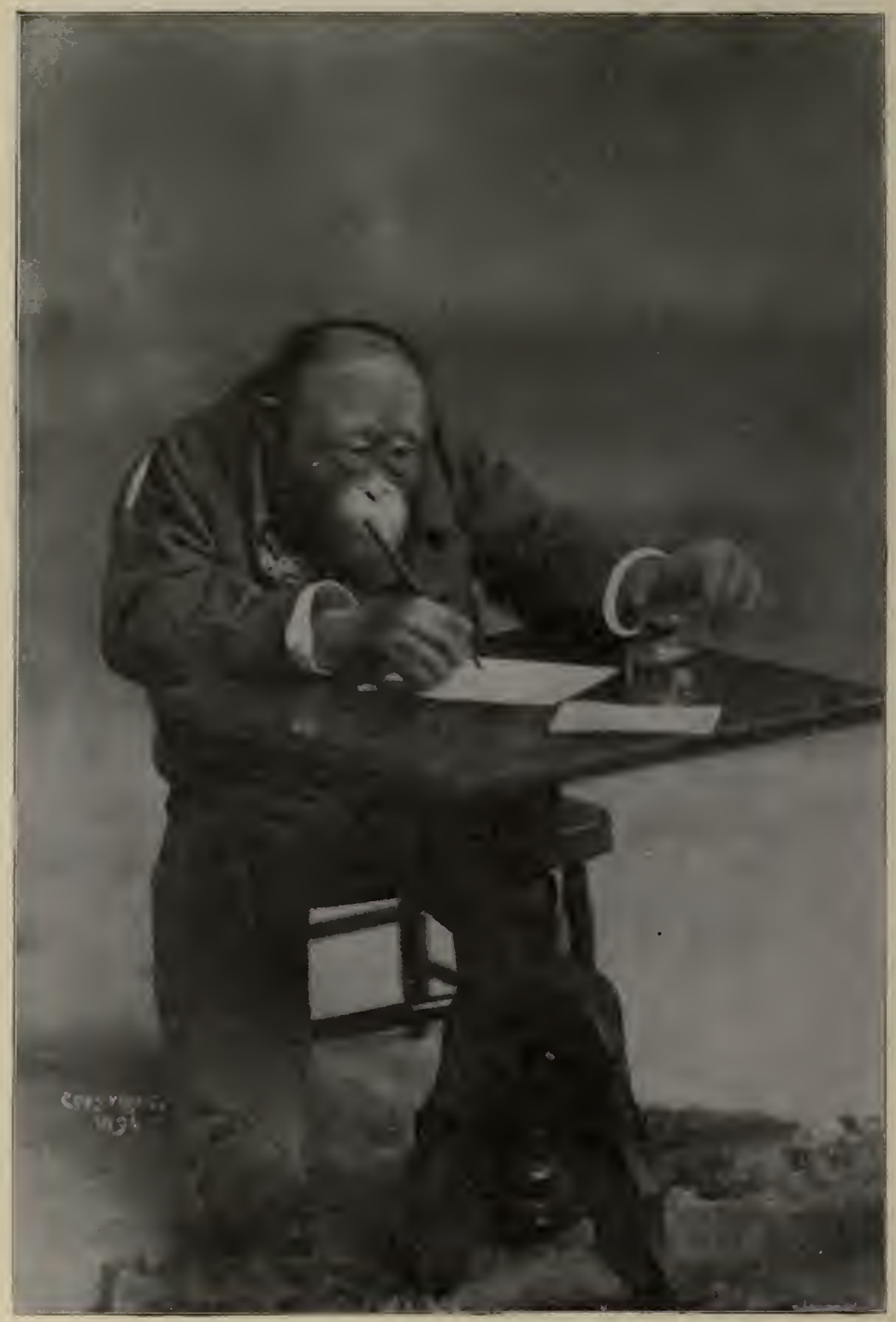

Plate II. Joe the Orang-Utan Writing.

$\mathrm{He}$ is distinguished by his docility, simulating his betters even where he can not do like them. We know he can not write, but here he sits pencil in hand and pretends to write. 


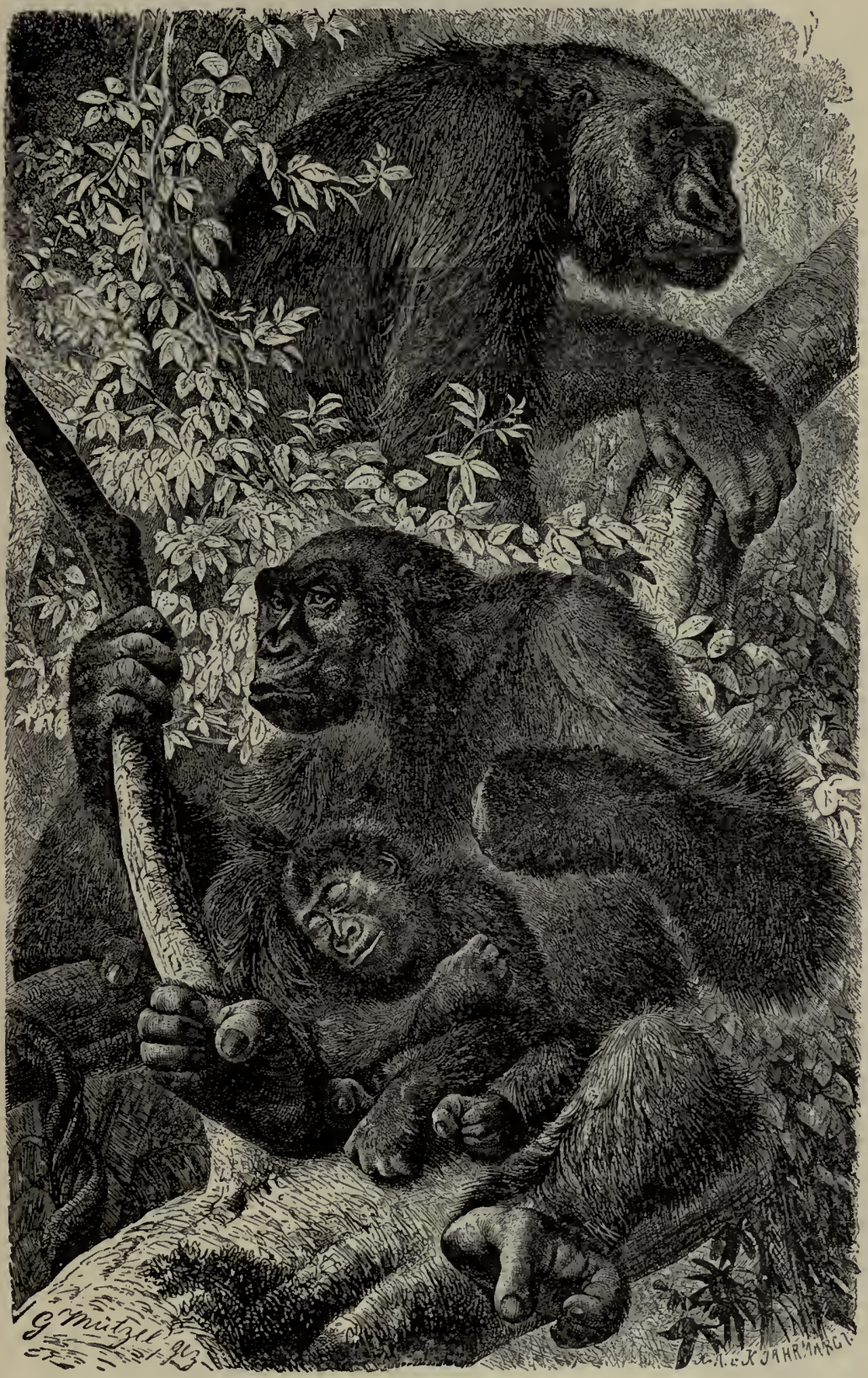

Gorillas

(Brehm's Thierleben I, facing page 56.) 
family for a short distance, and then turn upon the hunter, for he is not a coward and will never turn his back upon an enemy. He challenges his antagonist without hesi-

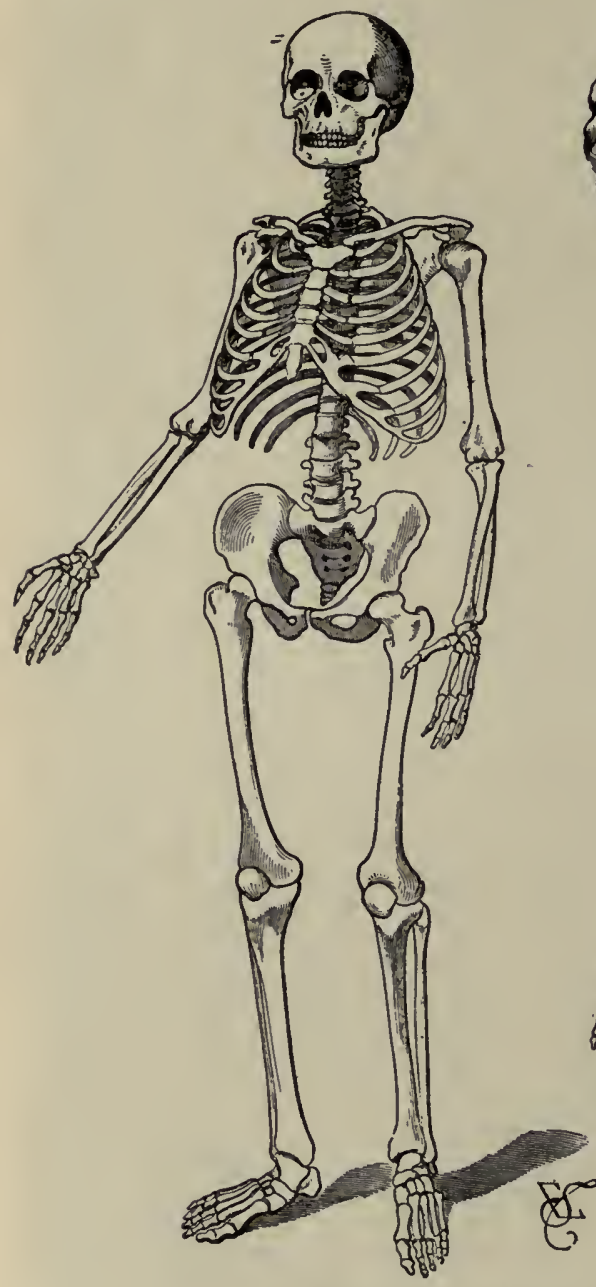

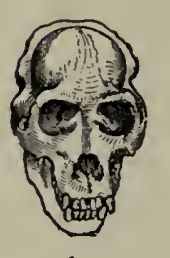

b

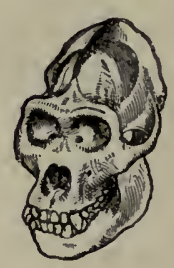

a

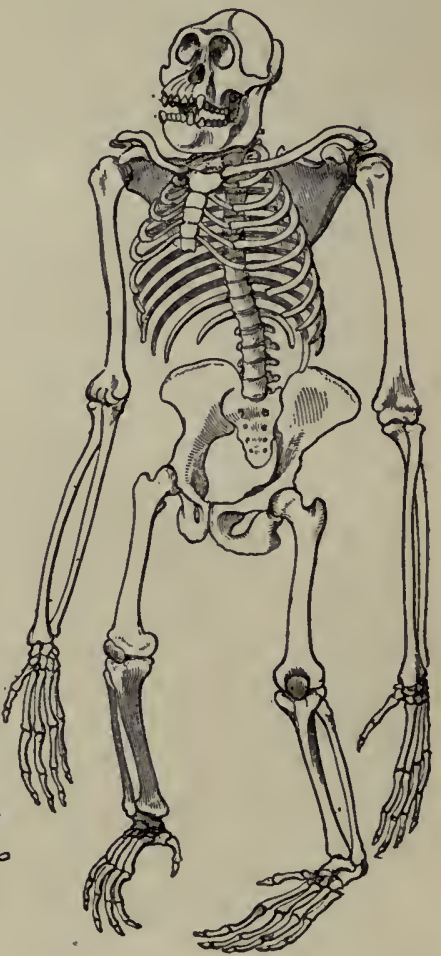

3884

(From the Berlin Anatomical Muselum. Brehm's Thierleben, I, 40.)

tation, his excitement being that of anger, never of fear, and the traveler who is not wary may pay dearly for having braved his wrath. 

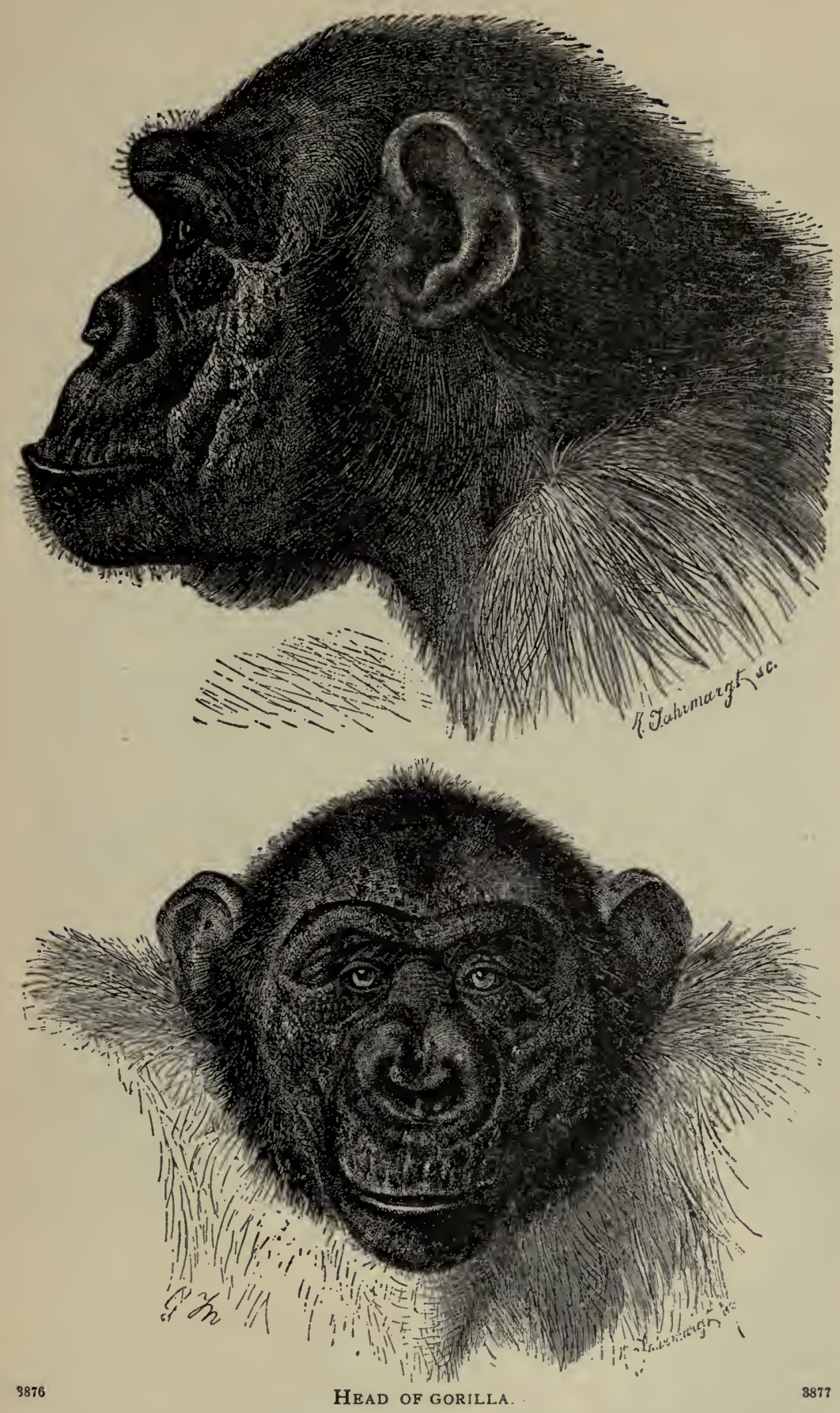

(Brehm's Thierleben, I, 80.)

Dr. Brehm gave the name of "Tschego" to this gorilla about whose classification be seems to have been in doubt. 
Like all other anthropoid apes the gorilla is vegetarian in his diet. He eats berries, ribs of banana leaves, coconuts and similar vegetable food. He seems to possess strong teeth for the purpose of opening nuts whose shells man can break only with a heavy hammer. Being strong he requires much food, and is a voracious eater. By a constant need of new food he has developed migratory habits, and his presence is destructive to all edible plants

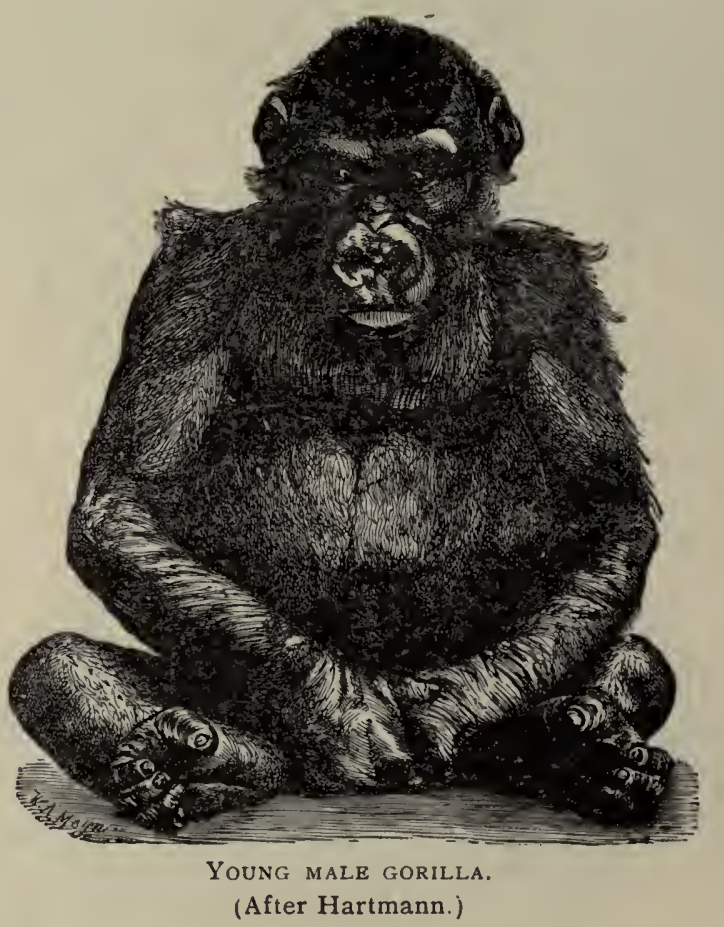

in his neighborhood. $\mathrm{He}$ is an especially unwelcome guest to sugar-cane plantations, where he can do great harm in a short time.

The first historical information about the gorilla we find contained in an ancient work entitled Periplous Hannonis (Expedition of Hanno) which describes the Carthaginian admiral's bold enterprise of founding colonies in 
the far west. He rounded the Sierra Leone and makes the following report :

"The third day after we had sailed and had passed through the torrid streams, we came to a bay called the Southern Horn. In the background, there was an island

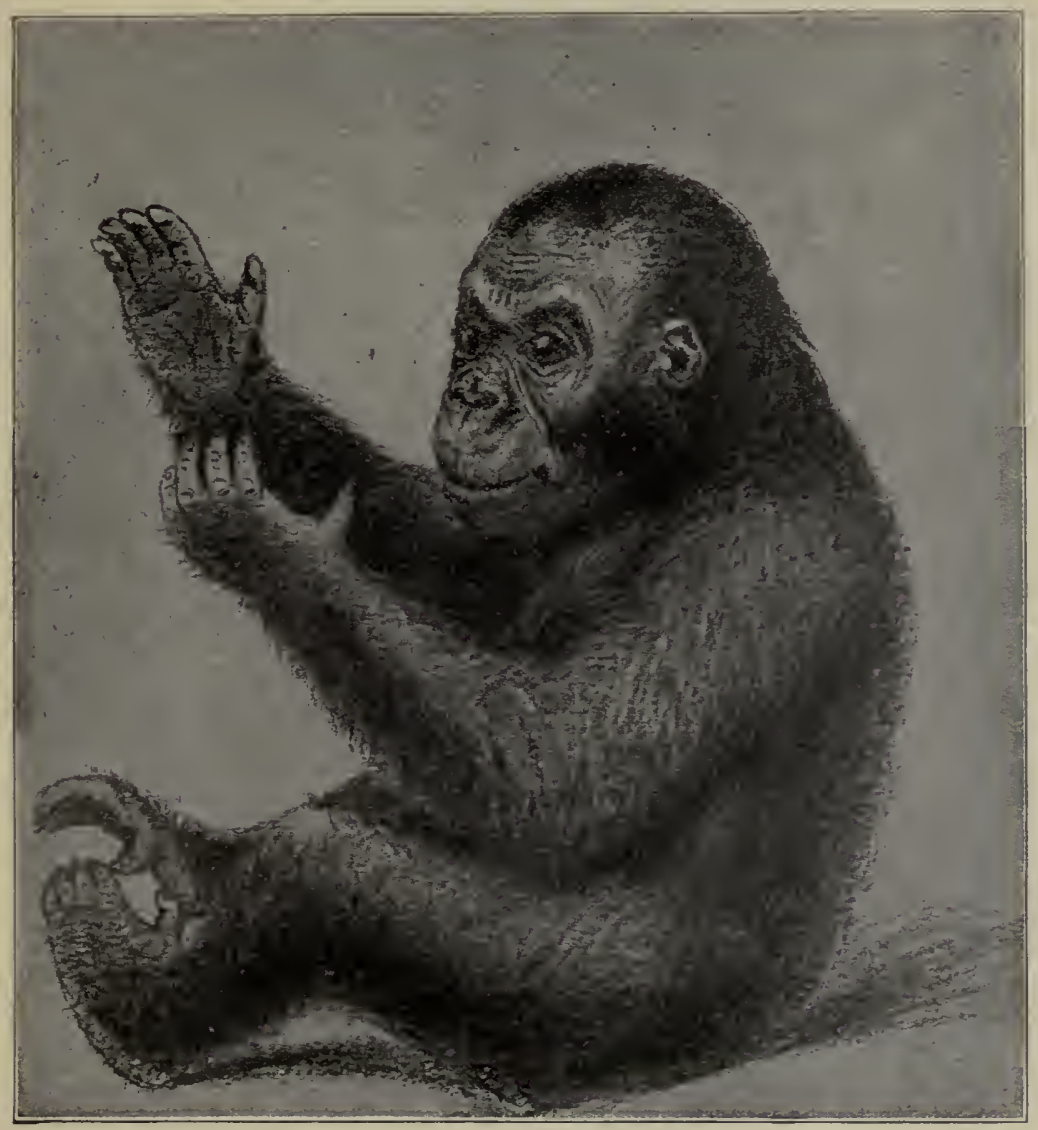

Young gorilla of the Leipsic zoological Gardens.

(From the Illustrirte Zeitung, October I9, 1905)

with a lake and within this lake there was another island on which wild people were living. The majority of them seemed to be women with hairy bodies, and our interpreter called them gorillas. We could not catch any of 
the males when we gave pursuit. They escaped easily because they climbed over gorges and defended themselves with rocks. We caught the females but we could not take them with us because they bit and scratched. So we were obliged to kill them. We skinned them and sent their hides to Carthage."

Pliny, referring to Hanno's account mentions that these skins were still extant in his time and were preserved in the temple of Juno, which we must assume to be the temple of Istar.
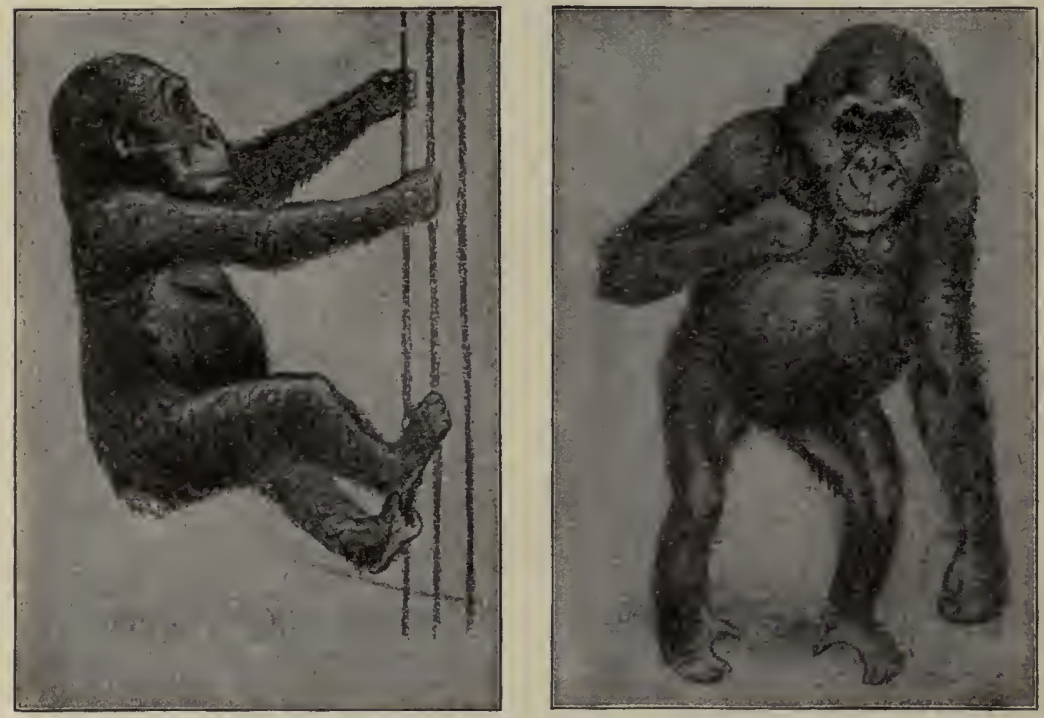

TWO POSTURES OF THE LEIPSIC GORILLA.

3934

(From the Illustrirte Zeitung, October 19, 1905.)

Dr. Brehm has a great deal to say about the gorilla. He quotes from Wilson, Ford, Du Chaillu, Reade and others, among whom Du Chaillu's accounts are perhaps the most interesting, but must be used with care as they are uncritical and ostensibly written more for the purpose of entertainment than to give exact information. The description of his first encounter with a gorilla is very graphic. This native of the forest had been creeping 


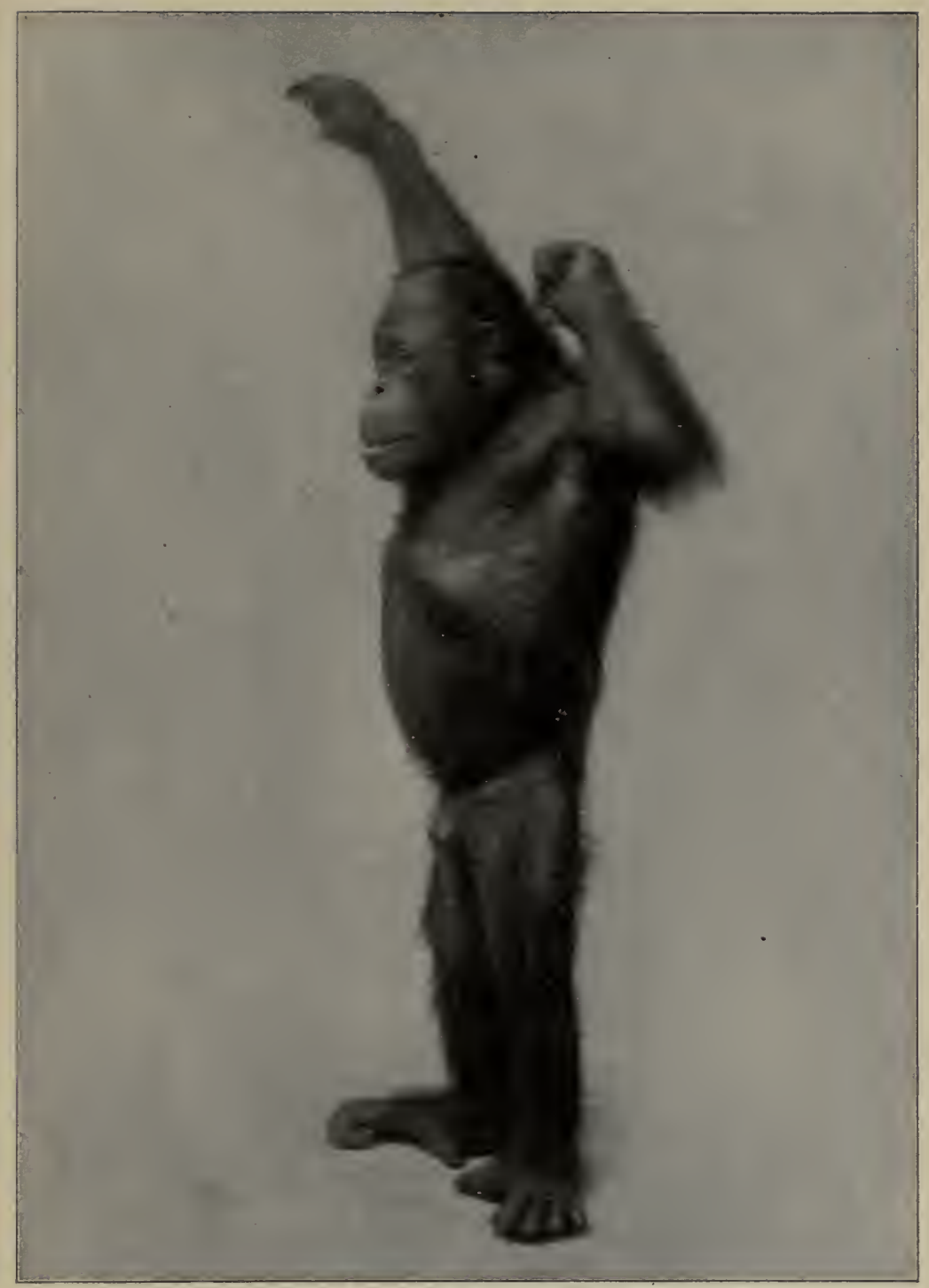

Plate III. Orang-Utan Distinguished for his Erect Walk.

This orang-utan is about four years old, and Mr. Edwards believes that he was caught when very young and must have been a household pet in a native family in the Malay Archipelago where he was a playmate of the children from whom he acquired at a tender age some human habits, especially his erect posture which is unusually straight and which he can keep up longer than any other simian. 


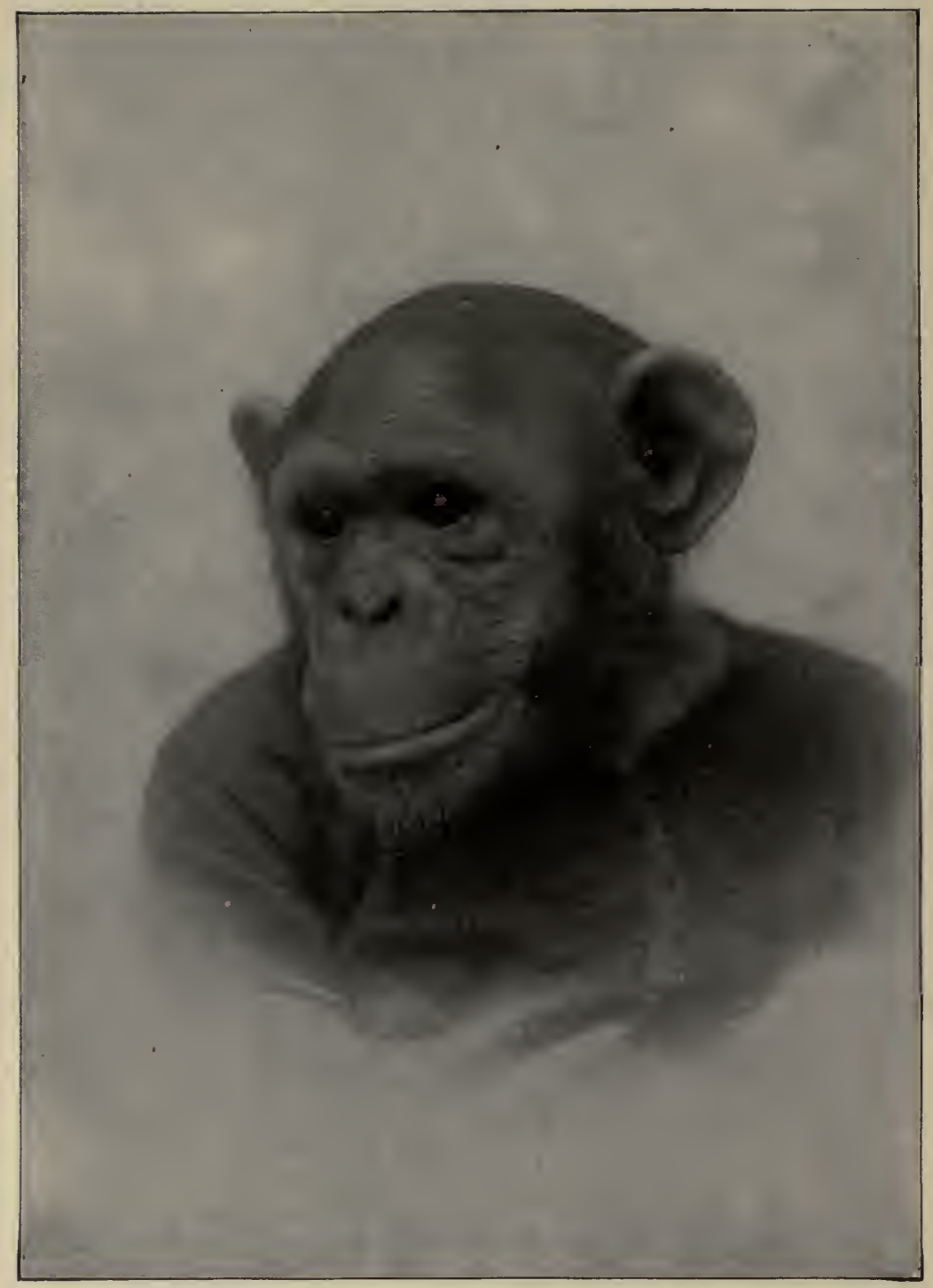

Plate IV. Joe the Chimpanzee.

A distinguished member of the Edwards' Zoological Exhibition. Mr. J. S. Edwards writes that this photograph is of a male chimpanzee, about six years old, and the most intelligent animal he has ever owned. Joe always wears a sweater, and when enjoying himself in play his laugh sounds more human than that of any other ape. In his actions he is very like a child and suggests at once a relationship to homo sapiens. 
through the underbrush, but when he discovered the party of hunters, he stood bolt upright and fearlessly met their eyes. There he stood at a distance of about thirty feet and without the slightest indication of fear struck his breast with his powerful fists so that it resounded like a metal drum. That was his signal of defiance and challenge, and between its repetitions he would utter such a roar that it might be considered the most peculiarly distinctive and frightful sound of the African forests. It began with a bark like that of a large dog, but ended in peals like distant thunder. The hunting party stood motionless on their guard, while the animal's eyes gleamed more fiercely, the tuft of hair on his forehead alternately rose and fell, and he showed his terrible fangs. As he came nearer step by step with his defiant gesture and roar, the explorer says he looked like the creatures, half man and half beast, which old masters used in representing the inhabitants of hell. When he came to within twelve or fifteen feet the hunters fired and the victim fell with an almost human groan.

The Zoological Gardens in Leipsic boast at present of a young gorilla bought by Herr Pinkard in London, and the young anthropoid has so far enjoyed good health in his northern climate. Judging from the experiences we have of other anthropoid apes, it is scarcely probable that he will live to a good old age for all of them have died prematurely of consumption. An artist of the Illustrirte Zeitung, Hermann Schüssler, has drawn the interesting specimen in several characteristic attitudes, and we here reproduce some of his most satisfactory sketches.

$$
\text { * } \% \quad \%
$$

The chimpanzee, although considerably smaller than man, is perhaps nearest to him in organization. At any rate Professor Friedenthal proved their consanguinity. It is a well-known scientific fact that the serum of the 
blood of one animal is poison when injected into the arteries of another individual of a different genus, because red blood corpuscles dissolve in strange serum. Professor Friedenthal has proved, however, that kindred species will not suffer greatly by an interchange of serum; for while the interchange of the serum of a cat and a rabbit would be destructive to the life of either, in the case of the horse and the ass, or the dog and the wolf, the results are not fatal. In view of these facts it is of great interest to learn from his experiments that man and chimpanzee possess blood that can be similarly interchanged.

Chimpanzees live in herds, and a company of them gives the impression of a jolly frolicking party of children dressed up as satyrs or fauns. They inhabit the tropic parts of Africa. Besides being literally kin of blood to man, the chimpanzee among all of the primates is the only ape that possesses an indication of lips. Man is the only animal that is in possession of two lips. All the monkeys have a sharp mouth without the gentle curvature which is so expressive in the human face. The chimpanzee's mouth, too, is sharply cut off, but the margins are at least slightly pink in color, while those of the gorilla and the orang-utan are as dark as the snouts of lower beasts.

The chimpanzee is smaller and more slender and graceful than the gorilla. He is not so strong, but far more intelligent. By nature he is a strict vegetarian; but in captivity he learns to take flesh and broth. As soon as accustomed to it he even enjoys and prefers meat to his former diet. Of one chimpanzee, who was brought up in captivity, we are told that at first he refused meat, but by and by he became accustomed to it and soon took the same food as man.

Chimpanzees in captivity are easily accustomed to imitate human society. They sit at the table like men, use spoons and even knives and forks. They also are easily 


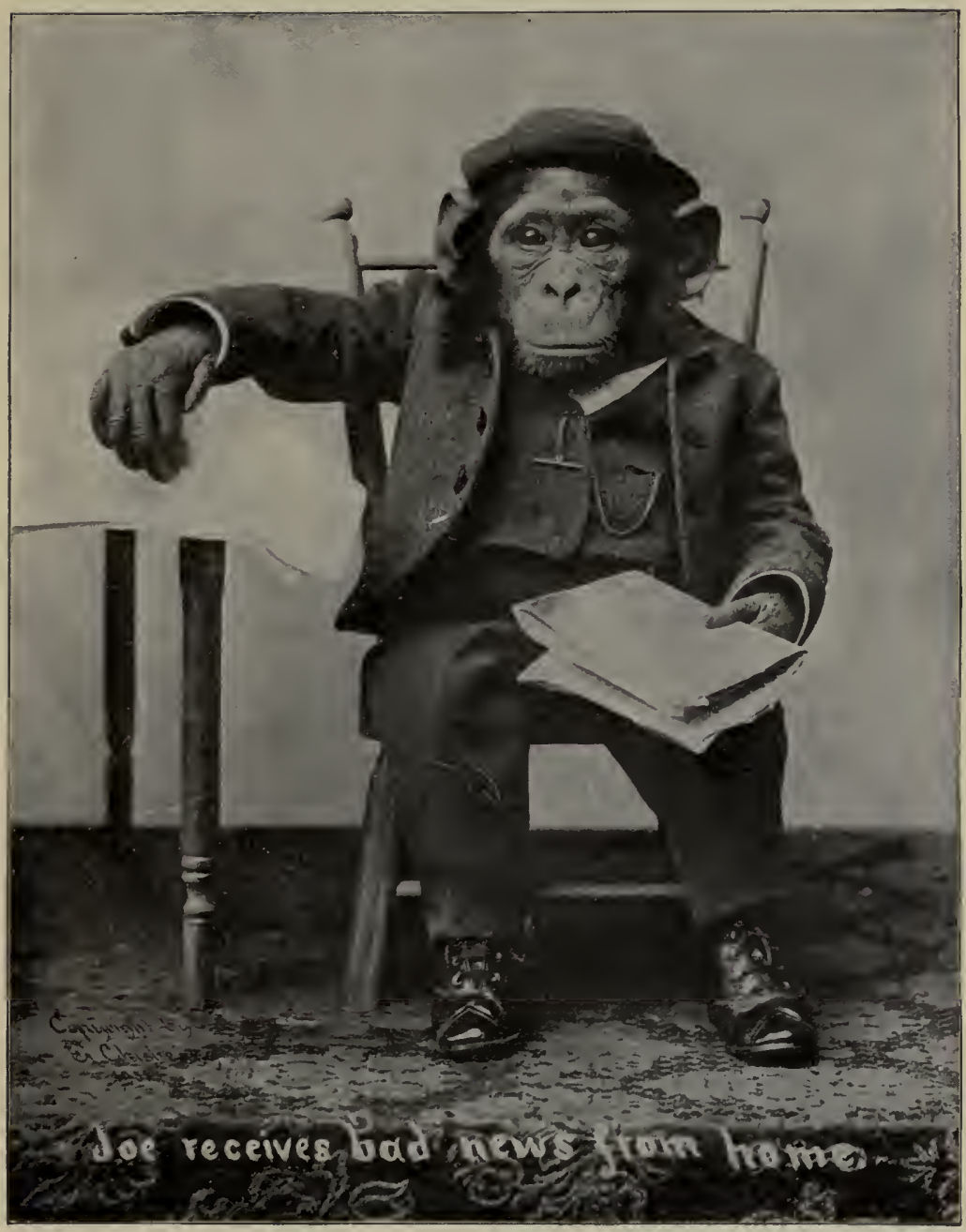

Plate V. Joe Receives Bad News from Home.

This is the same Joe that is represented in Plates IV and VI. His face plainly shows his disappointment. 


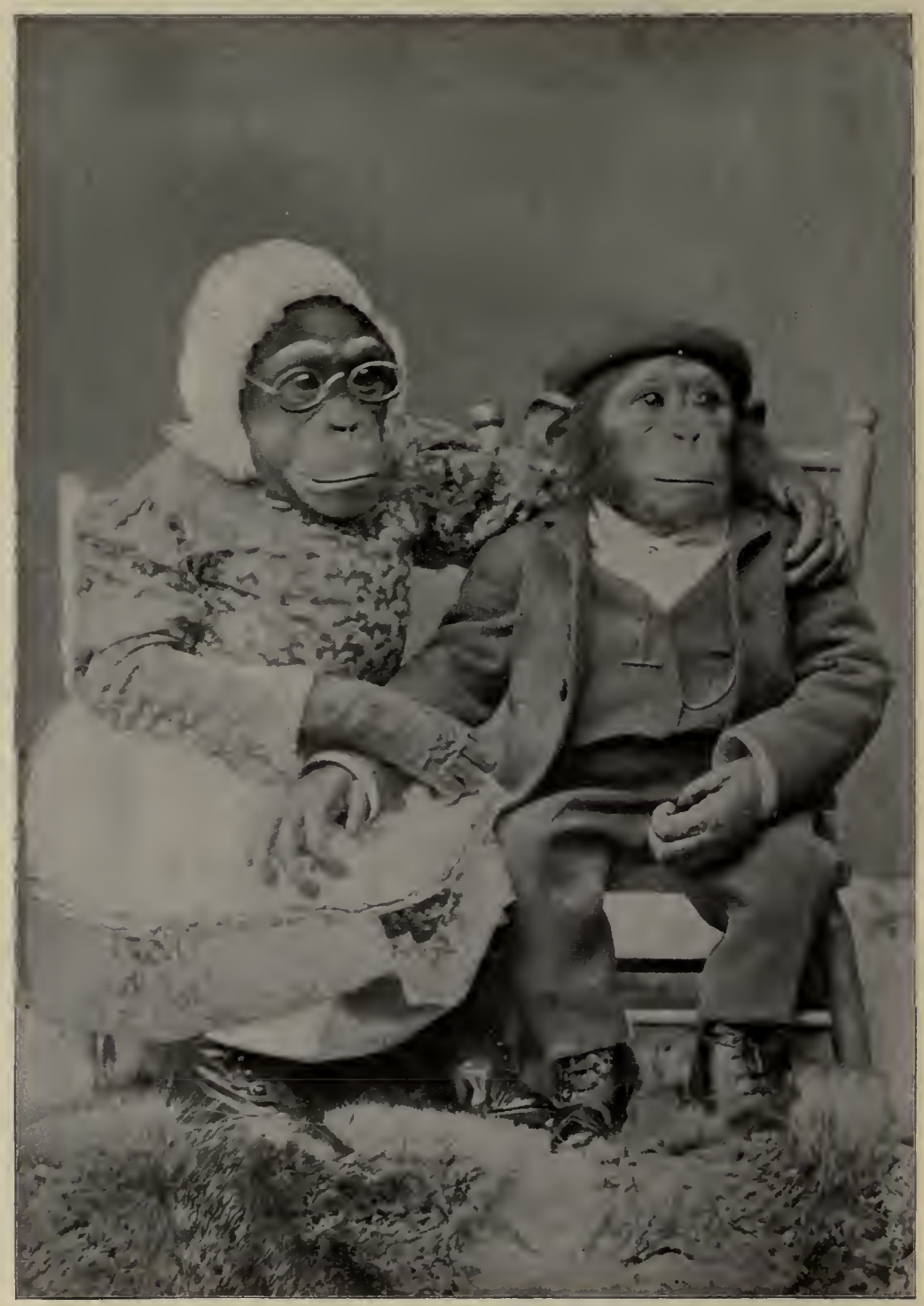

Plate Vi. Joe and Salite at Home. A Chimpanzee couple of Edwards' Zoological Exhibition. 
accustomed to alcoholic drinks and exhibit the same symptoms as man if they take too much. We are told that once a mirror was handed to a chimpanzee who appeared suddenly as if struck with awe. After a state of greatest agility he became extremely thoughtful. He looked up to his trainer as if questioning him as to what the strange object could be. He then investigated the mirror, touched it with his hands, looked behind it, and behaved

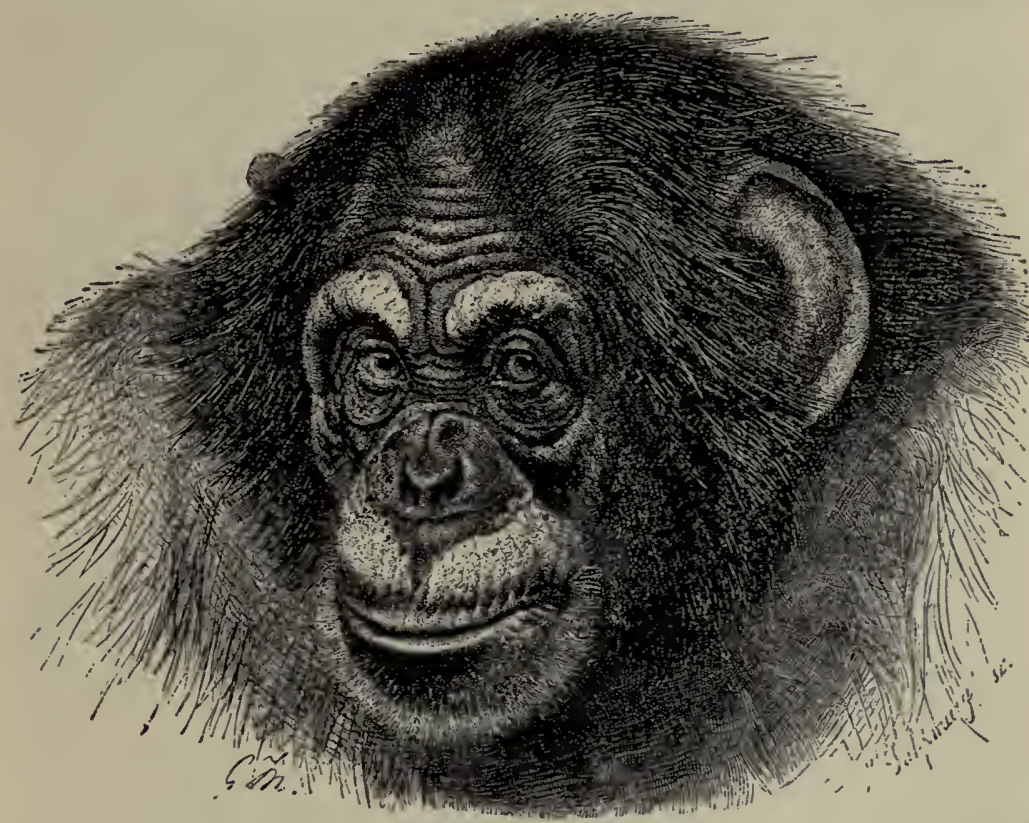

Chimpanzee.

(Brehm's Thierleben, I, 68.)

in quite the same manner as do savages when they see reflected pictures in a mirror for the first time.

The natives of Africa agree in regarding the anthropoid apes as a low class of human beings, and are firmly convinced that they only pretend not to be able to speak, for the purpose of shirking work. They say that if they were found out, many would certainly keep them as slaves and deprive them of their happy liberty in the forests. 


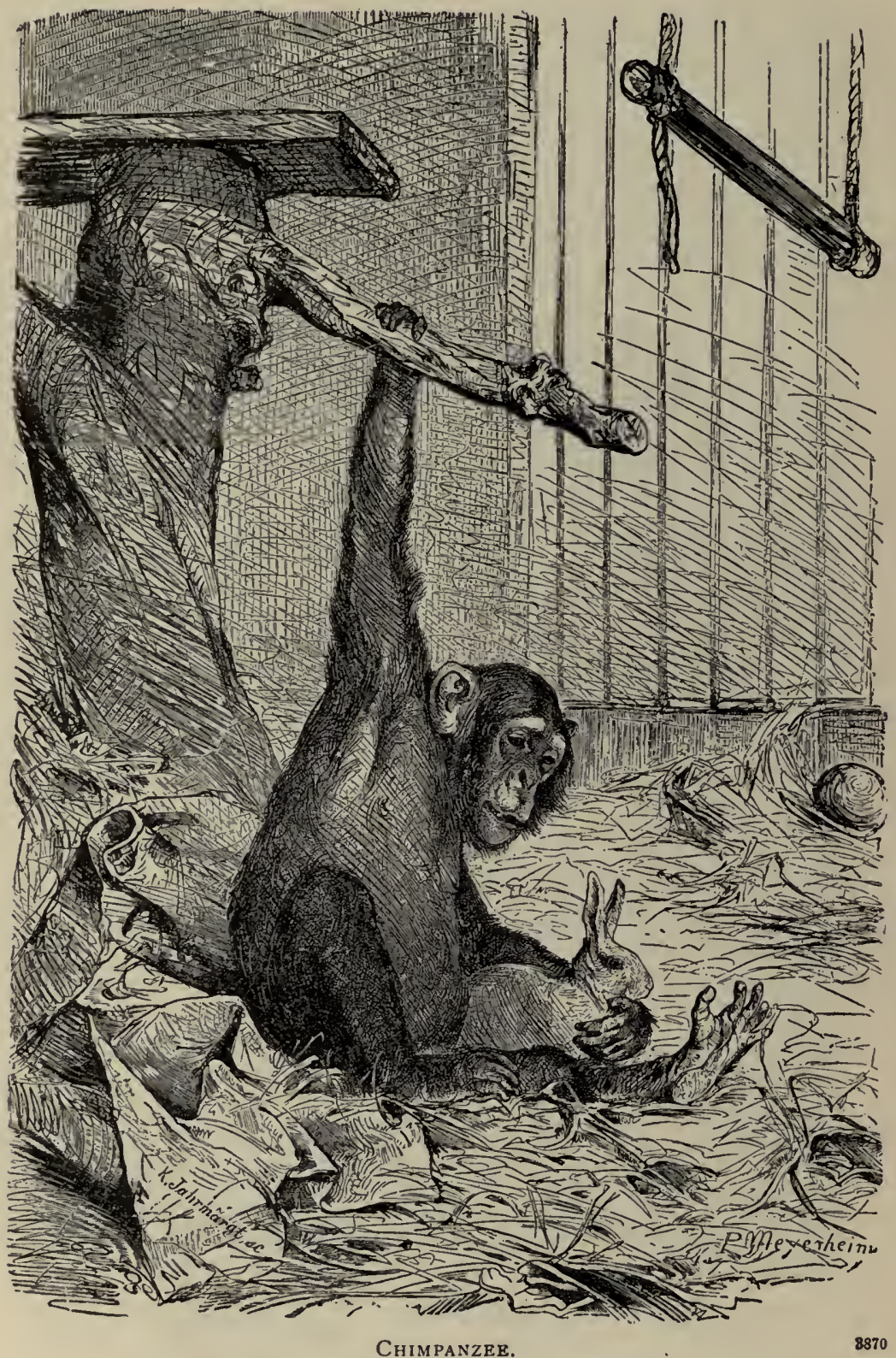

(Brehm's Thierleben, I, facing p. 68.) 
Most assuredly the anthropoid apes may seem happier abroad and certainly they are accustomed to their liberty. But it would be a grave mistake to think that they have

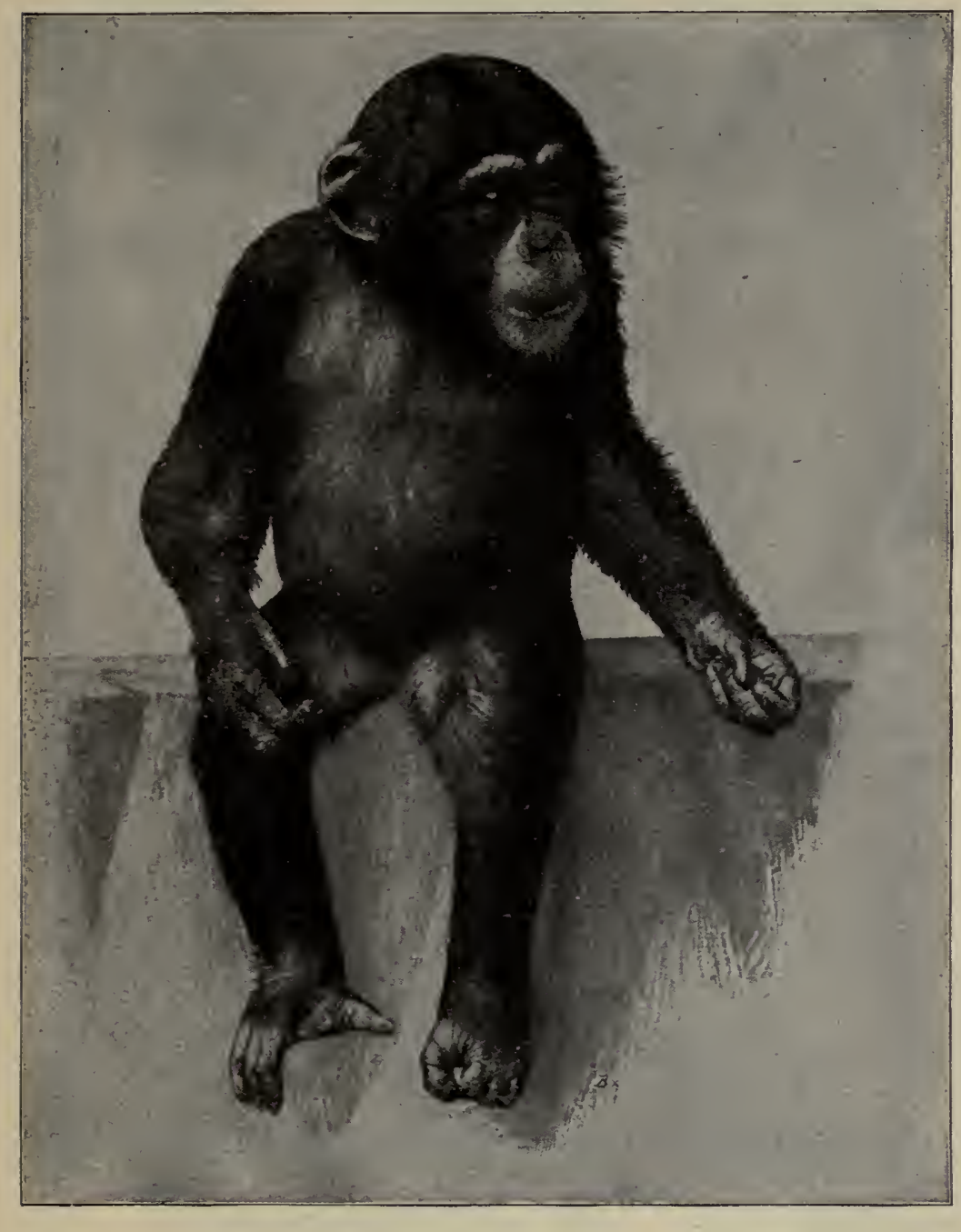

YOUNG CHIMPANZEE.

8868

Photograph from life by Dr. Heck of Berlin. (Weltall u. Menschheit, II, I7I.)

an easy and pleasant life. They have to make their living as much as any other animal, and it appears that they 


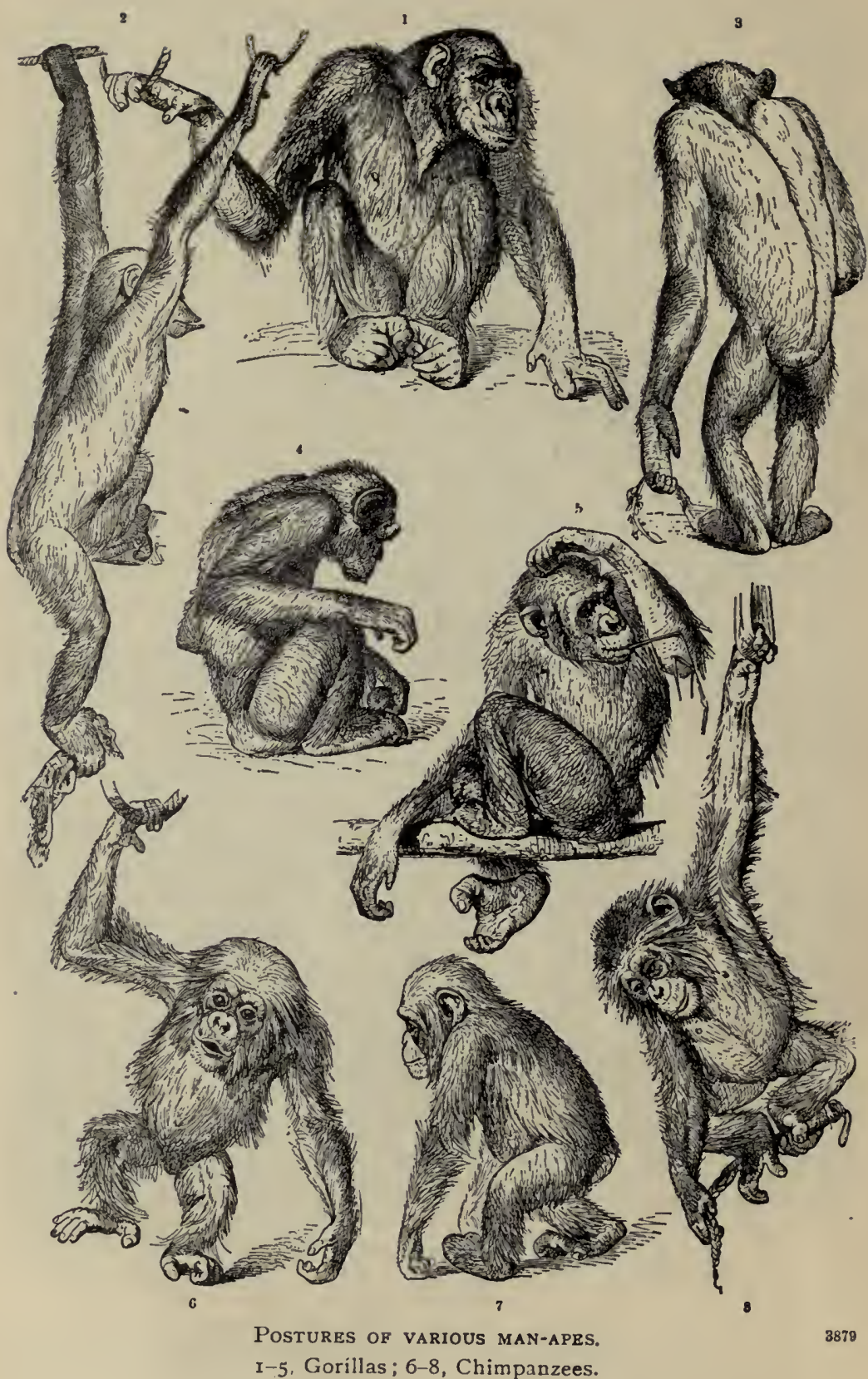



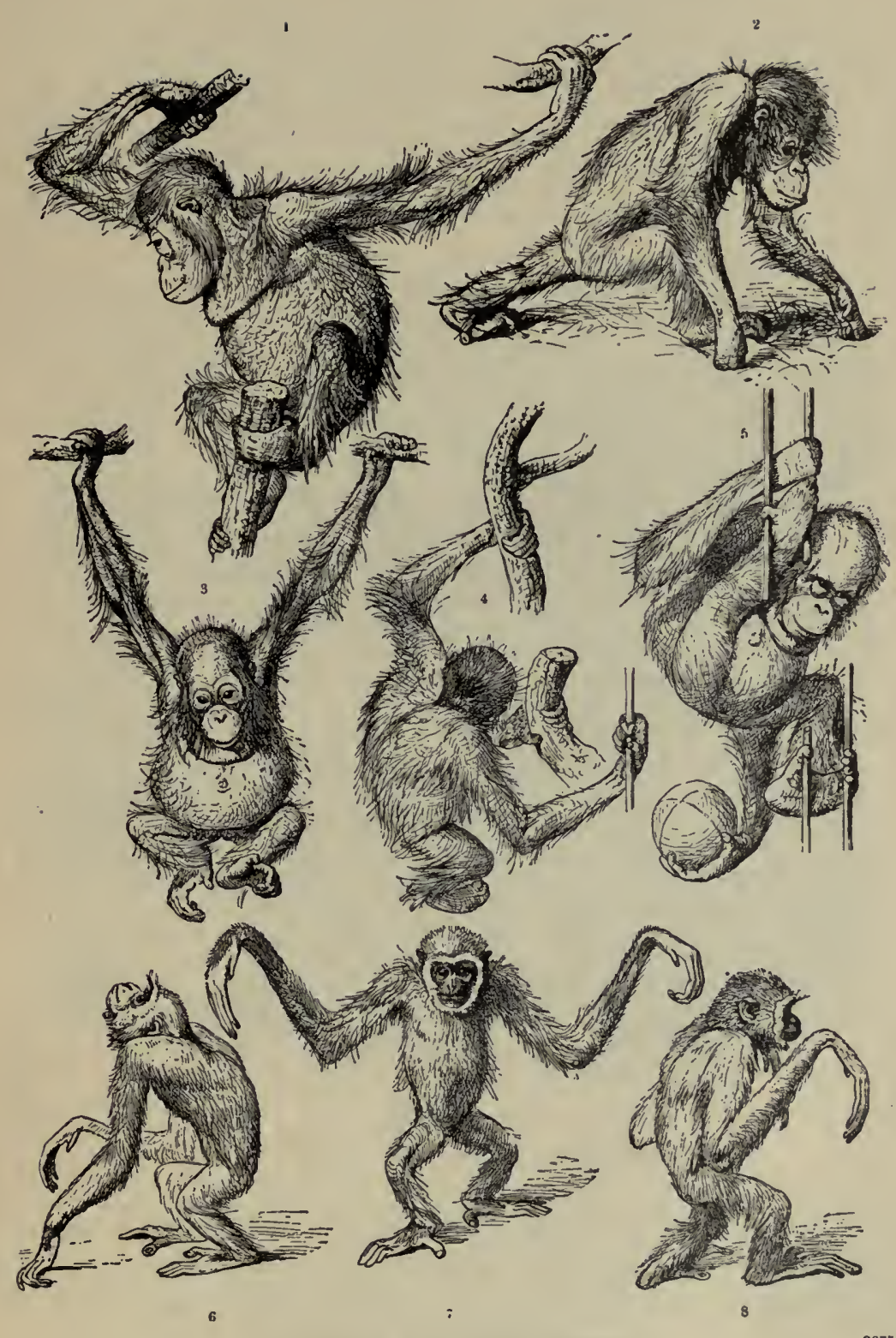

Postures of Various MaN-APES.

I-5, Orang-utans; 6-8, Gibbons. 
have a very hard time of it. Being vegetarians they need a greater mass of food than if they were carnivorous, and it is not impossible that the man-ape who rose to the higher existence of an ape-man and finally to that of man, had one great advantage over his less fortunate cousins by changing his diet. The anthropoid apes have to put

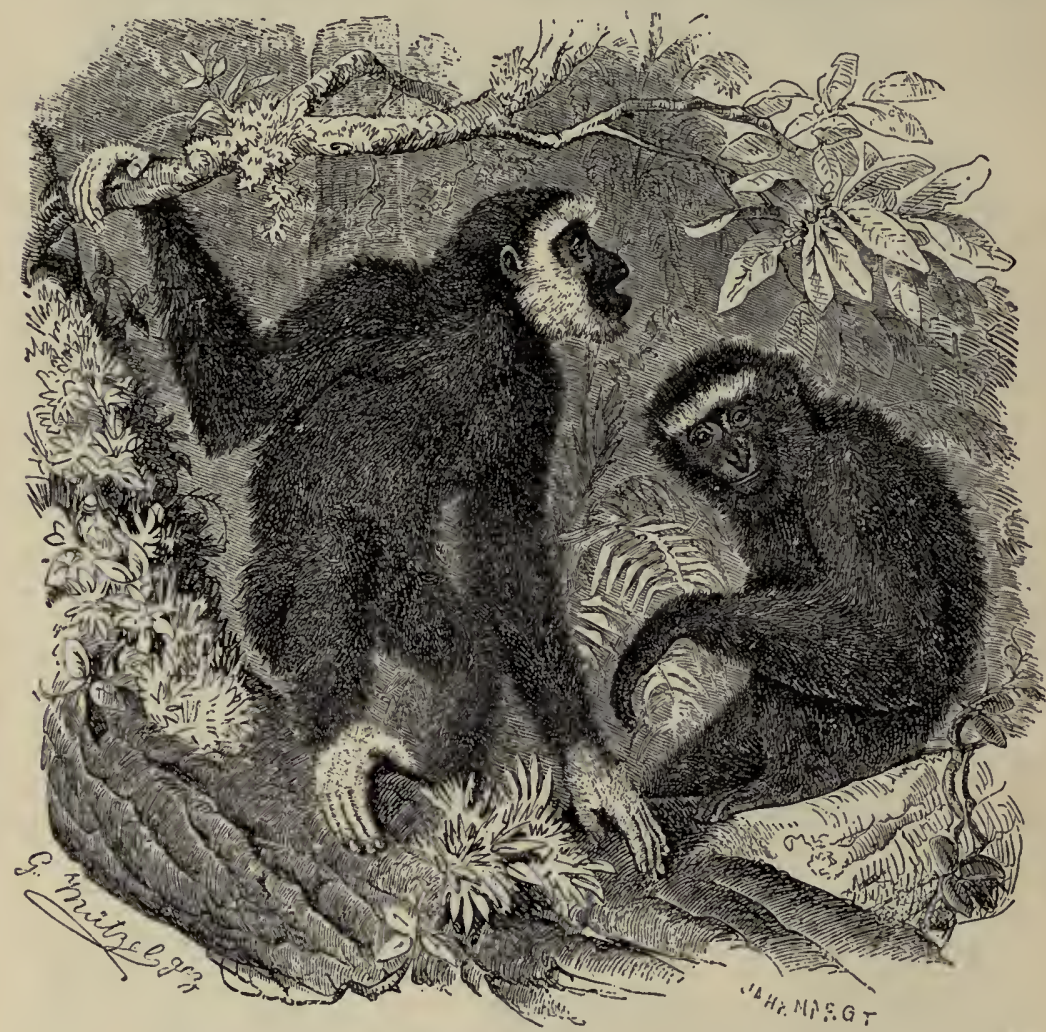

LAR AND HULOCK.

After Hanhart. (Brehm's Thierleben, I, p. 94.)

in all their time in hunting for food and eating it, while the omnivorous ape-man gained more leisure and moreover had his wits sharpened by becoming a hunter.

$$
\text { * * * }
$$

To the anthropologist the lower apes are less interesting, but we may mention especially the long-armed 
monkeys or hylobates, among whom the gibbon is perhaps the most noteworthy. Others of interest on account of their quaint appearance and habits are the hulock and the proboscis-monkey. The latter does not range very high, but should be mentioned in this connection on account of the human appearance of his profile, due solely to the development of his nose which however might rather be

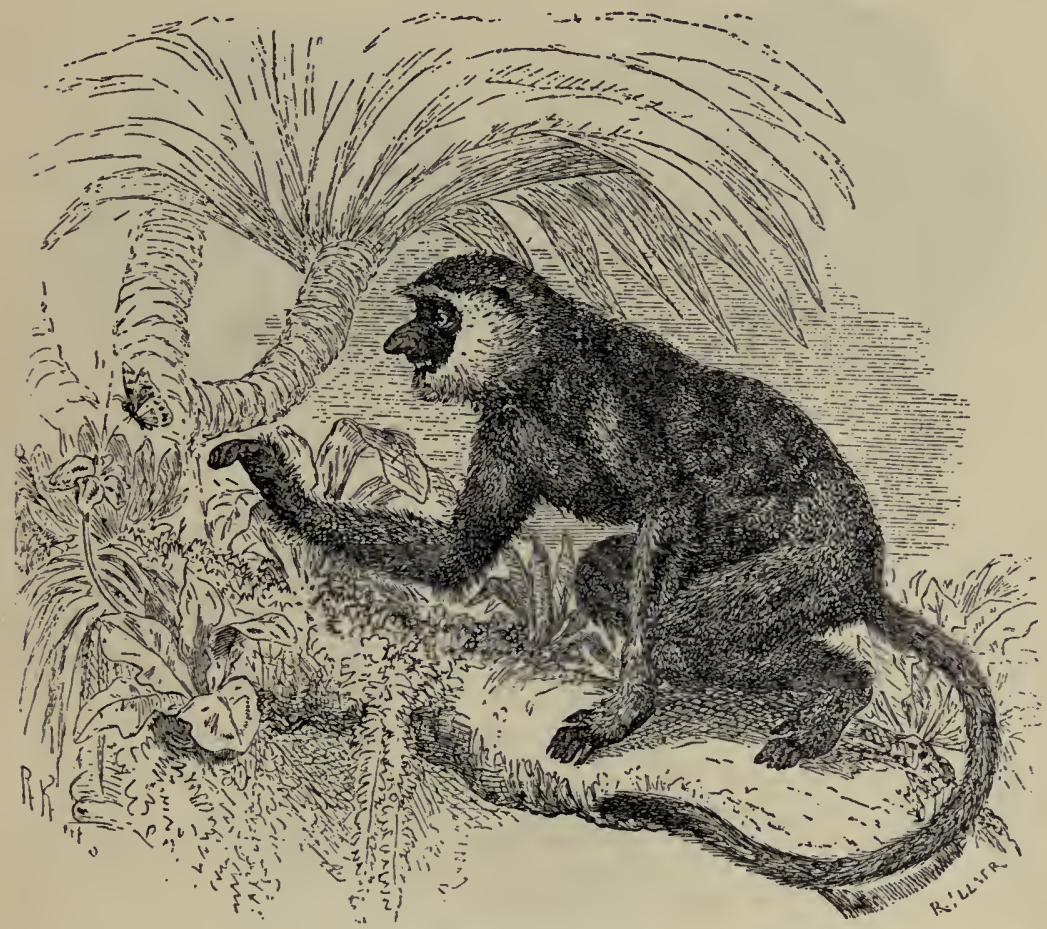

PROBOSCIS MONKEY.

(Brehm's Thierleben, I, p. Iro.)

called a proboscis. His similarity to man is more apparent than real, for his nose unlike that of man is movable; it can be pushed out and pulled back, but if extended to its full length, it closely resembles a very strongly developed aquiline nose.

One important similarity between man and ape is the development of the teeth. Both have 8 incisors, 4 canine 
teeth and 20 molars; yet it is well known that in the higher races, the hindmost molars grow at a mature age and are generally subject to early decay. It seems as if the development of the brain implied a decrease in the organs of mastication. The jaw bones grow smaller and the facial angle approaches more and more nearly to $90^{\circ}$. The similarity between human and Simian teeth, how-

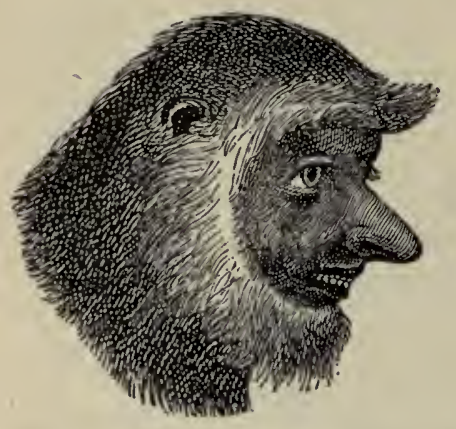

3895

HEAD OF PROBOSCIS MONKEY.

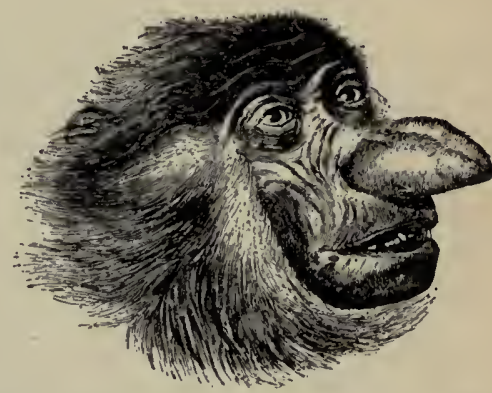

3888
After Brehm.

(Haeckel's Anthropogenie, p. 607.)
After Wiedersheim.

(Weltall und Menschheit, II, 145.)

ever, is limited to the apes of the old world. Those of America possess thirty-six teeth in all, and preserve more the features of the lower mammals in this as well as in other particulars. Their noses, too, are turned upward, while the noses of the Old World apes all go downward. Hence their name, Catarrhines, derived from the Greek katá "downward," and rhinós, "nose." 


\section{PRIMITIVE MAN.}

THERE has been much discussion concerning the locality where man first originated, and the common opinion among a great many naturalists points towards the sunken continent in the Indian Ocean. It seems to have included Australia in the east and covered the Sunda Islands reaching to Madagascar on the West. Presumably it connected Asia and Africa with New Zealand. It has been called Lemuria as the supposed home of the Lemurian or monkey tribe.

We will let the theory pass as probable, although we think that it will be difficult to designate any definite locality as the place of the origin of man, for it seems that a change of surroundings may repeatedly have taken place and this would have favored a higher development, new conditions demanding new adaptations and eliciting thereby new faculties. Lemuria must have been large enough and its geography varied enough to have been a territory in which the first man-ape could have appeared, while the higher development of the race seems to have taken place farther north in Central Europe.

The human race, though still in a very brutish condition, must have existed in the Antarctic Continent or Lemuria before the separation of Australia from Asia. In the Museum at Sidney there is a slab containing imprints of human feet which according to Professor Klaatsch's opinion bear all evidences of having been made by primitive man. A sandstone ledge of the same 
formation shows traces of a bird long since extinct. The same anthropologist has found in his recent trip to Warnambool, in the state of Victoria in Australia, a great number of stone tools and implements, human and animal fossils dating back to the paleolithic period.

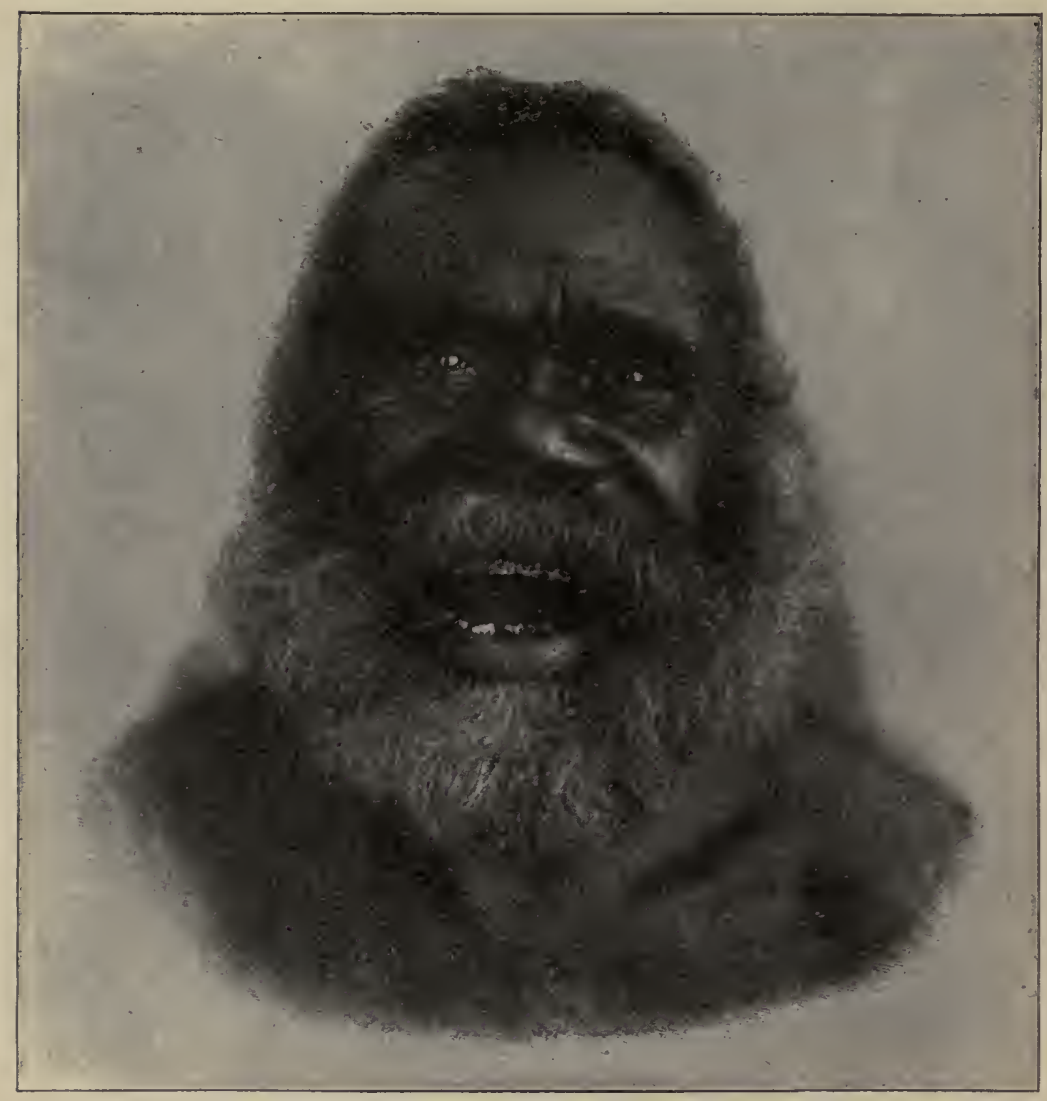

Type of an aboriginal Australian.

After a photograph. (IVellall und Mcnschheit, II, 315.)

It has been pointed out that Australia is a unique and isolated continent which harbors a number of intermediate species. It contained the lowest known human race which, however, has died out since the arrival of the white man. The wild dog called dingo, the duckbill, the kangaroo and 
other marsupialians are living there now. Man and dingo are the only creatures who represent the higher mammals, and we may therefore assume that they are late arrivals. The Australian race was the lowest of all known mankind, ranging even beneath the African negro. While not very ferocious they possessed scarcely any civilization and belonged still to the paleolithic period. They did not yet understand how to polish stones, nor to make the simplest kind of pottery.

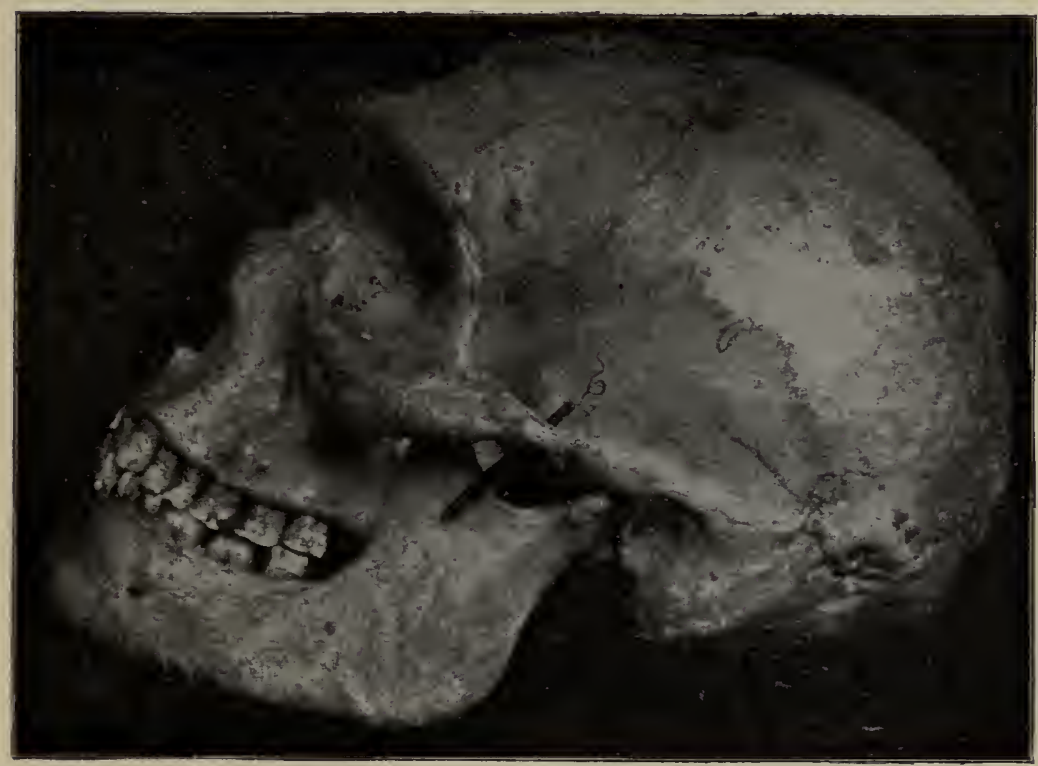

Skull of Aboriginal Australian.

Showing the protruding brows. After the original in the Museum of Ethnology in Leipsic. (Weltall und Menschheit, II, 337.)

Dr. Schötensack of Heidelberg, who assumes that mankind originated in or near the Indo-Australian Archipelago, claims that the Antarctic continent fullfilled all conditions for the development of the human race from lower forms. There were no beasts of prey to contend with, and man had there a chance to develop his type without let or hindrance. There were plenty of herbiv- 
orous animals of low intelligence which invited him to develop into a hunter and to change his nature into that of an omnivorous which distinguishes man from the apes. The country is partly wooded and partly prairie-land and so encouraged the upright walk. The hollow trees contained plenty of honey, and the Australian bee lacks a sting. It is further peculiar that the dog, at all times closely allied to man, was his only companion on the Australian continent.

While favorable conditions are often productive of

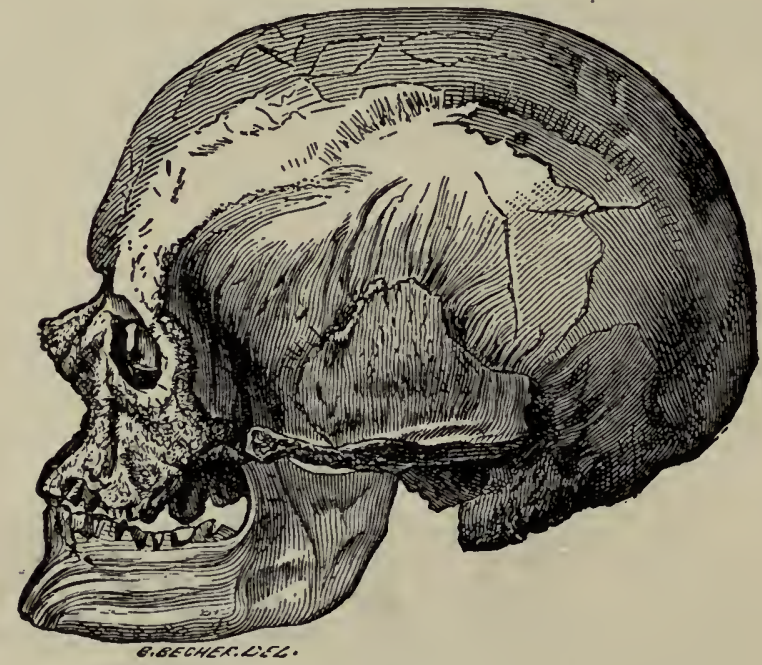

Old Man's Skull found at Cro-magnon.

After Broca's Conférence sur les Troglodytes de la Vezire. (Lenormant's IIistoire ancienne de l'orient, I, 145.)

good results, we would point out that the highest development is generally not obtained by them alone, but by a change from favorable to unfavorable. Favorable conditions develop new varieties with certain free exuberance, and give them a chance to establish new qualities, while unfavorable conditions put individuals to the test and select those that are fittest to survive. While the lower type of mankind (the man-ape) appears to have been developed in a Southern climate, it seems almost certain 
that a selection of the fittest has been made in the rougher regions of the north, and this supposition seems to be borne out by the fact that so far decidedly all the higher types of primitive man have been discovered in central Europe, while of the very lowest there are not a few (viz., the Neanderthal man and those represented by the relics of Spy and Krapina) that find a most primitive counterpart only in the relics of the ape-man of Java discovered by Professor Du Bois, called pithecus anthropus erectus Du Bois.

Progress in our days is not made because man likes

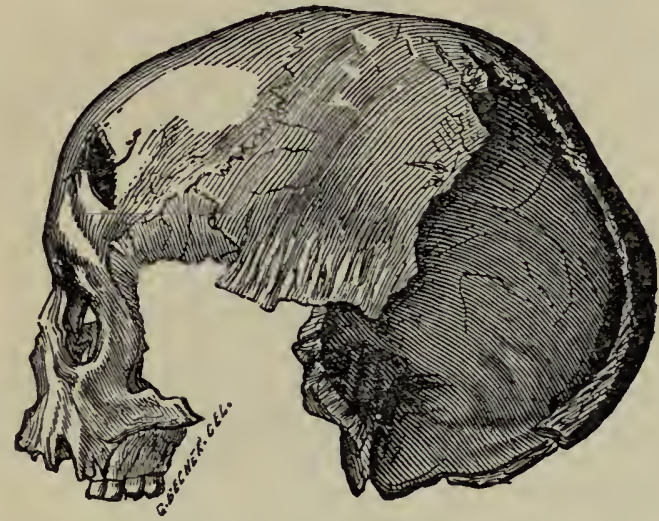

Woman's skull found at Cro-magnon.

From the same source as the preceding illustration.

to advance and learn new lessons, but mainly because he must progress and discover. Man must make new inventions because competition and the struggle for life force him to do better than others and rise higher. It is as if nature were whipping man onward and forward, and there are only a few individuals that have acquired a natural impulse to work, to advance, and to inquire. There are very few indeed that labor for the sake of progress and for the love of it.

We may assume with great probability that the most important step taken by life in its higher advance, 
viz., in its transition from a primitive existence to a social and more truly human existence, was done under compulsion and under the penalty of perdition for the unsuccessful. The rational being, called man, is probably the survivor only of a great number of man-apes that died out because they were unable to take the step and fulfil the stern demands made on them by circumstances.

The perfection of mankind, must most presumably be sought in the North, not in the South; in a place where life is hard, not where life is easy, and we may assume that by some catastrophe, a number of ape-man families were cut off from the sunny regions of the southern countries, and had to fight their way in a dreary northern climate, where they would unfailingly perish unless they acquired the necessary altruism to help one another, and the indispensable intelligence to protect themselves against the inclemencies of hostile conditions. 


\section{THE NEANDERTHAL MAN。}

T $\mathrm{N}$ the year 1857 a human skeleton was discovered in a Iimestone cave (commonly called the "little Feldhofner Grotto ") in the Neanderthal near Dornap, between Düsseldorf and Elberfeld. And how hot were the controversies about the character of the bones as well as the formation of the skull! Virchow, so liberal in politics

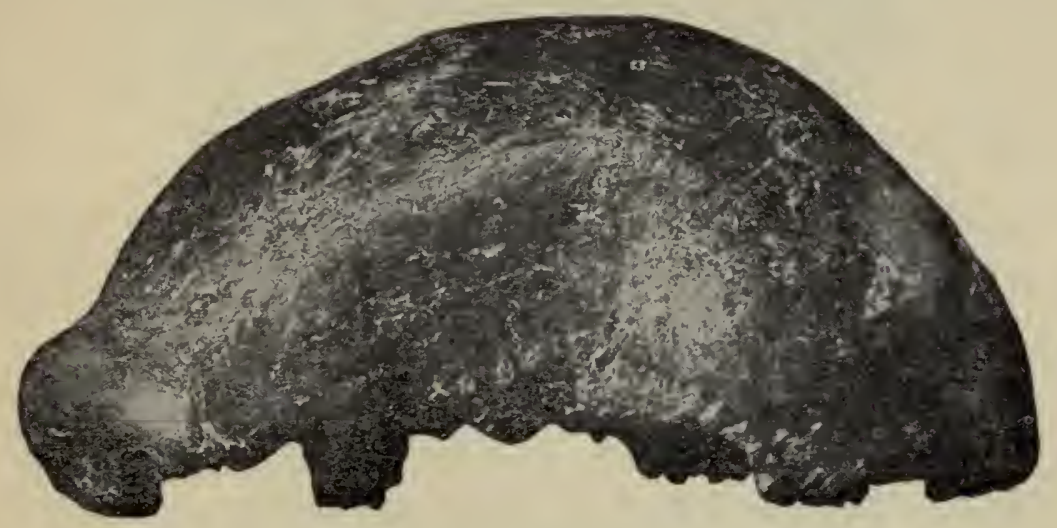

Lateral View of the Neanderthal Skull. After Schwalbe.

and reactionary in science, advised caution and declared that these bones might be the remains of an imbecile and degenerate individual.

Professor Virchow claimed that no conclusion could be drawn from one isolated instance; but in the meantime other skeletons and skulls of a similar type have been discovered, which prove that the Neanderthal man was 
not an isolated individual, but the representative of a race that must have inhabited the caves of Europe at the time when mankind had just risen into existence. The skulls of Egisheim, of Brux, and of Cannstatt, all characterized by an approach to the ape type, and two skeletons discovered by Messrs. Fraipont and Lhoest in 1897 near Spy, Belgium, belong also to a race that was not very distant from the Neanderthal man. The cave in which the latter

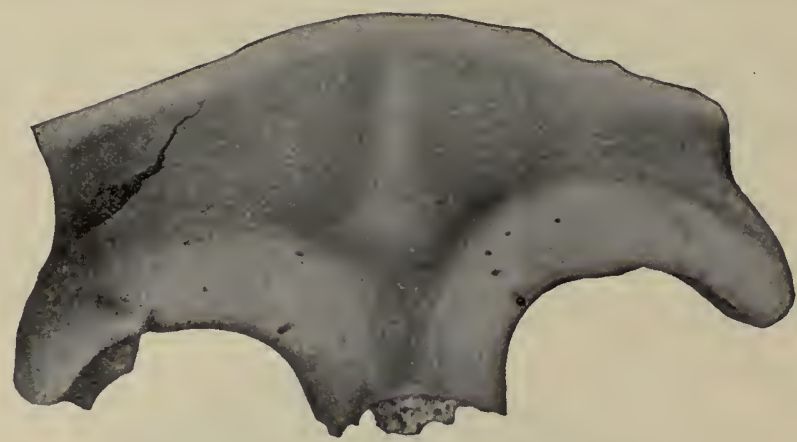

Front View of the Supraorbital Regron. ${ }^{1}$

After Schwalbe.

were found contains in the drift, flint implements of the crudest kind, and bones of the rhinoceros, the cave bear, the cave hyena, and other remnants of the earliest stone age. $^{2}$

Renewed investigations of the Neanderthal skull have justified the theory that it belongs to a primitive man. These new discoveries in connection with the renewed and careful investigations of the skull have dis-

1 The fracture in the right temporal region is plainly visible and is obviously due to a vigorous blow which, however, may have been made at the disinterment.

A groove is visible over the extreme part of the right eye, slanting over the supraorbital ridge, and ending in an incision. These marks bave been the object of much discussion. The incision appears to be the passage for the supraorbital nerve, for it has its analogon, although in a much weaker form, on the right side: but the depression appears on one side only, and thus it is possible that it is the result of an injury received and cicatrized during life. Some of the little holes can be definitely identified as passages for blood-vessels, and none of them seem to be caused by disease.

2 Prof. G. Schwalbe of the University of Strassburg in Alsace has devoted an especial monograph to the subject, which he has published in the Bonner Jahr. biicher, No. 106, pp. I-72, under the title "Der Neanderthalschädel." The article has also appeared in a special reprint. 
pelled all doubts concerning the nature of the Neanderthal remains. We may say without fear of contradiction that the discussion has passed the critical stage, and all anthropologists of reputation agree that we have here the specimen of a primitive race whose forehead still preserves the orbital ridges of lower animals, and the facial angle of which is considerably lower than that of the lowest negro type, being only slightly higher than that of anthropoid apes. The Neanderthal skull measures $62^{\circ}$, the

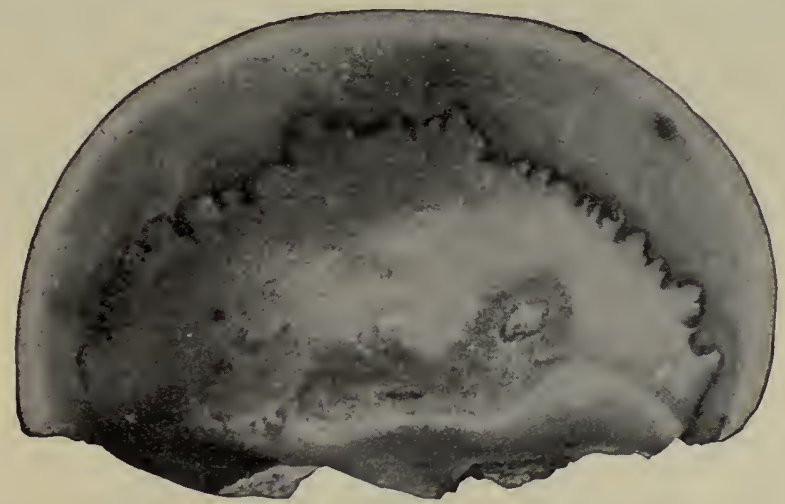

Occiput of the Neanderthal Skull. ${ }^{1}$

After Schwalbe.

two skeletons of Spy $57.5^{\circ}$ and $67^{\circ}$, while the highest apes reach $56^{\circ}$. The facial angle of the human race of to-day averages from $80^{\circ}$ to $85^{\circ}$.

While the forehead of the Neanderthal man is narrow and low, the occiput is well developed, and though judging from his bones he must have been a strong creature and presumably ferocious in fight, he may not have been lacking in kindly sentiments, as indicated by the width

1 On the right parietal bone we discover a cicatrized hole made by a pointed instrument, which looks, as Virchow says, as if it were made by a "bayonet," or "a sharp stone," or "any other pointed weapon," perhaps a lance, or an arrow. It was healed during the lifetime of our subject.

The occipital bone shows further a rough depression which Virchow suspected to be the result of a disease, but anatomists (among them Recklinghausen) declare that similar formations are not of unfrequent occurrence among normal skulls.

The linea nuchea suprema dextra is strongly marked. We notice further an unusual development of those parts from which the neck muscles originate. 


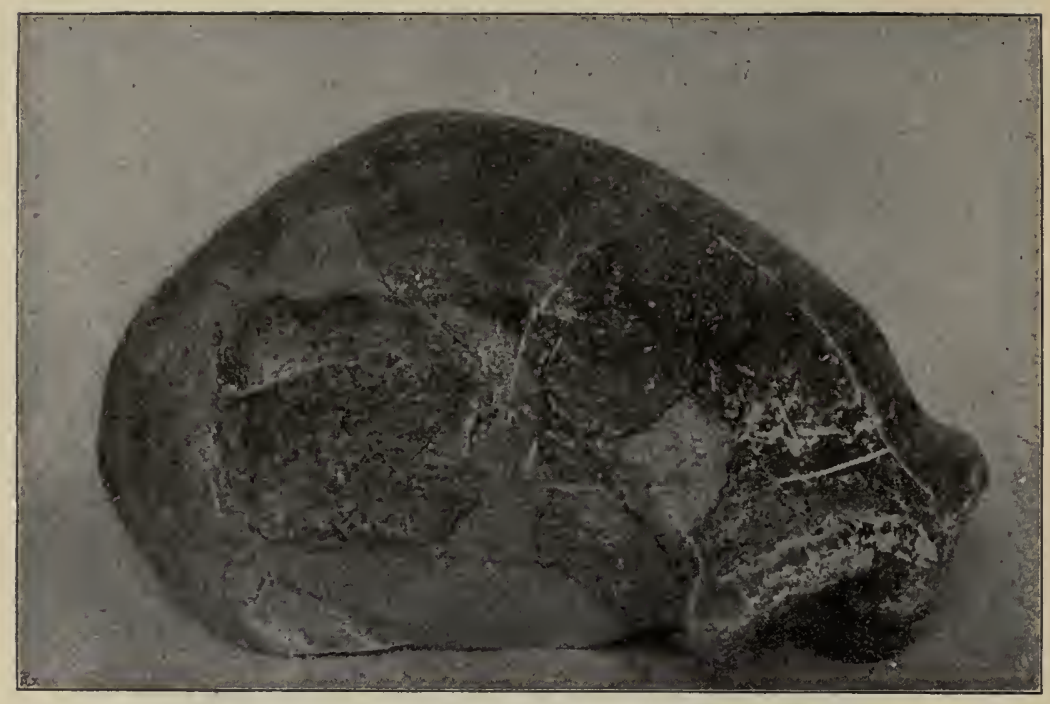

Cranium of the Primitive Man of Spy, Belgium. 3863 From a cast of the original in the Museum at Liège. (Weltall und Menschheit, II, 294.)

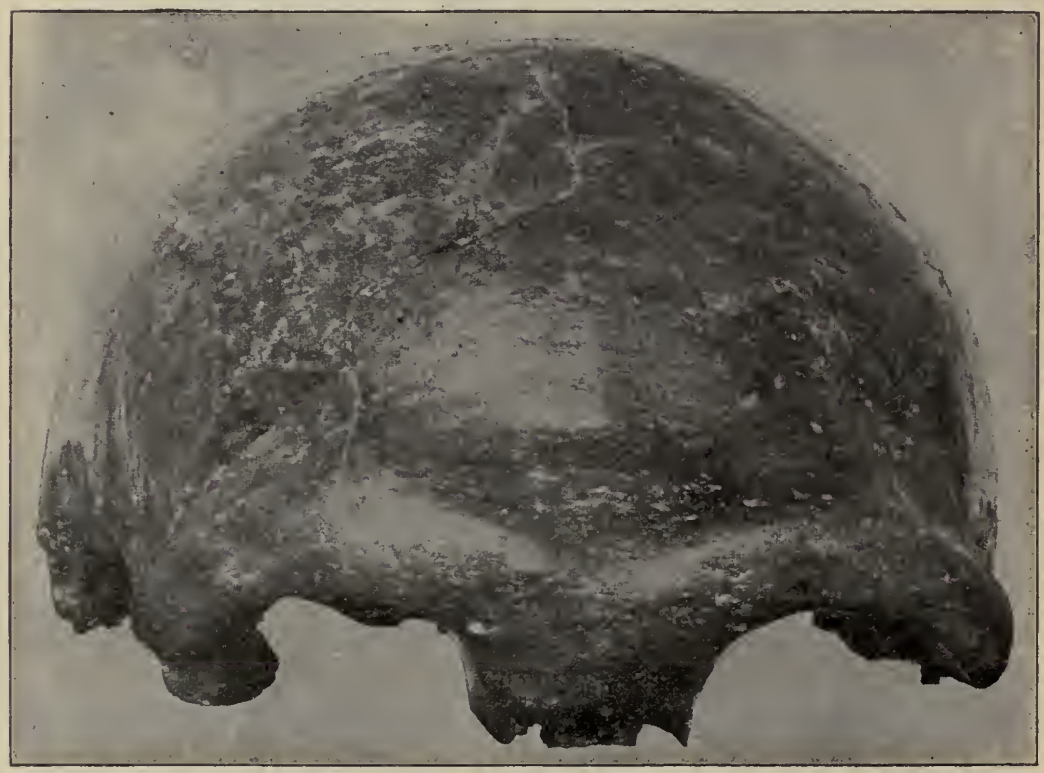

Cranium of the Neanderthal Man.

From the original in the Provincial Museum at Bonn. (Weltall und Menschheit, II, 20.) 
of his cranium. And what a story do the remains of the Neanderthal man tell! One ulna received an injury which was healed during the life time, but must have considerably hampered the use of his arm. The right parie-

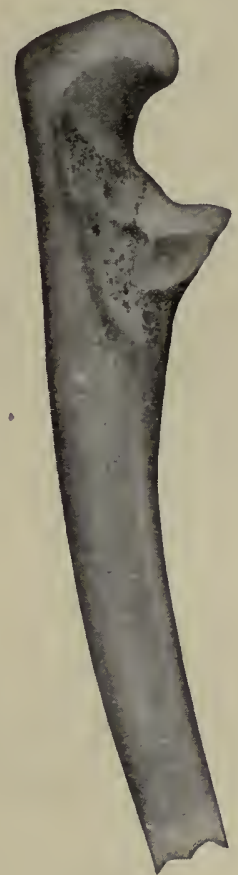

Right ULNA.

Normal.

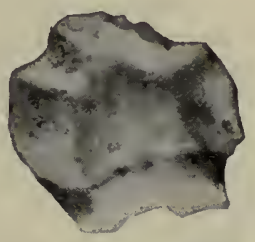

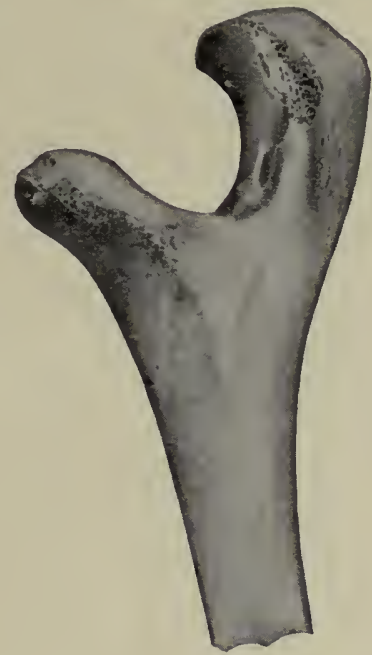

Left Ulna.

Pathological. ${ }^{1}$

tal bone of the skull shows the mark of a cicatrized injury which appears to have been made with a pointed weapon, an arrow or a lance. A furrow in the right superciliary ridge is another irregularity which seems to have been

1 The left ulna shows that the individual to which this bone belonged received a severe injury during lifetime the cure of which was left solely to nature. The rigbt ulna is normal and its surfaces of the processus coronoides are well preserved, but on the left ulna a fracture is visible. Here the incisura radialis is filled up with newly formed bone substance and thus brought this spot, destined to receive the capitulum radii, into direct contact with the humerus, the bone of the upper arm. The result must have been that the arm could not be fully extended.

Above the left ulna we reproduce the end view of the pathological processus coronoides. The cicatrized injury appears on the left side. 
caused by some violent blow and must have been an ugly gash over the right eye. Finally we notice a fracture

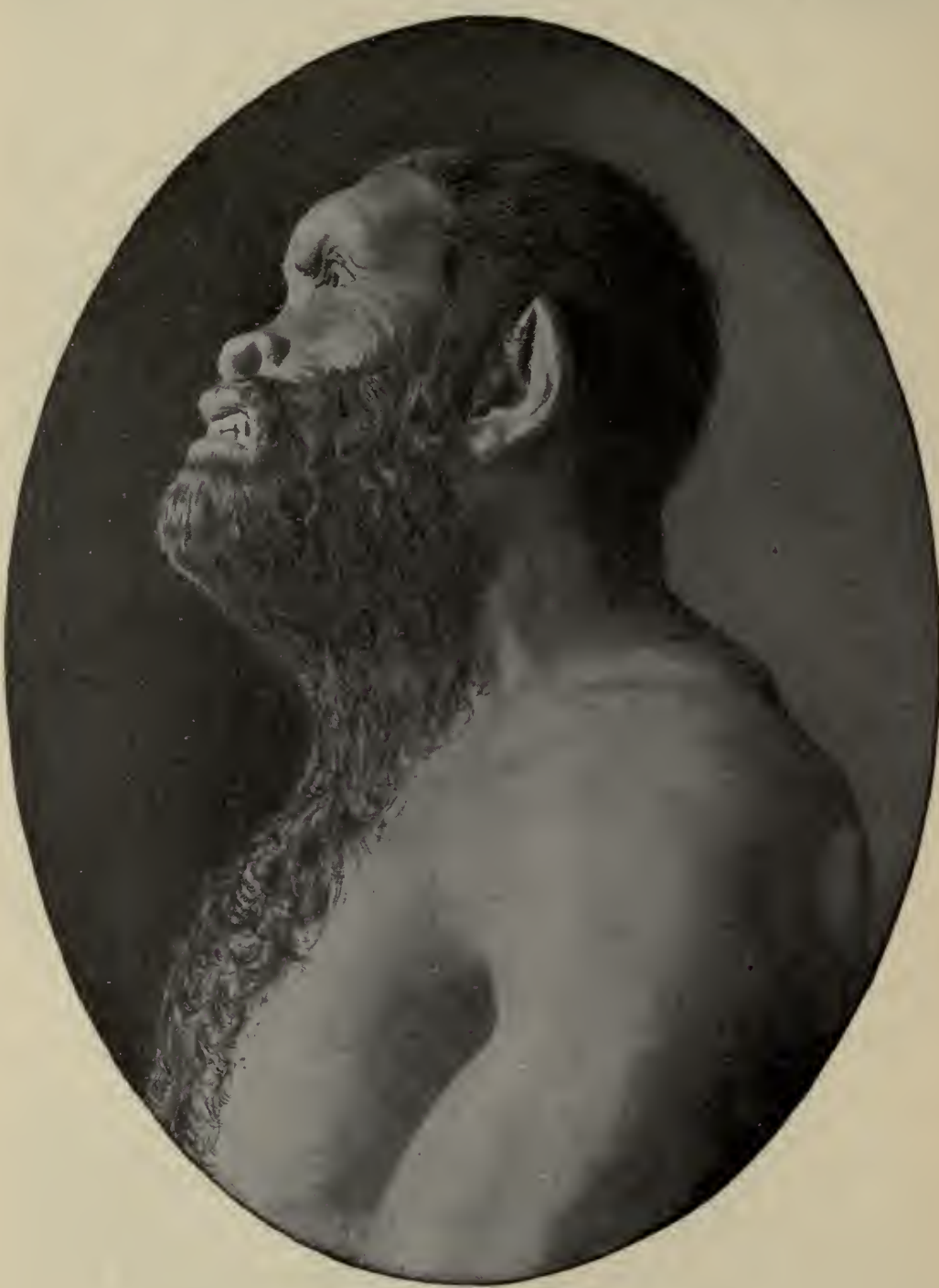

A Restoration of the Neanderthal Man. ${ }^{1}$

near the right temple which was presumably done by the spade of the laborer who unearthed these ancient bones.

1 This picture is a retouched photograph taken of a model made by Guernsey Mitchell according to the instructions of Prof. Henry A. Ward of Chicago. 
Otherwise it would justify the post-mortem statement of a violent death.

Accordingly the life of the Neanderthal man must have been one of fierce struggle either with rivals of his own type or with the cave bear and other ferocious beasts, perhaps with both, and finally he succumbed in the battle for life, perhaps also in a fight with his own or his tribe's enemies.

The pithecanthropoid whose remains were found in the Neander Valley, although no longer an isolated in-

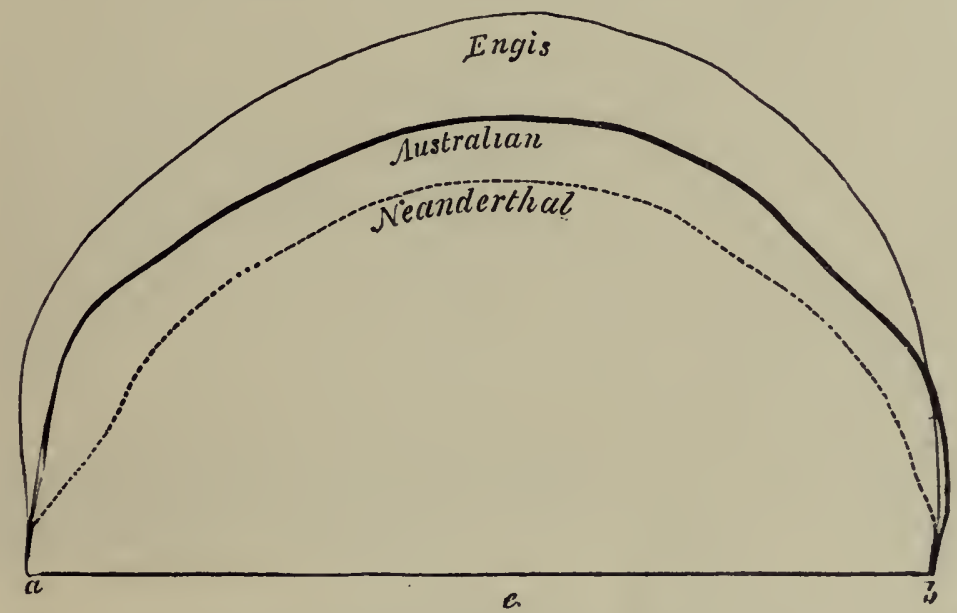

Profile View of Cranium of Primitive Types.

Lenormant, Histoire ancienne de l'orient, I, 138.

stance of primitive anthropology, still commands a special interest and will, in addition to the comments and pictures presented to our readers, justify the publication of some pertinent quotations which were collected by $\mathrm{Mr}$. Charles $\mathrm{H}$. Ward of Rochester.

Dr. Fuhlrott describes the locality where the remains were discovered in the early part of 1857 as follows :

"A small cave or grotto, high enough to admit a man, and about 5 feet deep from the entrance, which is 7 or 8 feet wide, exists in the southern wall of the gorge of the Neanderthal, as it is termed, at a distance of about Ioo feet from the Düssel, and about 
60 feet above the bottom of the valley. In its earlier and uninjured condition, this cavern opened upon a narrow plateau lying in front of it, and from which the rocky wall descended almost perpendicularly into the river. It could be reached, though with difficulty, from above. The uneven floor was covered to a thickness of 4 or 5 feet with a deposit of mud, sparingly intermixed with rounded fragments of chert. In the removing of this deposit the bones were discovered. The skull was first noticed placed nearest to the entrance of the cavern; and further in, the other bones, lying in the same horizontal plane. Of this I was assured in the most positive terms by two laborers who were employed to clear out the grotto, and who were questioned by me on the spot. At first no idea was entertained of the bones being human; and it was not till several weeks after their discovery that they were recognized as such by me, and placed in security. But, as the importance of the discovery was not at the time perceived, the laborers were very careless in the collecting, and secured chiefly only the larger bores; and to this circumstance it may be attributed that fragments merely of the probably perfect skeltton came into my possession."

Dr. Fuhlrott condenses his conclusions in these three statements :

"First: That the extraordinary form of the skull was due to a natural conformation hitherto not known to exist, even in the most barbarous races. Second: That these remarkable hum in remains belonged to a period antecedent to the time of the Celts and Germans, and were in all probability derived from one of the wild races of North western Europe, spoken of by Latin writers; and which were encountered as autochthones by the German immigrants. And thirdly; That it was beyond doubt that these human relics were traceable to a period at which the latest animals of the diluvium still existed; but that no proof in support of this assumption, nor consequently of their so-termed fossil condition, was afforded by the circumstances under which the bones were discovered."

\section{Darwin mentions the subject in The Descent of Man:}

"The belief that there exists in man some close relation between the size of the brain and the development of the intellectual faculties is supported by the comparison of the skulls of savage and civilized races, of ancient and modern peoples, and by the analogy of the whole vertebrate series. Dr. J. Bernard Davis has proved, by many careful measurements, that the mean internal 
capacity of the skull in Europeans is 92.3 cubic inches; in Americans 87.5 ; in Asiatics 87. I; and in Australians only 81.9 cubic inches. Professor Broca found that the nineteenth century skulls from graves in Paris were larger than those from vaults of the twelfth century, in the proportion of 1484 to 1426 ; and that the increased size, as ascertained by measurements, was exclusively in the frontal part of the skull-the seat of the intellectual faculties.

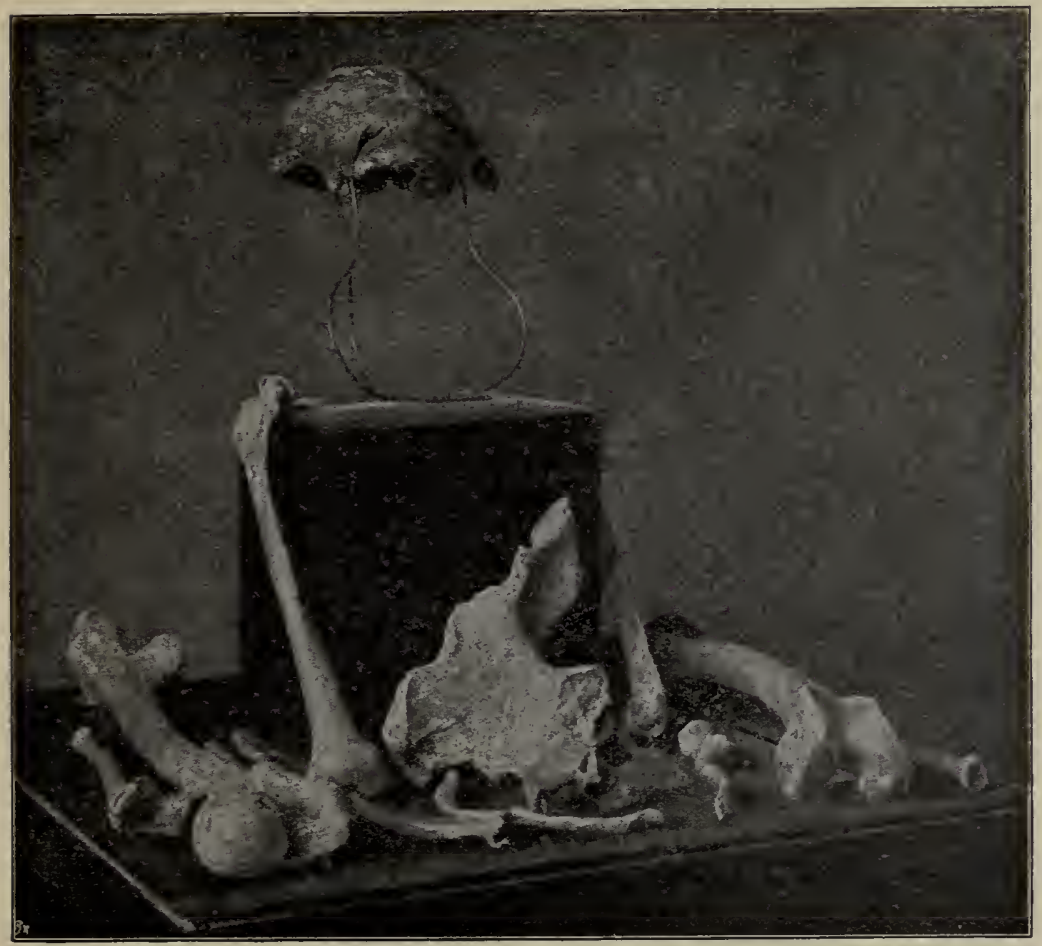

Fossil Relics of the Neanderthal Man in the Provincial Museum AT BonN.

(Weltall und Menschheit, II, 3 )

Prichard is persuaded that the present inhabitants of Britain have 'much more capacious brain-cases' than the ancient inhabitants. Nevertheless, it must be admitted, that some skulls of very high antiquity, such as the famous one of Neanderthal, are well developed and capacious."

Huxley in Man's Place in Nature says .

"Under whatever aspect we view this cranium, whether we 
regard its vertical depression, the enormous thickness of its superciliary ridges, its sloping occiput, or its long and straight squamosal suture, we meet with apelike characters, stamping it as the most pithecoid cf human crania yet discovered.... And indeed, though truly the most pithecoid of human skulls, the Neanderthal cranium is by no means so isolated as it appears to be at first, but forms, in reality, the extreme term of a series leading gradually from it to the highest and best developed of human crania."

Finally we quote the statement of a distinguished anthropologist still living, Prof. Paul Topinard, who in his Anthropology makes the following statement :

"Human palæontology commences with the Post-pliocene or Mammoth epcch. Examples of it are few in number, and not readily capable of classification. De Quatrefage and Hamy, however, have not flinched from this difficult task. By joining together
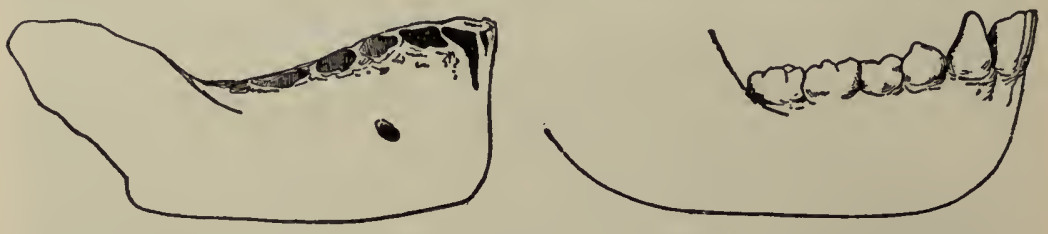

The Jawbone of Naulette compared with that of a Chimpanzee.

fragments of male skulls from Cannstatt, Eguisheim, Brux, Denise, and the Neanderthal, and female skulls from Stroengenœs, L'Olmo, and Clichy, they succeeded in discovering in them certain common characters; that is to say, dolichocephaly, a remarkable sinking of the vault of the skull, or platycephaly, a great recession of the frontal bone, and a very marked development of the superciliary arches. Of all the specimens, the most remarkable are the calvarium of the Neanderthal and the jaw of La Naulette. Any one accustomed to handle the skulls of the anthropoid apes will be immediately struck with the great resemblance between them. The Neanderthal especially reminds one of the calvarium of the female gorilla, which is similarly staved in, as it were, or of the skull of a hylobate. The superciliary arches are altogether simian, although the skull is clearly human. Its capacity, estimated at 1200 cubic centimetres, dissipates all doubt on the subject." 


\section{DU BOIS'S PITHECANTHROPOID.}

WHILE digging for fossils on the island of Java, Professor Du Bois discovered some bones in the

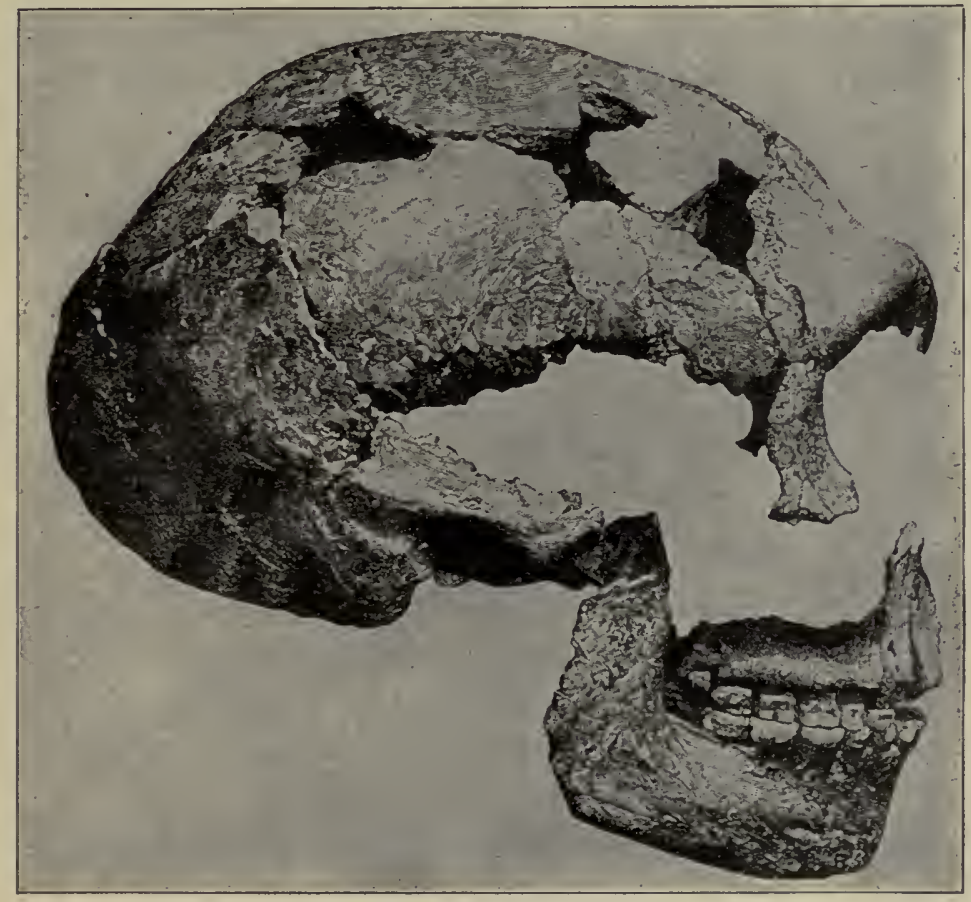

Skull of Prehistoric Man of Spy in Belgium.

From Professor Fraipont's photograph of the original in the Museum at Liège. (Weltall und Menschheit, II, 21.)

year 1891 on the banks of the Bengawan river near the Trinil farm. The sand is volcanic and so the theory sug- 
gests itself that the creature to whom these interesting relics belong became the victim of a volcanic eruption, yet he was saved to posterity in the same way as the cities of Pompeii and Herculaneum. When the rain water carried away the volcanic dust it scattered and took with it some of the bones. We might further mention that they are all in a petrified condition and nothing of the originally organic substance is left. There in the midst of tertiary

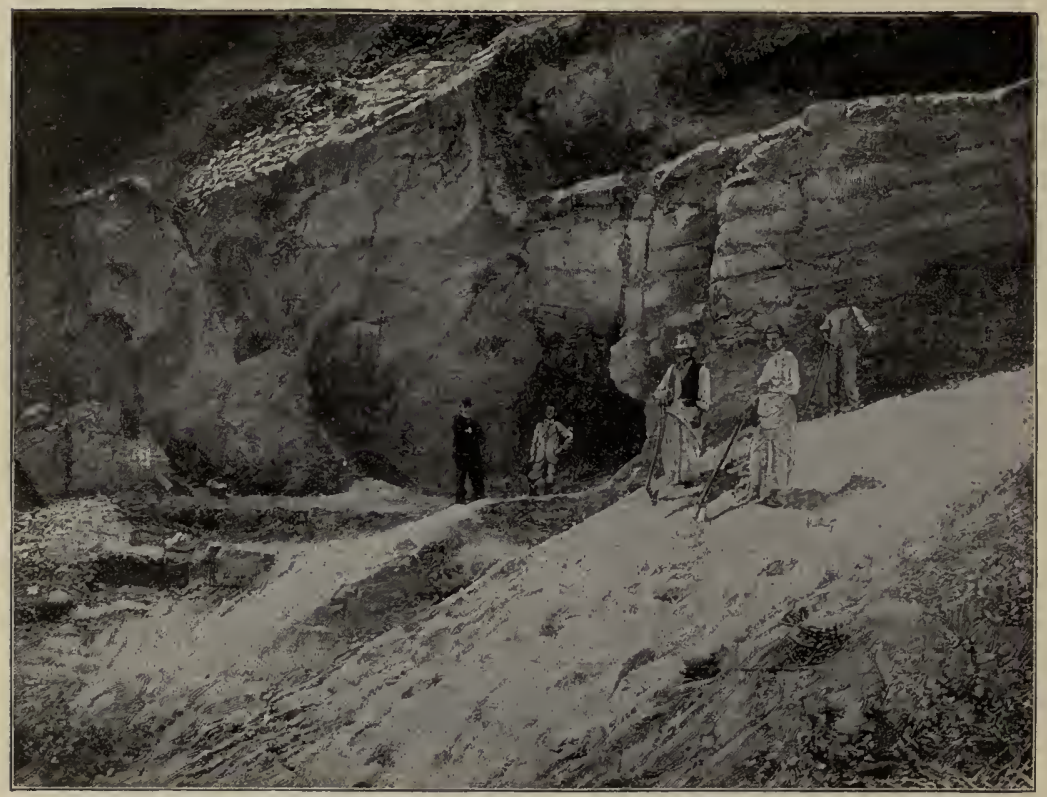

The Krapina Cave in Croatia.

drift Professor Du Bois came quite unexpectedly upon a cranium which in form is midway between the human and Simian skulls. At a distance of about twenty-five metres he found a human femur which in addition to its unusual straightness shows a diseased growth, the latter being an evidence of an injury received during lifetime and partly healed. There was also nearby a molar tooth nnequivo- 
cally human but unusually broad with widely diverging roots.

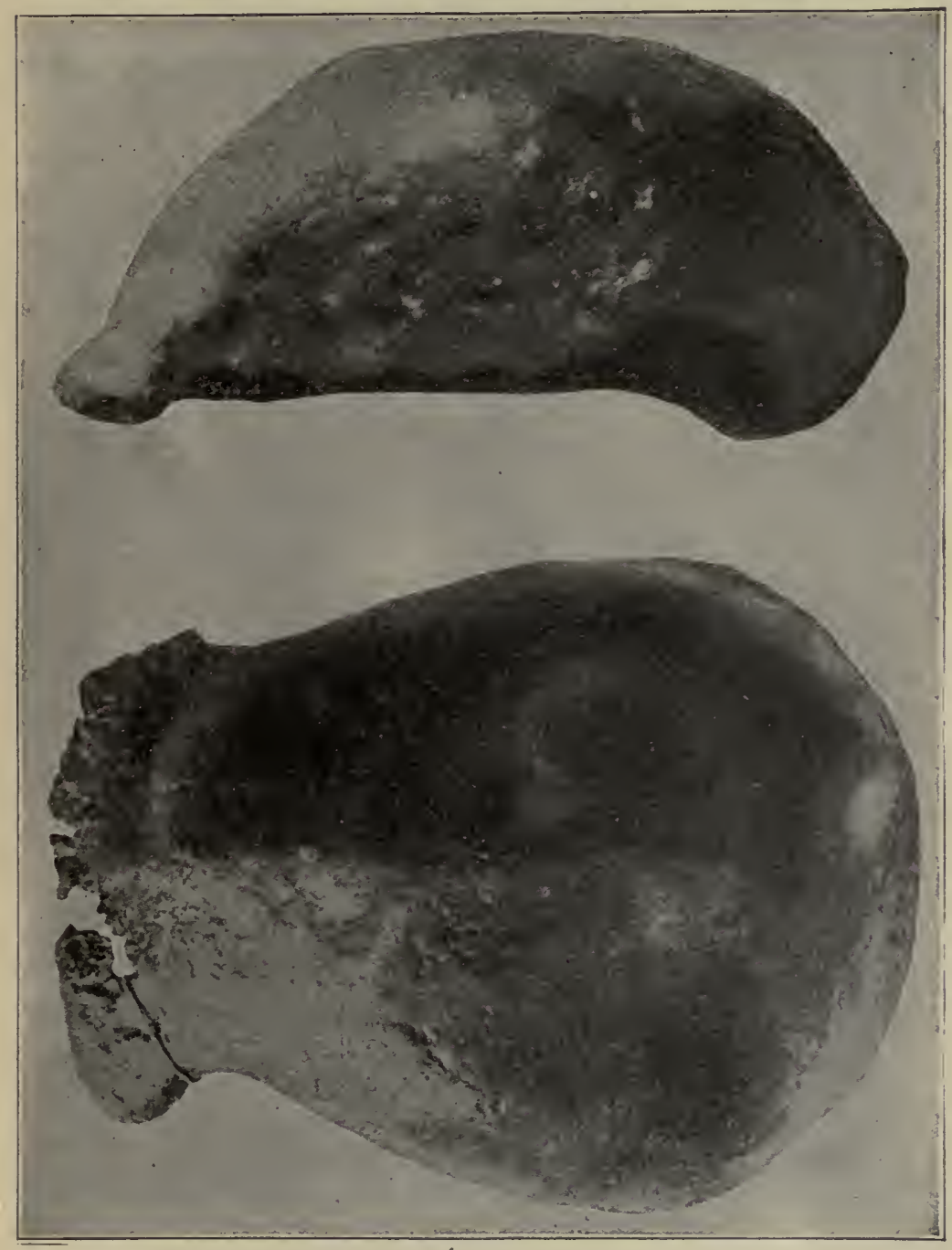

Cranium of the Pithecanthropus Erectus Du Bois.

Seen from side and top. (Weltall und Menschheit, II, J77.)

The straightness of the femur induced Professor Du Bois to call his foundling by the qualifying appellation 
erectus, but Hermann Klaatsch and his colleagues have pointed out that the typically human bone is exactly distinguished by a slight curve, and so it appears that the straightness of the bone has nothing to do with man's erect carriage. Hence it is not impossible that Du Bois's pithecus anthropus erectus may have been nearer in his walk to the Simians than his discoverer assumes.

The broadness of the tooth and the expanded character of its roots indicate that the jawbone must have possessed sufficient space for molar teeth, and thus favor the assumption that the mouth of its mainly herbivorous owner was more Simian than human.

While the breadth and length of the Javan ape-man's skull are not inconsiderable, its height is extraordinarily low, and the processes at its rear for the attachment of the muscles of the back plainly prove that the owner of this interesting relic possessed a very short stout neck not unlike that of the anthropoid apes.

In addition to these characteristic traits the skull of Du Bois's man exhibits the same orbital ridges as the skull of the Neanderthal man, a feature also noticed in the fossils of the Spy and Krapina caves. All other skulls of primitive men that have so far ever been discovered, especially the skulls of the Cro-Magnon cave in the valley of Vezère (France), are of a higher type and represent a nearer approach to the human, both by an absence of the orbital ridges and by a considerably increased height and braincapacity.

There are enough traces of the ape-man to establish his whilom existence beyond a shadow of doubt, but theer are not enough facts to give us any further information about details. No one knows how many centuries or millenniums it took to develop the species pithecanthropus into primitive man, and why the former became extinct with the appearance of the latter is a subject of surmise, not of positive knowledge. 


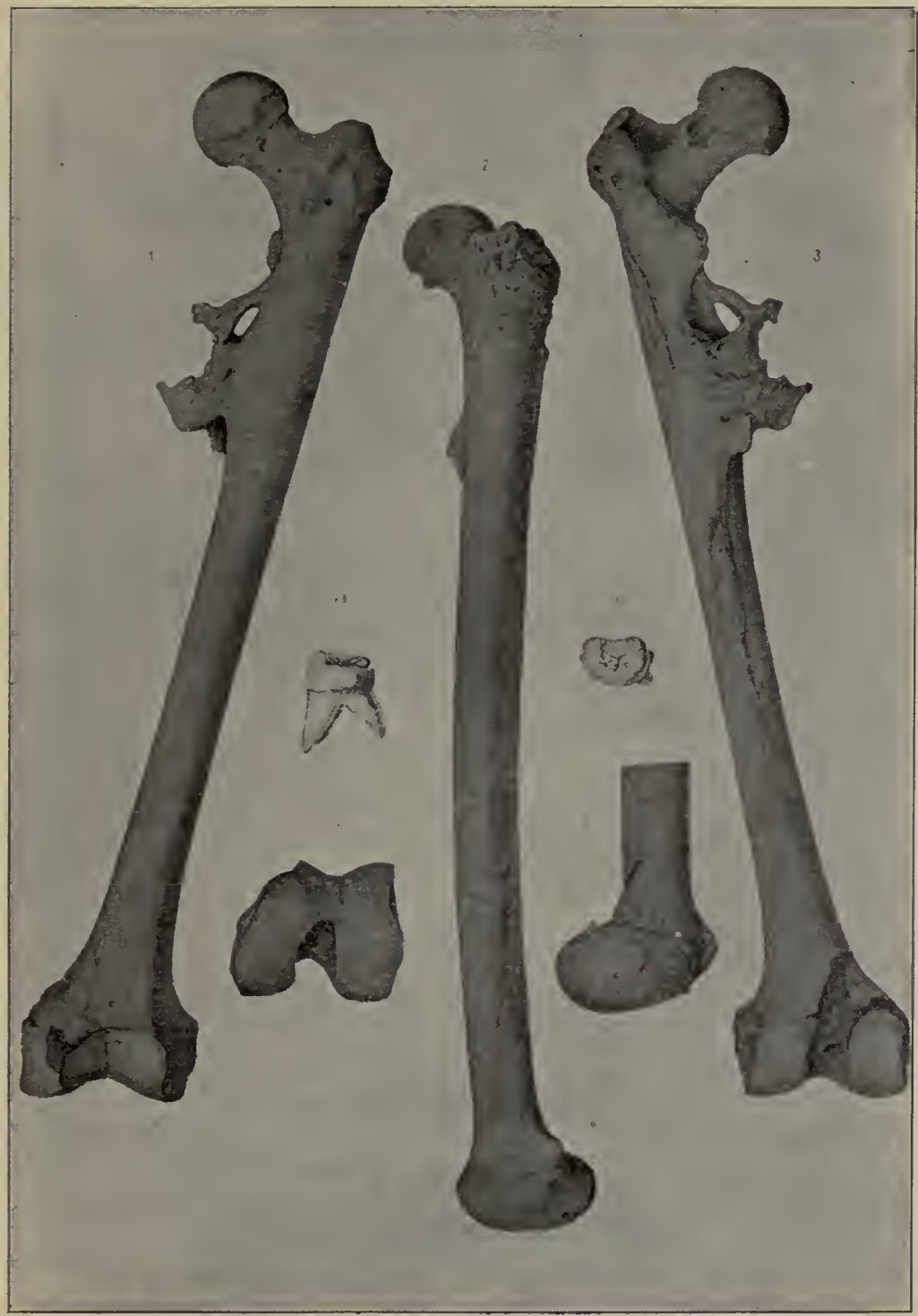

Relics of the Pithecanthropus Erectus.

Left femur: (r) front view, (2) outside view, (3) back view, (4) from below, (5) inside view of lower end. Third upper right back tooth, (6) showing surface of masticatinn (6a) back view. 
OUR FRONTISPIECE.

The artist Gabriel Max has dared to reconstruct an image of the ape-man, and having devoted many years of study to the shape of the anthropoid Simians as well as to

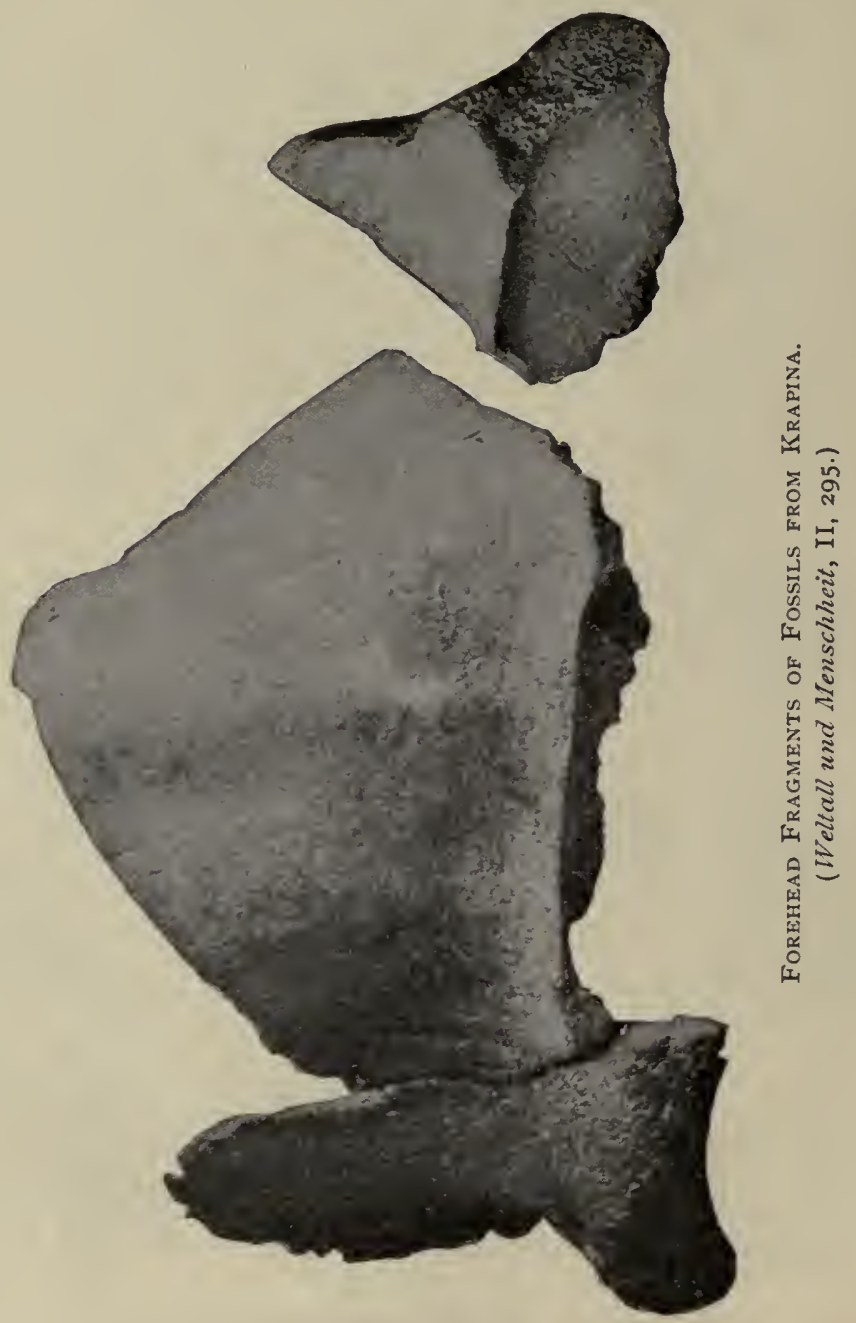

the doctrine of evolution, he has thrown his ideas on canvas and dedicated his picture to his friend Prof. Ernst Haeckel of Jena. 
The picture is at first sight repulsive. There we have portrayed a family of the ape-man, kin to the species found in Neanderthal, Cannstatt, and Spy, who must have been more savage than the savages. His brutish nature

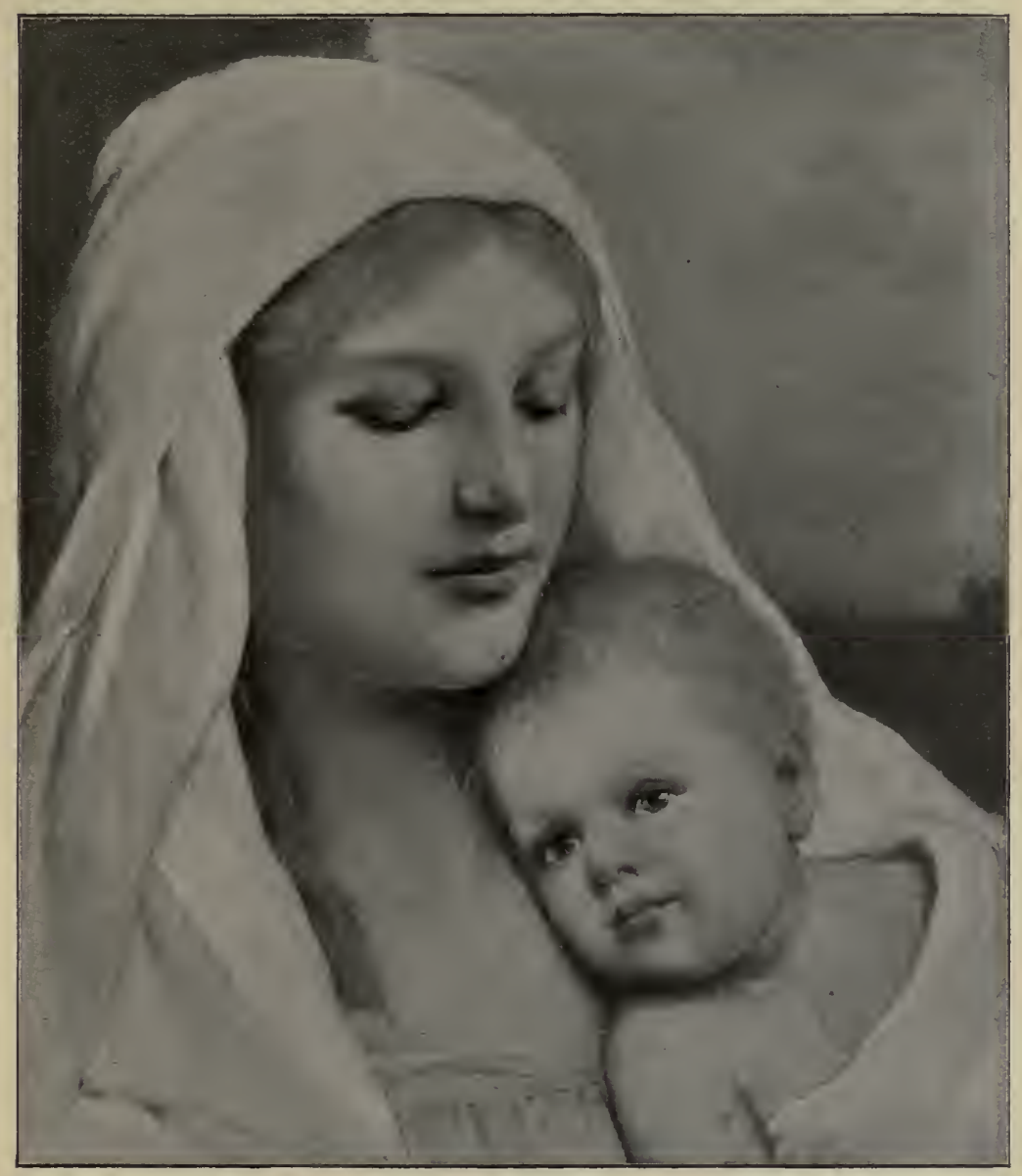

Madonna and Child. (By Gabriel Max.)

still shows in his bodily appearance and yet the more we look at the picture the more it gains on us !

Verily, we discover a close resemblance of the scene represented by Gabriel Max to pictures of the holy family. And considered rightly, the similarity is by no means 
fortuitous, for here we have indeed a holy family. It is an uncultured primitive couple of a speechless tribe of forest men, yet the hope of progress and a brave determination to take up the battle of life for the sake of the babe that is born to them becomes visible in the mother's eyes.

Gabriel Max was equal to the great task of showing man at the beginning of his career in a low state, and he understood how to make us comprehend that we behold here, not the downfall to a state of degradation, but the rise to a higher and nobler development of life. We can plainly see that these creatures, half animal, half man, contain in their aspirations the grand possibilities of humanity. The picture is of extraordinary exactness if judged from the standpoint of anthropology, but even if it were not, the main idea of the artist comes out clearly and is vividly pictured before us-a brute rising into manhood! This much is certain, that the artist has understood how to portray the ancestors of man not as mere brutes, but as aspirants for a higher life, at a moment when their souls were blossoming out into that fuller mentality, which, with its intellectual depth and moral breadth, we call human.

Gabriel Max was prepared for his task in a twofold manner ; first by his study of the physiology and anatomy of the ape and his knowledge of the doctrine of evolution, and secondly by his previous work in the line of Madonna paintings. The influence of the latter is so strong that the weak point noticeable in all the Christian representations of the holy family (the depression of the ideal father into a mere foster-father) is still apparent here. The father of the babe looks too much like St. Joseph, like an old reliable servant and an uninterested guardian, not like a husband and parent, who takes a personal interest in his wife and child and would burn with rage at any danger that might disturb the peace of his little family circle. 


\section{CIVILIZATION AND THE RACE.}

$W^{\mathrm{E}}$ have no intention of entering into the intricate problem of the mode of progress, and will not venture to decide the mooted question of Weismann whether or not acquired characteristics are inherited; consequently whether evolution is due to a selection of certain germs fit for survival, or to the use and disuse of several organs which will either strengthen or weaken certain qualities. All rival theories on this subject agree as to the main facts. They all accept the doctrine of evolution and vary only as to the explanation attributing to nature different modes of operation. The Lamarckian school explains evolution mainly by use and disuse of organs. Function is first. Function produces modifications in the structure of living organisms, and these modifications become organic so as to be inherited. The proposition of the inheritance of acquired characteristics, however, has been challenged by Weismann, who claims that no unequivocal instance that could serve as a proof has yet been produced, for all experiments of artificial mutilation have failed and thus favor the opposite theory that the type of the race is permanent. Moreover, evolution of new species takes place in instances, such as ants and bees where a heredity of acquired characters is absolutely excluded. Neither the queen nor the drone takes part in the labors of the hive and yet we can observe the origin of new species, in which the characteristics of the worker-bee and the worker-ant are modified. Ant communities as well as bee hives are like living organisms, 
in which the single organs are split up into innumerable individuals and there can be no question that the womb (i. e. the queen) of the collective creature lives physiologically in absolute separation from the rest and no direct transmission of acquired characteristics of the workers is possible. According to Weismann, therefore, the process of evolution is due to a selection of germs containing characteristics better adapted to conditions, and the rise of a difference in these germs is not due to any use and disuse of organs, or whatever the workers may do or leave undone.

Weismann's critics pointed out that in human society the children of scholars would show a greater refinement than the children of their brothers who had lived as farmers, that the latter showed more bony structures than the former, and so indicated that use and disuse affected the system, and that these characteristics became hereditary; but Weismann explains such instances by a predisposition contained already in the germ. He would say that the predisposition to become a scholar or a farmer was already contained in the germs, and had determined the occupation of the several numbers of one and the same family, and though this would seem strange at first sight, it can not be disproved.

It is a well known fact that the little toe of man is undergoing at present a constant degeneration, commonly attributed to the use of shoes, but Weismann proves that this degeneration can not be due to the pressure of shoes because it takes place in perfect independence of the use of foot-wear. The degeneration of the little toe is traceable also among savages who never in their lives had a shoe on their foot, and also in the bodies of the most ancient mummies, who lived before the invention of our modern boots. The reason of this degeneration accordingly is not the actual use and disuse of the little toe, but because the use of the toe is not needed, and so the individ- 
uals with an imperfect toe had for millenniums the same chance of survival as those in whom it was as fully developed as other toes. If such conditions in which the imperfect form of a limb has no special disadvantage continue for any length of time imperfections are naturally favored, or at least on equal terms with normal forms, and so the crippled limb will through panmixia gradually displace the original form.

If Weismann's view is correct the race can be modified only by a modification of the germ. While this would slacken the pace of evolution, it would at the same time act as a check on sudden changes and thus make the advance wherever it occurs more assured. It would base the mutation not on haphazard incidents or particular conditions of individuals, but would have them rooted in the more recondite region of the germ, where they would be more stable and less easily displaced. The evolution of the race would be accomplished by a selection, not of individual characteristics, but of racial traits, which would prevent rapid obliterations of well established characteristics, and put the appearance of new modifications to a severe test.

Changes are brought about by two forces that counteract one another; one is expansion, the other elimination. When conditions are favorable life sprouts forth and produces great varieties of new forms, some of which possess desirable qualities, while others indicate a weakening of the type and aberrations. Good times produce superior types together with many others that are inferior, but when the time of tribulation arises the weaker forms quickly die off and leave only the stronger ones. Good times give a chance to any form of life, while hard times put creatures to the test and select the fittest for survival. In good times the weak and the strong, the clever and the stupid, the poorly endowed and the well equipped, have frequently equal chances to make an easy living, and 
there is a tendency that makes both the tares and the wheat grow together in liberal exuberance. If nature had not hard times in store for her creatures, evolution would lack definiteness and would scatter in many directions; for in that case freakish and degenerated formations would not be excluded but grow in unlimited possibilities. We owe it to hard times that the evolution of life favors a definite type which leads higher and produces better and stronger creatures, thereby pruning the exuberance of wild tendencies and cutting off the aberrations from the straight and narrow path of progress.

Professor Lloyd Morgan in his book on Animal Life and Intelligence (p. $114 \mathrm{ff}$.) explains the effect of an alternation of good and hard times thus :

"During good times varieties, which would be otherwise unable to hold their own, might arise and have time to establish themselves. In an expanding area migration would take place, local segregation in the colonial areas would be rendered possible, differential elimination in the different migration-areas would produce divergence. There would be diminished elimination of neutral variations, thus affording opportunities for experimental combinations. In general, good times would favour variation and divergence.

"During the exhibitions at South Kensington there were good times for rats. But when the show was over, there followed times that were cruelly hard. The keenest competition for the scanty food arose, and the poor animals were forced to prey upon each other. 'Their cravings for food,' we read in Nature, 'culminated in a fierce onslaught on one another, which was evidenced by the piteous cries of those being devoured. The method of seizing their victims was to suddenly make a raid upon one weaker or smaller than themselves, and, after overpowering it by numbers, to tear it in pieces.' Elimination by competition, passing in this way into elimination 
by battle, would, during hard times, be increased. None but the best organized and best adapted could hope to escape."

The law is not limited to animal life but holds good also with man. Professor Morgan says :

"The alternation of good times and hard times may be illustrated by an example taken from human life. The introduction of ostrich-farming in South Africa brought good times to farmers. Whereupon there followed divergence in two directions. Some devoted increased profits to improvements upon their farms, to irrigation works which could not before be afforded, and so forth. For others increased income meant increased expenditure and an easier, if not more luxurious, mode of life. Then came hard times. Others, in Africa and elsewhere, learnt the secret of ostrich-farming. Competition brought down profits, and elimination set in-of which variety need hardly be stated."

These observations convey a moral lesson which will make us appreciate the significance of misfortunes which all creatures have to encounter at times, in the development of life. We would not have reached our present state of civilization had the human race not previously met with enormous hardships and times of trial.

And the end is not yet, for there is more in store for us, although it is not probable that there will be again such universal and thorough eradication of whole tribes and communities, for civilization holds misfortune in check and acts as a saving power of extraordinary efficiency ; yet in the measure that it does so it retards the development of the racial type.

Civilization is a new factor in the world and it is difficult to prophesy what it will accomplish. No one doubts that it is here, nor can we question its beneficial effects which appear most obviously in the mutual assistance that man offers to man in social and charitable institutions, 
thus mitigating the fierceness of the struggle for existence and keeping alive those things which otherwise would have died.

The spirit of civilization is reflected mainly in the ethical tendencies of the religions which characterize this period, foremost among them being Buddhism and Christianity. The trend of it might be expressed in the word of Jesus who in his turn quotes from the Hebrew forerunners and path-finders of the age of the Son of Man that " a bruised reed shall he not break, and smoking flax shall he not quench."

Civilization is practically the religion of the present age, for whatever faith different people or nations may confess, all religious leaders of the living present endeavor to bring it abreast with the moral principles of civilization. In fact if they try to prove their religion to be true, they are mostly satisfied with pointing out that it supports and agrees with our ideal of civilization.

But while we can not sufficiently praise the boons of civilization, we must at the same time recognize that like all things of this world, civilization has its weak points. It would be a mistake to think that civilization per se pro. duces a higher type of man. It renders life comfortable but does not make the type progressive. Progress in all lines is the result of necessity and the man of yesterday could not have produced the civilization of to-day without having previously been prepared for it by a selection of the fittest, who were chosen to do the work ; as Dr. Charles E. Woodruff puts it, "Brain makes civilization, and civilization never makes brains." $\%$

The period of anthropogenesis, i. e., the age in which

* American Journal of Insanity. No, I, p. Io, July, rgor.

After the first publication of my articles on the rise of man (in The Open Court, March I904 and Jan., Feb. I906) Dr. Woodruff courteously sent me his essay entitled "An Anthropological Study of the Small Brain of Civilized Man and its Evolution," which contains a number of pointed conclusions; and passing over such arguments as would in my opinion need modification I will make extensive quotations and reproduce two of his diagrams. 


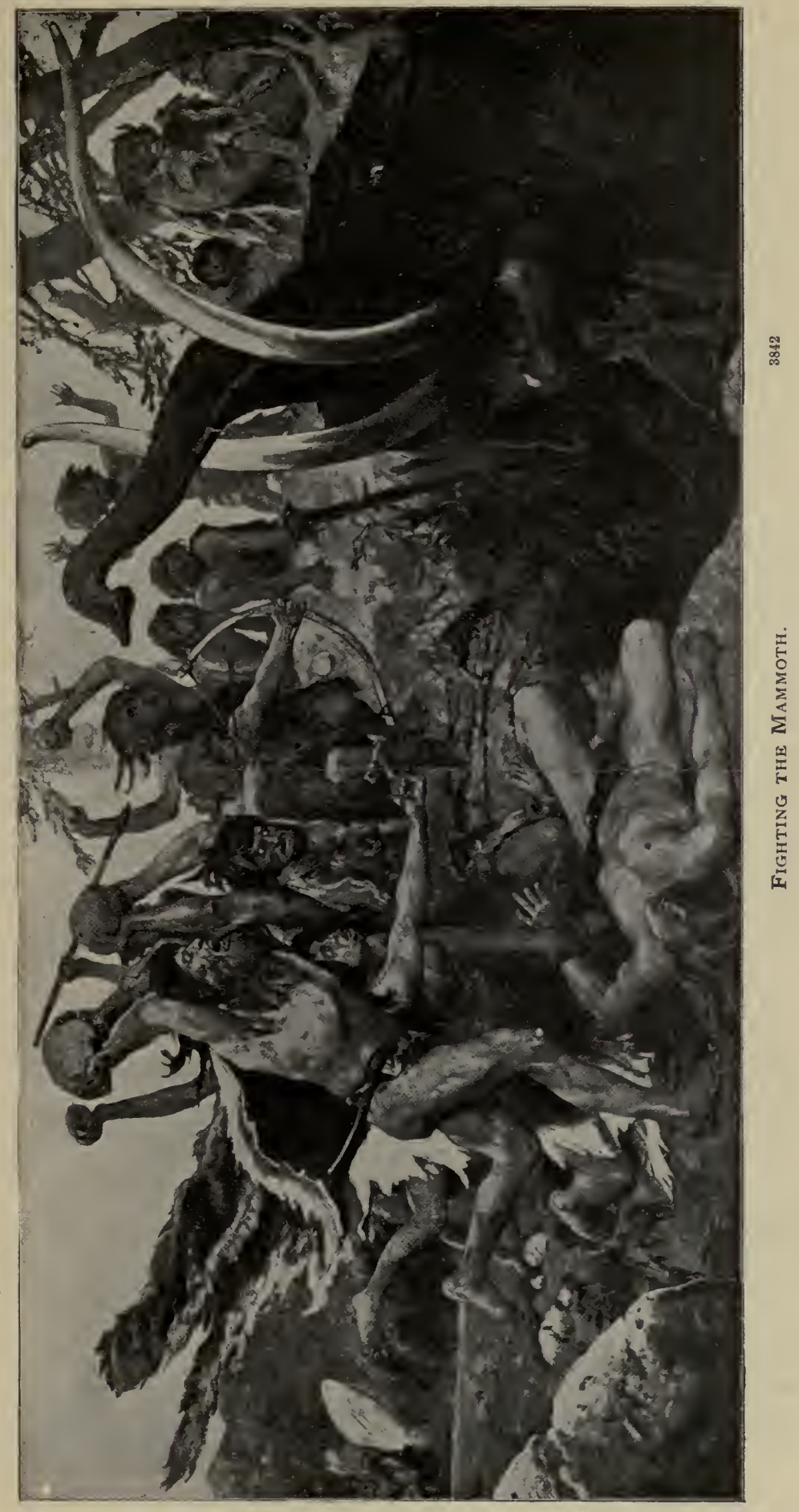


the human race originated, was a continued era of hard times. There was no other shelter than the caves accidentally formed by nature. Food was scarce and difficult to procure, while the struggle with wild animals, especially the mammoth and the bear, must have taxed the energy of a primitive community to the utmost.

Civilization may be characterized as man's mastery of hard times; its aim is to continue good times, and so it preserves the unfit and allows their qualities, by what Weismann has called panmixia, to continue as typical features of the race. In this way the brain capacity of man shows a very insignificant advance since the time of savagery, for the higher a civilization and the prosperity of a community ranges, the easier it will be for lower types of mankind to survive.

Dr. Woodruff says :

"In whatever direction we seek, we are sure to find remarkably clear evidence that man's brain developed to its maximum size long before the dawn of civilization by the process of natural selection in an environment which eliminated the least intelligent in each generation, and that civilization always checks the process.

"Our pre-glacial ancestor, in that tropical climate which extended nearly to the pole, may have had so little trouble in getting food that it was the active and agile intelligent ones best fitted to escape the enemies of the times, who were the best adjusted to the environment and who survived in greater numbers. Now what a change occurred in the very slow and gradual approach of the long cold! What a struggle began with a wiping out of species which could not find fit variations adjusted to the change, and what a mortality there must have been among our most stupid ancestors, and therefore what a rapid evolution of brain when the most intelligent survived, and no others, in each generation.

"Like the protozoon, man was at first a jack-of-all- 
trades, and a skillful one too. Instead of being gregarious he was probably a free lance like an amoeba, possibly living in pairs either temporarily like the birds or a more or less permanent union. After a long time those who were grouped into communities survived because they could live better than in independence. By union a community was better fitted for existence just as the protozoon colonies. A long time after living in a clan, man was almost as independent as when he was a free lance. He practiced all his functions just as before and the colony was nothing more than a group of individuals living independently but near together. It was precisely like the first multicellular organisms which were composed of identical cells each of which did exactly like all its neighbors. There was no division of labor.

"This was probably the period of man's greatest average brain development. Long after his organization into tribes and even nations, at or even after the dawn of civilization, each man could do every thing well. He could hunt, fish, build houses, make arms, chip flints, be a soldier and fight, protect his home, tan hides, make clothes of skins and sandals of leather, look after a wife or so, and he knew much about the weather, woodcraft, zoology and botany too. Indeed he could do all these things before he had learned to talk except by a few cries and grunts. Dr. G. A. Reed (Present Evolution of Man) says he has seen Maoris of New Zealand equal in power of mind to average Europeans.

"We should think for a moment what a large amount of brain it requires to do all this successfully. The skill and intelligence needed in woodcraft alone would tax the mental powers of the average modern man. Then we must think of the result of not having enough intelligence to do all this, - inevitable death-for in those conditions men were too busy keeping themselves alive to have any spare time to preserve the weaklings. 
"During this time and for a very long time previous, survival of the fittest was the same thing as survival of the brainiest. It is certain that when by climatic changes, man's environment became unfriendly, he had to think, scheme and contrive or die. There must have been a rapid evolution of brain if we are to judge from embryological evidence and of course a great mortality among the less intelligent. It is possible that a single thought may have been sufficient to save one man out of many, for if he had happened to think that he ought to hide some food, he may have had enough to tide him over a period of winter starvation which carried off most of the tribe. We know that just such period of stress, carrying off the less provident, actually occurred among our Pacific Coast Indians as late as the end of the first half of the present century."

Civilization alleviates the lot of man. The beginning of this tendency becomes apparent even in the age of the caveman and it is on the increase, the whole of society being made more and more responsible for the comfort of all its members. With a gradual spread of civilization, the unfit are no longer eliminated. Says Dr. Woodruff :

"A man possessed of a single useful faculty may succeed in civilized life, though his general intelligence may be so limited that he would have perished in a savage life. $\mathrm{He}$ is adjusted to a civilized environment and fit for survival, but in a savage environment he would be so out of adjustment as to perish in the struggle for existence.

"Psychologists have frequently called attention to the fact that in civilized life among laborers there are many imbeciles whose defects are hidden because they are never called upon to do anything requiring intelligence. All of these men are fitted for survival now, whereas in prehistoric times they would have perished before maturity if not killed by their parents.

"Every degree of intelligence can find a sphere of 


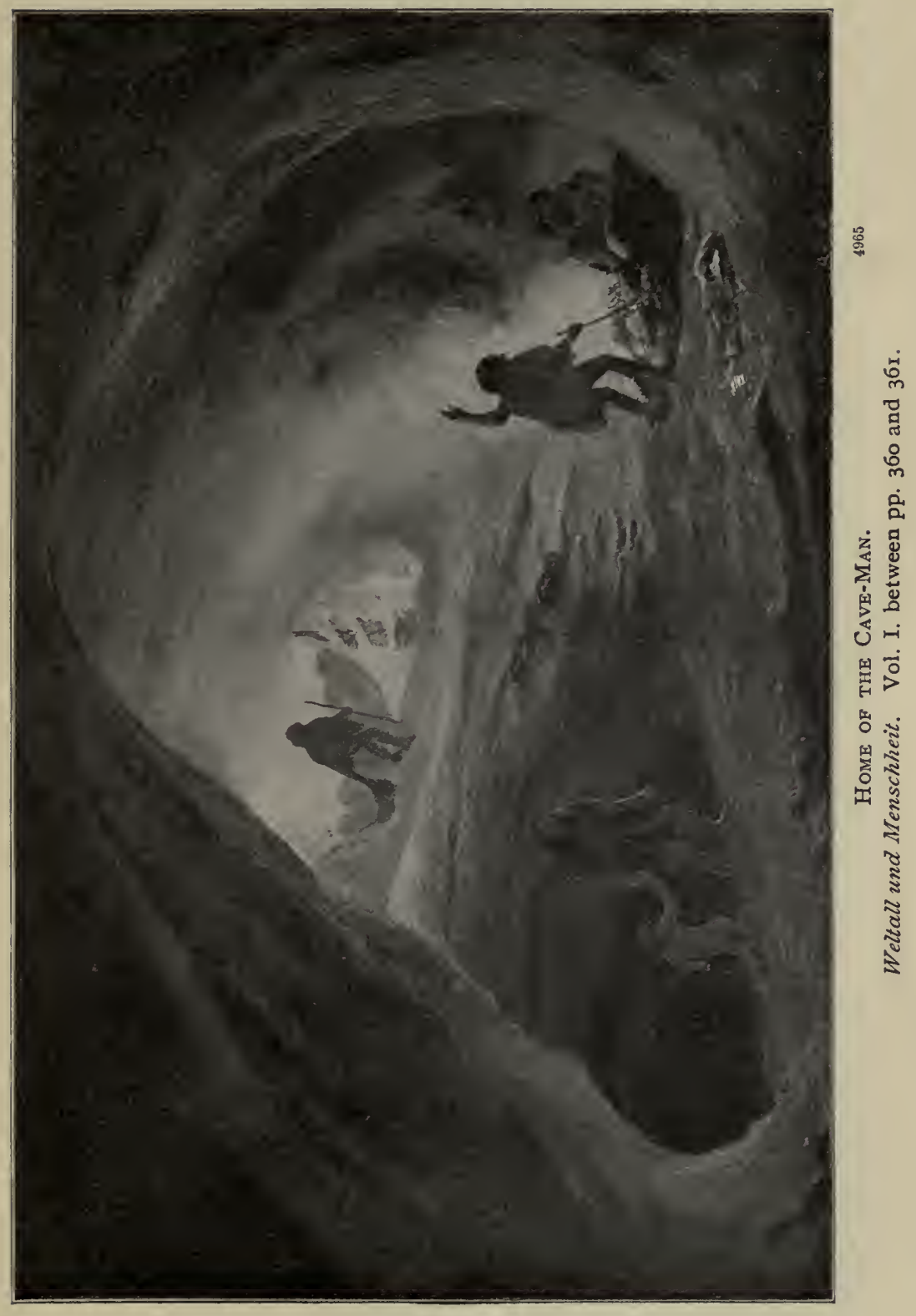


activity in which to struggle successfully for existence as a specialized unit in organized society. They are all fitted for survival and they all leave offspring."

The origin of civilization is due to favorable conditions in which man can make use of his superiority acquired during hard times.

The oldest fossils of anthropoid apes are found in the eocene and miocene strata, and we must assume therefore that the genesis of man started in the pliocene period. The pliocene period then is the age of the man-ape who left no records, for the implements he used for many millenniums were the stones he picked up and the bones of the hunted animals he had gnawed. Accordingly we can not expect to find unequivocal evidences of his activity or intelligence. When he first began to chip flints he ceased to be a man-ape and became an ape-man or pithecanthropus, a fair promise of the true man.

Almost simultaneously with the appearance of the ape-man is the beginning of the ice age which reached its climax in the pleistocene period and must have been very hard on this new species in the animal creation. It was a severe school, but to its very severity man owes his most precious qualities, foresight, earnestness of purpose, responsibility and conscience, based upon a feeling of solidarity with other members of the same community

We assume that this ape-man or pithecanthropus had been temporarily cut off from a retreat to warmer regions and so he was compelled to work out the progress of the race under penalty of extinction. We assume further that from time to time some families or tribes escaped to the south and found there more comfortable surroundings, but as soon as their hardships ceased, their development was arrested, and so their several types constitute the milestones on the path of progress, mementoes of what the man of today might be had he not longer remained in the school of anthropogenesis. There are the Veddas of 
Ceylon, the Nigritoes of the South Sea Islands, the Bushmen, the Hottentots, the Negroes of darkest Africa, and of the Soudan. In the meantime the advance of the race continued in the north.

We must regard the Neanderthal man as a typical specimen of the ape-man, while the skeletons of Spy indicate already an advance. One skull of Spy possesses very little more brain capacity than the Neanderthal man, while the other indicates a considerable increase, as can be seen in the diagram of Fraipont and Lohest.

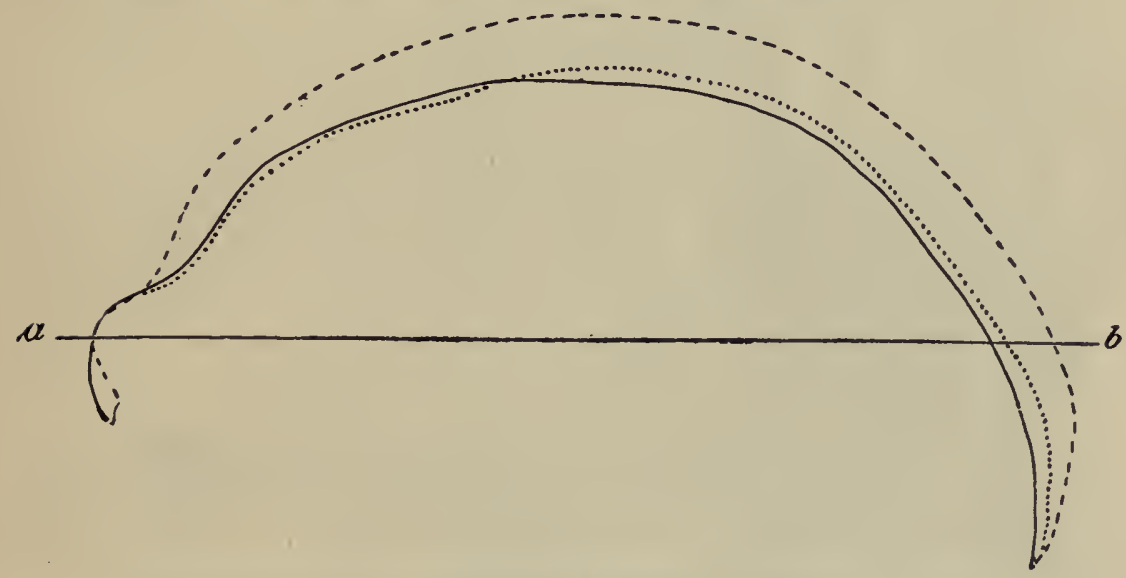

Outlines of the Skulds of the Neanderthal Man and of the two SKELETONS OF SPY. 3479

From Fraipont and Lohest.

The dotted lines represent the calvaria of the Spy skulls.

Further progress is rapid. We find the Cro-Magnon type succeeded by the Mediterranean race, and different types bred in different parts under different conditions produced long heads and broad heads whose intermixture again constituted a favorable factor in the production of the most intelligent specimens of mankind, who at last were sufficiently well equipped in brain capacity to be fit material for the production of civilized man.

Man's growth of brain power during the ice age was rapid if compared to previous periods in the history of 
creation although it was slow enough if measured by the rapid changes of the present time, and this is one main reason why there are so few traces of man's activity in the incipient stage of his manhood. All further steps of anthropogenesis through the stone ages, the paleolithic, the mesolithic, and the neolithic, can be traced at least in large outlines, and in the bronze age the dawn of history already begins to shed a clearer light upon the further advance of mankind toward civilization.

In the neolithic period the pace of civilization enters into a new period of unprecedented progress. Of the abrupt changes at the beginning of this period Dr. Woodruff says :

"An apparently sudden appearance of neolithic culture also depends upon the fact that civilization increases in a geometrical rate, because each new invention adds something to all previous ones, or acts as a multiplier, not a mere addition. Great inventions also are often a mere assembling of many previous minor ones. The steam engine for instance was built up of thousands of inventions, dating back even to the discovery of metals, and it is but one factor in all subsequent advance. It is also a matter of comment that great revolutionizing inventions are really very simple affairs. The advance in culture is so tremendously rapid now, not because the multiplier is any greater than with the mesolithic savage but because the multiplicand is tremendous. It is quite likely that a colony of modern farmers suddenly made ignorant of metals and transported to our iron fields, would take just as long, if not longer, to discover metals on their farms than did neolithic man, for they invent and discover just as slowly as ever. Marsh's estimate of 12,000 years for a savage to civilize himself must be entirely too short. It must have taken 160,000 years for paleolithic inventions to accumulate sufficiently to amount to a mesolithic stage, 


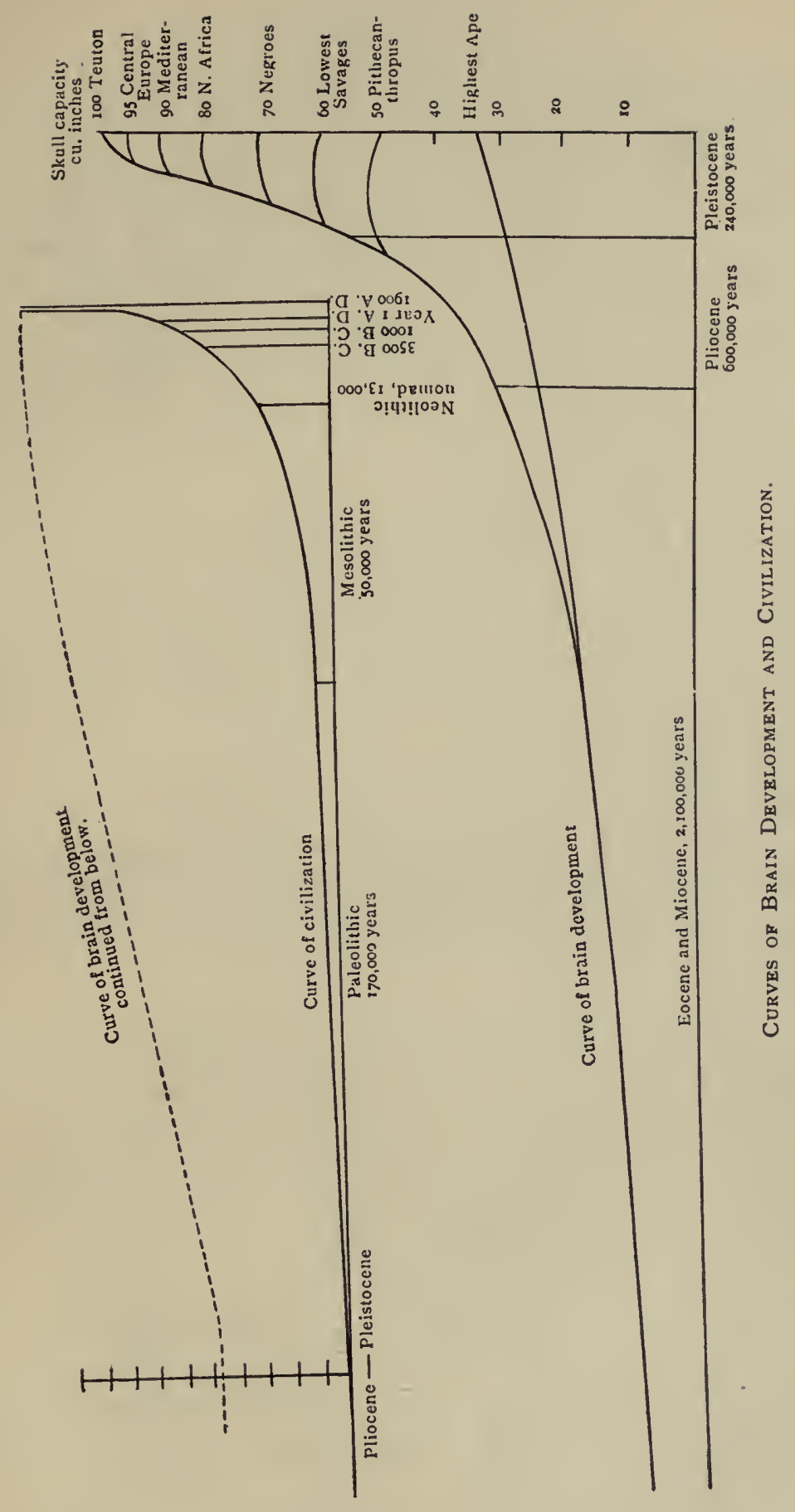


remembering of course that in the early part of that time he had less brain to work with than the lowest living races.

"It was not until 60,000 years more had passed that the sum of mesolithic inventions reached a neolithic age and the more rapid increase towards the end of course made it appear like a sudden jump in culture. In no other way than by assuming a geometrical increase of culture can we explain that remarkable jump to the neolithic. The mesolithic had but rude tools and pottery, no grain and the only domestic animal was the dog. The new age had pottery, artifical caves for houses, then lake dwellings, and such a sudden appearance of cows, pigs and goats that they were once thought to have been brought into Europe from the east, though a much later invasion really did occur. Yet we know from recent experiments that new varieties of domestic animals can arise in a much shorter time by artificial selection than we once thought - the estimates of biologists are undergoing constant reduction. So that the domestication of the above animals, though perhaps started by the mesolithic man, may have been accomplished by the neolithic in a short time, for we know that these bones were fairly numerous in the late neolithic.

"The pig and the horse were unknown to the early Egyptians and also to the Akkadians before the Semitic invasion. The wonderful resemblance between many breeds of domestic animals for a long time after birth so that experts may be deceived as to the breed until near maturity, is strong evidence of the very late specialization of these varieties by artificial selection.

"These suddenly appearing domestic animals are almost exclusively gregarious, and had undergone a natural selection for millions of years, fitting them for a semidependent existence in herds, and the transference of that dependence to man was an easy matter and need not have taken long." 
It is obvious, then, that evolution during the period of anthropogenesis consisted in an advance of the type of man, while at present the type is more stationary during the advance of civilization which moves forward with an increasingly rapid acceleration.

While it may be granted that civilization no longer eliminates the unfit in wholesale exterminations, it can not be said to mean a discontinuance of the further advance of the race, but the modus operandi is less drastic and therefore perhaps slower. While the unfit are preserved (or rather, while the elimination of the unfit has been considerably reduced) those individuals who represent a superior type are rendered conspicious by the acquisition of power, money, distinction, or fame. There are certain aristocracies forming, commercial, political, industrial, scientific, artistic, social and otherwise, and prominence within the several spheres of human activity, is partly a positive advantage, a means of survival, partly a stimulus to progress. Thus the process of evolution is not stopped but only modified, and though the fierceness of the struggle is abating the pace of advance is by no means checked. The main difference between the present and the age of anthropogenesis is mainly this, that primitive man struggled for survival, - for bare existence, while now the premium of the victor is success in life, prominence, wealth, or fame. 


\section{THE TRIUMPH OF THE BEST.}

THE concluding chapter of The Rise of Man shall be 1 devoted to the explanation of an important truth which is frequently misunderstood, viz., that man rose from a brute condition by virtue of superior qualities, not by brutishness and viciousness. Professor Huxley, strange to say, insists on the immorality of nature, and he is inclined to attribute the rise of man to his tiger-like fierceness and fox-like cunning, which, it is claimed, he learned in the stern school of life. But there is a flaw in Professor Huxley's reasoning, and while we are fully aware of the fierceness of the struggle for existence we cannot account for the gradual rise of mankind, except by the fact that primitive man cultivated in his family life social faculties and other noble instincts which improved his animal nature and made him what he is today.

Professor Huxley says :

"From the point of view of the moralist the animal world is on about the same level as a gladiator's show. The creatures are fairly well treated, and set to fight-whereby the strongest, the swiftest, and the cunningest live to fight another day. $* * *$

"In the cycle of phenomena presented by the life of man, no more moral end is discernible than in that presented by the lives of the wolf and of the deer. $* * *$

"As among these, so among primitive men, the weakest and stupidest went to the wall, while the toughest and shrewdest, those who were best fitted to cope with their circumstances, but not the best in any other sense, survived."

The infuriated savage may be cruel to his enemies, 
but we must not forget that the fury with which he takes up the combat is prompted by the love of his wife and child, or of his whole tribe, and the rise of mankind would not have taken place without a growth of the more refined sentiments of sympathy, kindness, and love. Professor Huxley undervalues the use of morality in the struggle for existence. Man survived not because of his toughness, or his shrewdness, but because of his moral qualities. The antediluvial fox was perhaps shrewder, and the lion or bear tougher, than the prehistoric savage or man-ape; but they were lacking in the social attachment which binds single individuals together with the ties of love, of family, and of friendship. Moral feelings, or rather the capacity and conditions of the growth of moral feelings, the tendency to reveal moral qualities, is not absent in the higher animals, especially mammals, and among mammals the several species of apes.* Attachment to others of their own kind makes animals gregarious and primitive man sociable. A social animal develops more morality than solitary beings, and the shrewdness of a social being becomes intelligence.

Intelligence is more powerful as a weapon in the struggle for existence than shrewdness, because it does not lack in morality ; it is more in unison with the cosmic order. Human speech is the product of intelligence and not of shrewdness. Man was able to develop speech only because he was moral enough to be social, and this morality elevated man above the rest of the animal world. Among savage tribes the most intelligent and not the shrewdest survived.

It is an undeniable fact that in any given district the tribes who were lacking in morality, even when the very shrewdest and toughest, had to go to the wall, while in the end the more moral remained victorious.

* Witness fur instance the affection of the monkey mother for her sick child in Landseer's famous painting. 
It is a wrong historical view to imagine that the Romans conquered the world because they were shrewder, stronger, and more ferocious than their neighbors. They

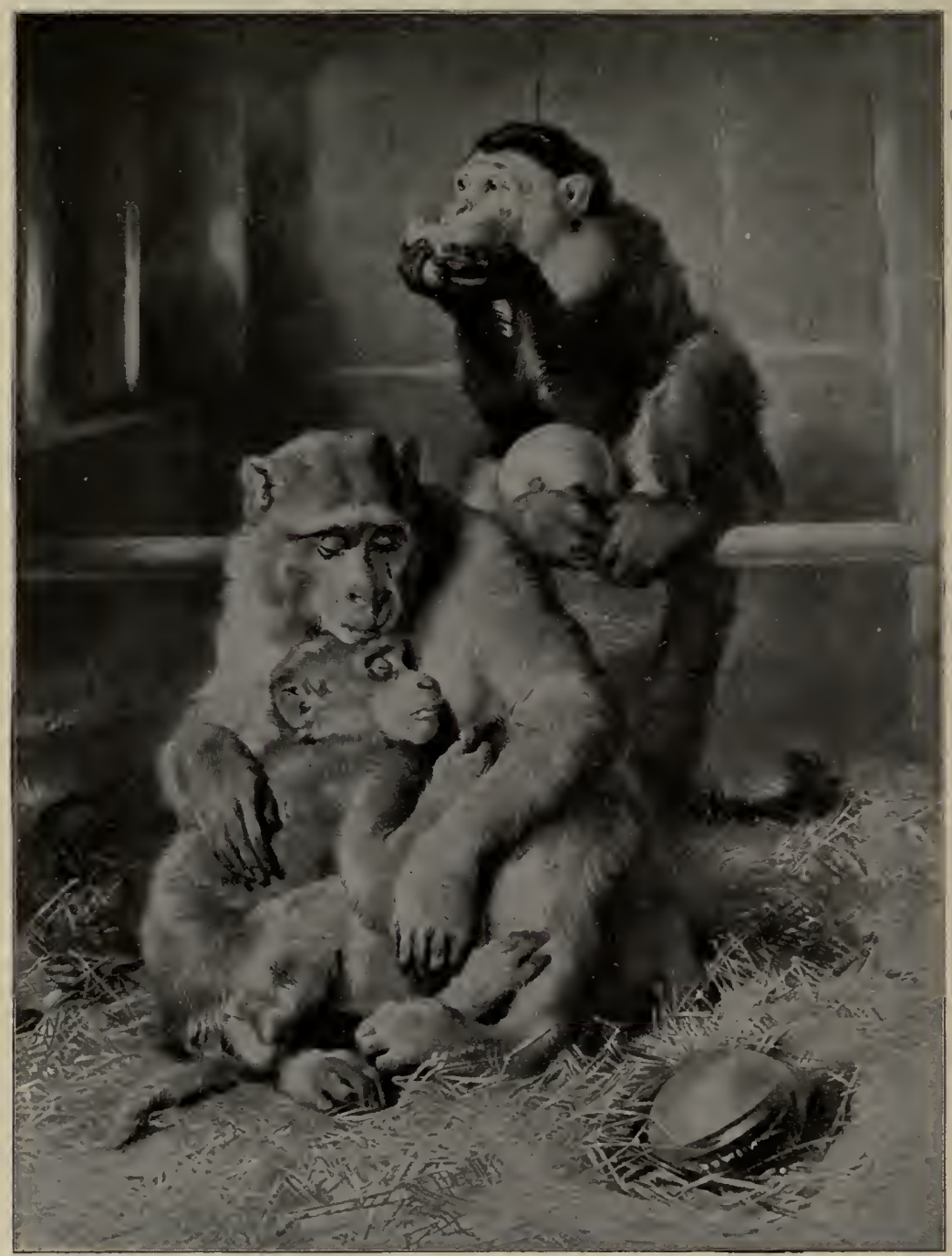

The Sick Monkey. (By Landseer.)

conquered the world because they possessed in addition to strength a rare moral quality-the quality of justice. With regard to their exercise of justice, indeed, they were 
by no means perfect; but they were more advanced, more moral and better in this respect than any other nation of their time, cultured Greece not excepted. Yet even the strength of the Romans was not the physical force of a ferocious bull; it was the moral strength of courage.

It will thus be seen that morality affords the power to survive, and if the primitive savage was not moral in the present acceptation of the word, he was in his time relatively the most moral being on earth, and this gave him more strength than toughness or shrewdness could ever afford.

Prof. Huxley declares in other passages of the same essay :

"The history of civilization - that is, of society-on the other hand, is the record of the attempts which the human race has made to escape from this position. $* * *$

"But the effort of ethical man to work toward a moral end by no means abolished, perhaps has hardly modified, the deep-seated impulses which impel the natural man to follow his non-moral course."

Professor Huxley adds with special reference to the civilization of the English nation of to-day :

"We not only are, but, under penalty of starvation, we are bound to be, a nation of shopkeepers. But other nations also lie under the same necessity of keeping shop, and some of them deal in the same goods as ourselves. Our customers naturally seek to get the most and the best in exchange for their produce. If our goods are inferior to those of our competitors, there is no ground compatible with the sanity of the buyers, which can be alleged, why they should not prefer the latter. And, if that result should ever take place on a large and general scale, five or six millions of us would soon have nothing to eat. We know what the cotton famine was; and we can therefore form some notion of what a dearth of customers would be.

"Judging by an ethical standard, nothing can be less satisfactory than the position in which we find ourselves. In a real, though incomplete, degree we have attained the condition of peace which is the main object of social organization (and it may, for argument's sake, be assumed that we desire nothing but that which 
is in itself innocent and praiseworthy-namely, the enjoyment of the fruits of honest industry). And lo! in spite of ourselves, we are in reality engaged in an internecine struggle for existence with our presumably no less peaceful and well-meaning neighbors. We seek peace and we do not ensue it. The moral nature in us asks for no more than is compatible with the general good; the nonmoral nature proclaims and acts upon that fine old Scottish family motto, 'Thou shalt starve ere I want.' Let us be under no illusion, then."

With all due respect to the facts presented by Professor Huxley, we must object to the conclusion at which he arrives. Professor Huxley's view of morals is based on the error that the wolf is immoral while the sheep is moral. The strong one is supposed to be an evil-doer, simply on account of his strength, while the weak one is supposed to be good simply on account of his weakness. Not the hero is glorified that "fights the good fight of faith," but the martyr that allows himself to be slaughtered without resistance.

This ethics has long been fostered by Christian moralists, because unfortunately Christ was compared to a lamb that is sacrificed, and because, in one of his allegories, Christ compares the good to sheep whom he will place at the right hand. The allegory is misinterpreted. It is neither the weakness nor the inactivity, but the purity of the sheep that is approved by Christ. How much is blamed, in another parable, the inactive and cowardly servant who buried the talent that was entrusted to him!

This ovine morality has detracted much of the pith and strength from Christian ethics. It has made it tame and weak and even despicable. Morality is not, as many lamb-souled moralists pretend, the negative quality of suffering; morality according to modern ethics is the positive virtue of energetic activity. Ours is, as the scientist correctly states, a struggle for existence ; and those who consider it meritorious to succumb to injustice and violence justly go to the wall. Their enemies, unjust though 
they may be, are comparatively more moral, for they are their superiors in the virtue of courage which gives them strength and power.

Prof. Huxley describes how the moralist, in the effort to restore harmony, tries to account for the iniquities in this world. He says :

"From the theological side, we are told that this is a state of probation, and that the seeming injustices and immoralities of Nature will be compensated by and by. But how this compensation is to be effected, in the case of the great majority of sentient things, is not clear. I apprehend that no one is seriously prepared to maintain that the ghosts of all the myriads of generations of herbivorous animals which lived during the millions of years of the earth's duration before the appearance of man, and which have all that time been tormented and devoured by carnivores, are to be compensated by a perennial existence in clover; while the ghosts of carnivores are to go to some kennel where there is neither a pan of water nor a bone with any meat on it."

This would indeed be a consistent consequence of a soft-brained and weak-hearted system of ethics, which praises the innocence and meritoriousness of mere suffering, and depicts as the ideal of morality a millennium of eternal peace, where the struggle for existence is unknown, where no labor nor painstaking is necessary and all time is spent in the glorification of an all-wise Creator.

Such a state of absolute perfection is impossible and we must smile at the ingenuousness of those philosophers who pretend to teach modern ethics and still adhere to the old millennium idea of a life of perfect adaptation where universal happiness will prevail.

The error in this Utopian idea is easily seen if we understand that the struggle for existence is inherent in nature. The struggle for existence is not only not in contradiction to ethics, it is on the contrary its most important factor, which must be taken into consideration and is taken into consideration by the monistic view of ethics. The old ethical view demands that man shall not resist 
evil ; that he shall leave off fighting and humbly allow himself to be trodden under foot. But the ethics of monism does not make man unfit for life, it renders him fitter in the struggle for existence. It teaches that so long as we are in harmony with the One and All of nature, so long as we remain in accord with natural laws, we shall be best able to resist evil. And this we can only do by constantly exercising our faculties and strengthening brawn and brain for the continued struggle,-which will cause us, it is true, much trouble and uneasiness, but at the same time will raise us to a higher level; it educates us and erhances the work of our existence.

Professor Huxley's scathing criticism is only justified if applied to the ovine morality of those who see a virtue in sheepishness. Humanity, Christian and anti-Christian, is under the influence of the sheep allegory still. But the struggle for existence will continue, it can not be abolished because it is a natural law, and sheepishness will never triumph in the world of real life.

Morality is not negative, it is not mere submission to evil, no pure passivity, no suffering, simply : morality is positive. Not by the omission of certain things do we do right, but by straining all the faculties of mind and body to do our best in the struggle for life which we have to fight. We may be weak, and we may feel our weakness. The greater should our efforts be, to fight the struggle ethically. We may be poor in spirit and we may feel our want, but nature will supply us with that which we want, if we but earnestly struggle to acquire it. $\mathrm{He}$ who is strong in spirit and in body, he who feels his strength and misuses it, will not be the conqueror in the end. It is not the self-sufficient that are blessed; but those who are aware of their insufficiency. This only, in my opinion, can be, or at least ought to be, the meaning when Christ says : 
"Blessed are the poor in spirit: for theirs is the kingdom of heaven."

We must be on our guard against unfeelingsternness, yet on the other hand let us not drop into the other extreme. We must be on our guard against ethical sentimentality also. There is too much preaching about the sweetness of religion and the rapturous delight of ethics. Yet this saccharine religiosity is just as impotent and useless as that ovine morality which glorifies in its weakness and does not struggle for strength.

Austere rigidity in religion and ethics is like a rose without odor, it is life without gladness, and obedience without loving devotion. The passivity of a lamb-like submission is idealized weakness fortified and strengthened by moral vanity and sugared over with sentimental enthusiasm.

Religion and ethics, we do not deny, are full of sweetness and noble joys, yet at the same time they are stern; they are of an unrelenting severity and majesty. It is only the unison of both, the strength of austerity and the fervor of sentiment, that makes morality wholesome, sound, and healthy.

The moral law is a natural law, it may be contrasted to, but does not stand in contradiction with, the other natural laws of a lower order. The deeper we investigate the more we shall be convinced that benefits acquired by injustice will prove to be injurious in the end : very often they are even the beginning of the ruin. Truth and justice are the most powerful weapons in the struggle for existence. Truth and justice will always conquer in the end. It often takes more time than the life of a single individual to see the triumph of truth; but we can be sure, even if the defenders of truth and justice die, if they succumb to their immoral enemies, that truth and justice will survive.

It is the belief in truth and justice which lies at the 
bottom of all religious and ethical views, and it is justified in both the realm of natural science and in the history of mankind.

In one sense, we can say man is throughout self-made. $\mathrm{He}$ had to climb the ladder of evolution, and every one of his bodily and mental qualities is acquired by himself. But in another sense, we can say that man is nothing by himself ; nature has made him. She led him step by step to find that which alone made him what he is-a rational

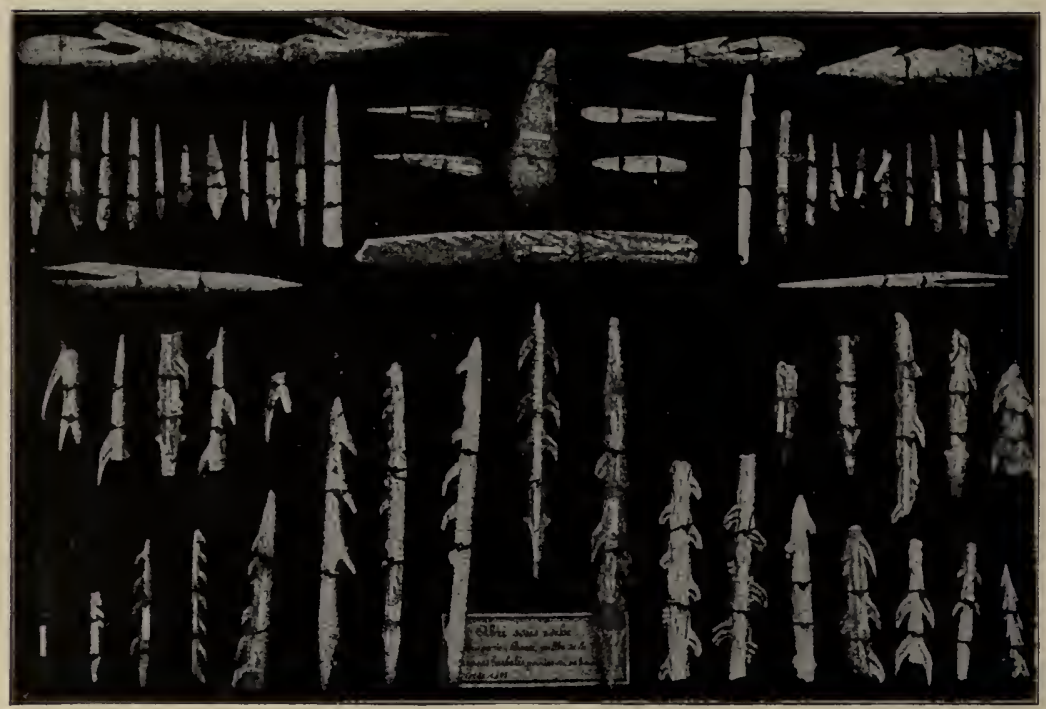

ARROW-HEADS AND HARPOONS OF REINDEER BONES FROM LAUGERIEBASSE. 3861 Originals in Musée du Jardin des Plantes, Paris. (Weltall und Menschheit, II, 272.)

being, a tool-making creature. Those who deviated from the path prescribed by nature, were hopelessly doomed to extinction. The path is prescribed in general outlines only; it admits of infinite variations in all its details, but certain general conditions are rigid and do not allow of any deviation.

The history of inventions represents a ladder on which we can always reach only to the next rung. The 
possibility of making each step is, upon the whole, definitely determined by the laws of existence.

Nature leads man onward, as it were, step by step, as if she pursued a special and well-calculated method of education. The mechanical contrivances to be invented

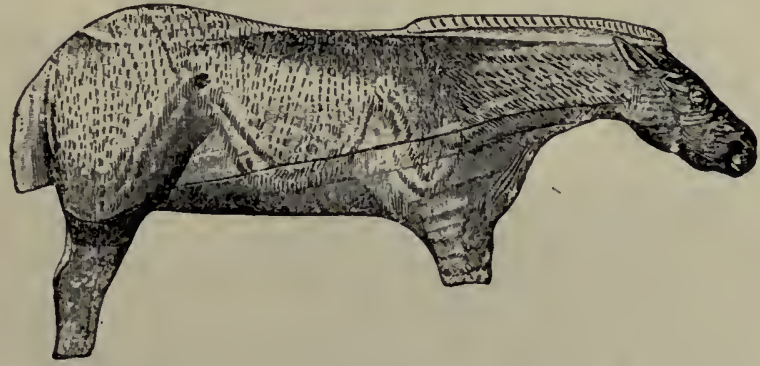

Bone carving from a diluvial station in Southern France. After Piette (Weltall und Menschheit, II, 280.)

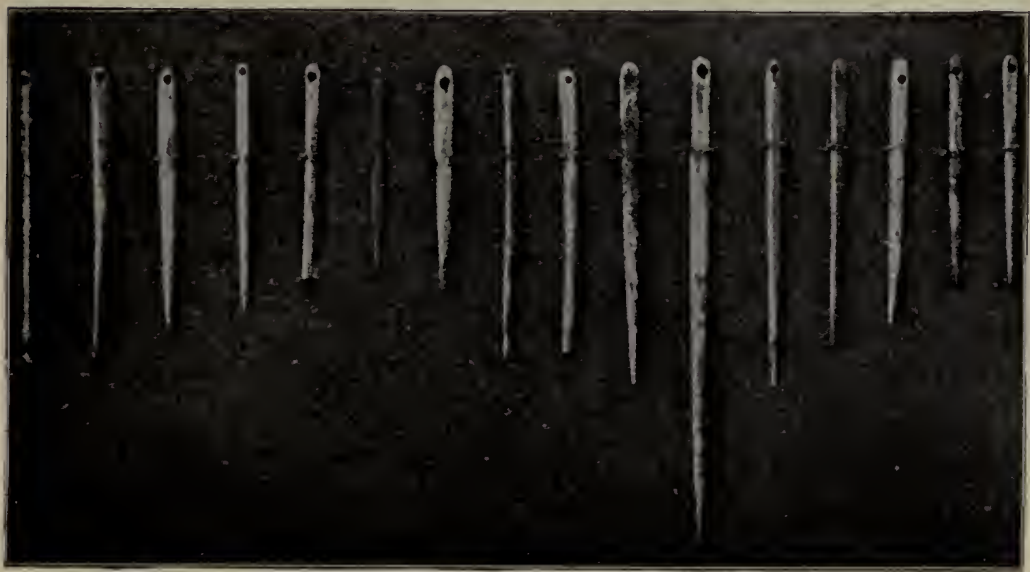

SEWING NEEDLES OF BONE SPLINTERS IN THE BRITISH MUSEUM (Weltall und Menschheit, II, 274.)

are suggested by our surroundings, and man finds them as soon as he reaches a stage of maturity that enabies him to detect them.

The earliest inventions are the best evidences of the fact that nature herself made the first inventions possible 
to man. The invention of pottery, for instance, apparently came about by attempts to heat liquid food in drinking vessels, such as skulls and gourds. When exposed to heat the vessels began to burn, and to protect them against the fire they were covered on the outside with clay. There can be no doubt that for a long time vessels to be used for cooking were such clay-covered skulls and gourds, for great numbers of them have been found in various

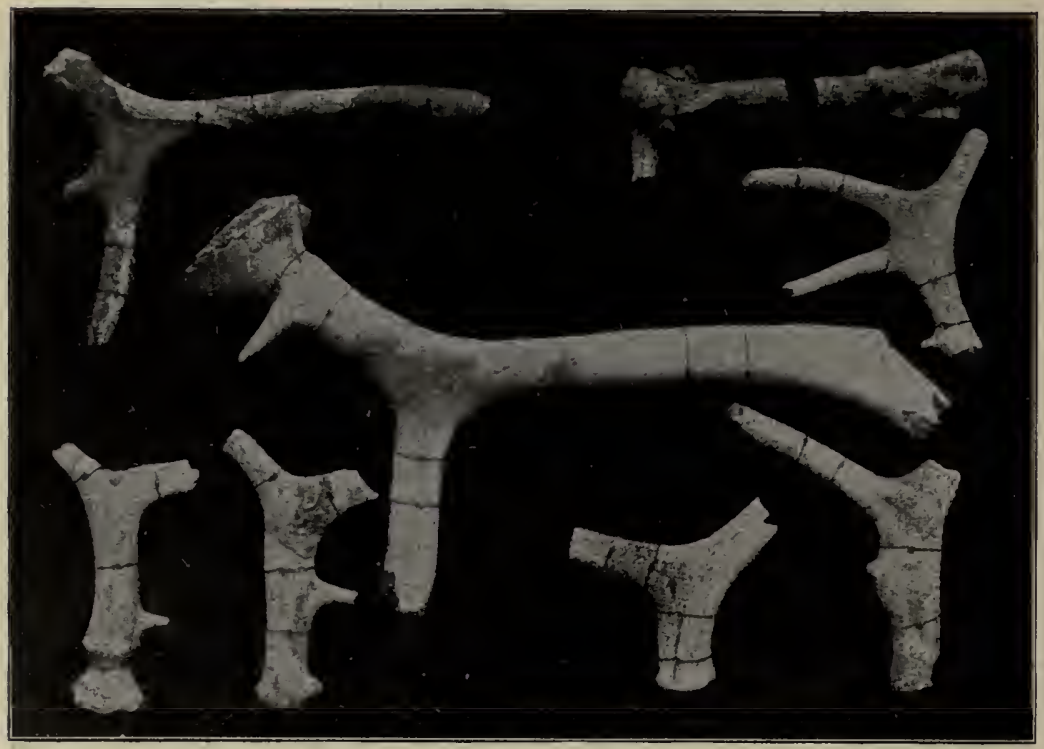

REINDEER BONES MADE INTO IMPLEMENTS.

3876

From the Musée du Jardin des Plantes, Paris. (Weltall und Menschheit, II, 27I.)

districts which testify to this fact. That the skull or gourd was not an essential part of the cooking vessel was perhaps, as we say, accidentally discovered, i. e., not by forethought or reflection through a process of reasoning, but simply through the actual experience that the gourd within the clay rotted away or wore off, while the clay cover not only remained serviceable but proved superior to other vessels that still contained their gourds. And 


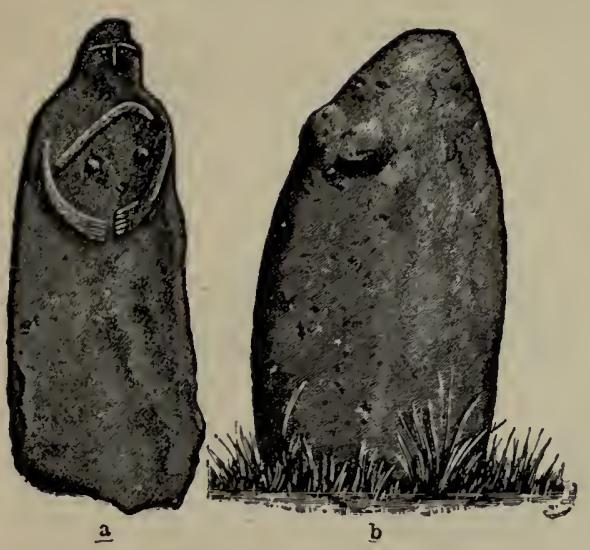

a. StONe of COllorgues; b. SARDinian MENHIR.

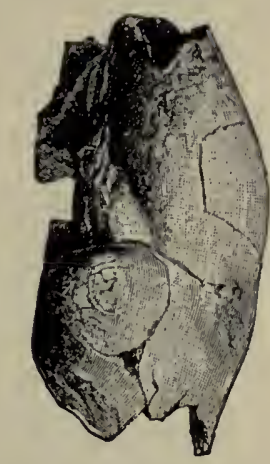

Venus of Brassempouy. After Piette.
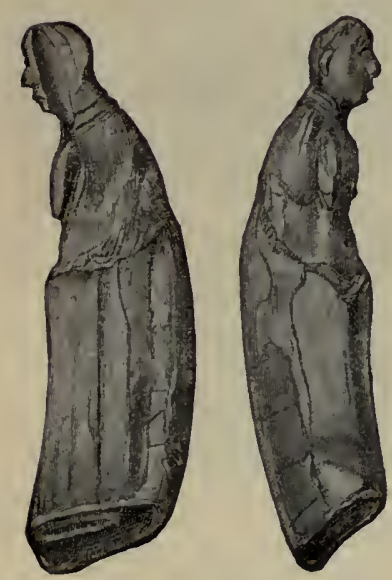

Human Figure Carved from 4960 A HORSE'S TOOTH.*
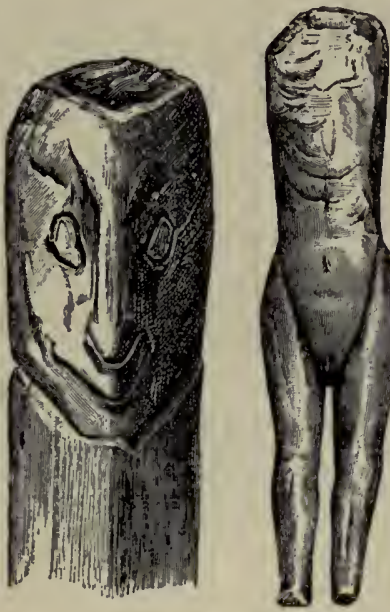

Human Figures of IVORY AND BONE.

After Müller and Cartailhac.

* This cut is reproduced from Weltall und Menschheit, and the others on this page from Woermann's Geschichte der Kunst. 
thus the pot was invented not by the wisdom of man but by nature, who, as it were, taught him the object lesson ; and man's merit consists only in having attained through previous object lessons the ability to understand the lesson.

How long it sometimes took men to learn a lesson taught by nature is difficult to say. But certain it is that

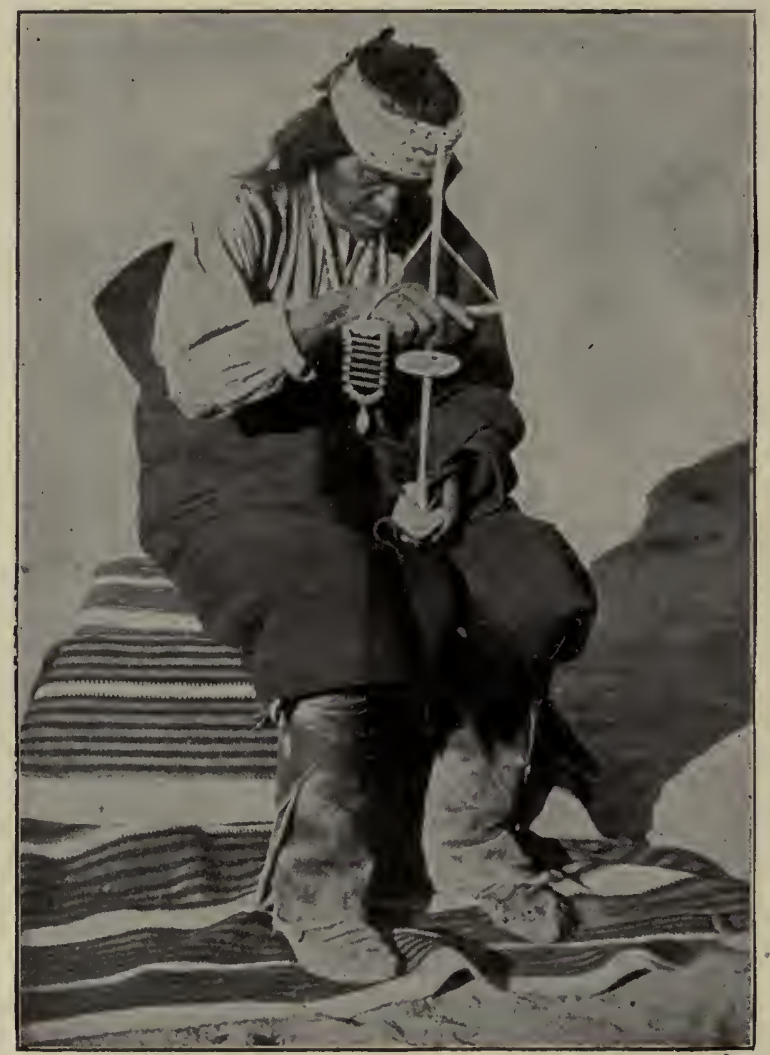

An American Indian Making Fire.

even to-day all inventions are made in the same way. Nature teaches the lesson, and we are her disciples. The higher we rise, the more quickly we can climb; and this produces the impression that we could climb in any direction we please; but we can not, and our inventive gen- 
iuses are only the better disciples of nature, our great and kind teacher.

While we may fairly well assume that the ancestors of the human race must have been fierce in battle and presumably wilder than the savages of Australia and Africa, we have good reason to believe that the first dawn of humanization was not without many redeeming features of humaner qualities. The age of primitive man must, at any rate, have been an interesting era stirred by a peculiar intellectual activity. What a miracle must have been the first appearance-or shall we say accidental invention-of firemaking, produced while boring holes with a hard stick in soft wood. So many relics of artifacts, art representations as well as utensils of most ancient date have been discovered, that some anthropologists speak of this period as a first efflorescence of the arts, and we may fairly well assume that there were among this primitive race of ape-men quite a number of geniuses, both inventors and artists. A review of the fragments discovered in many places shows that in hours of leisure their imagination prompted them to represent objects uppermost in their minds. They drew pictures of the mammoth which they hunted, of the reindeer, of the cave-bear, fish, bison, and the horse. They sculptured ornamental staves, the use of which has not yet been determined, though they may have served the purpose of scepters. They made needles of bones, fashioned horns of the reindeer into hammers, and from flint produced arrow-heads and knives. It is peculiar that no figure of man either carved or drawn has been discovered, but there are several sculptured women which are for plausible reasons supposed to belong to the very oldest relics of human art. One of them, very awkwardly carved and scarcely recognizable as a woman's form, is called the Venus of Brassempouy. Another female torso belonging to the Collection de Vibraye at Paris, and now in the National Museum there, was found in 
Laugerie Basse, but there are no records to tell whether it served as a doll or represented a goddess to be used for purposes of worship.
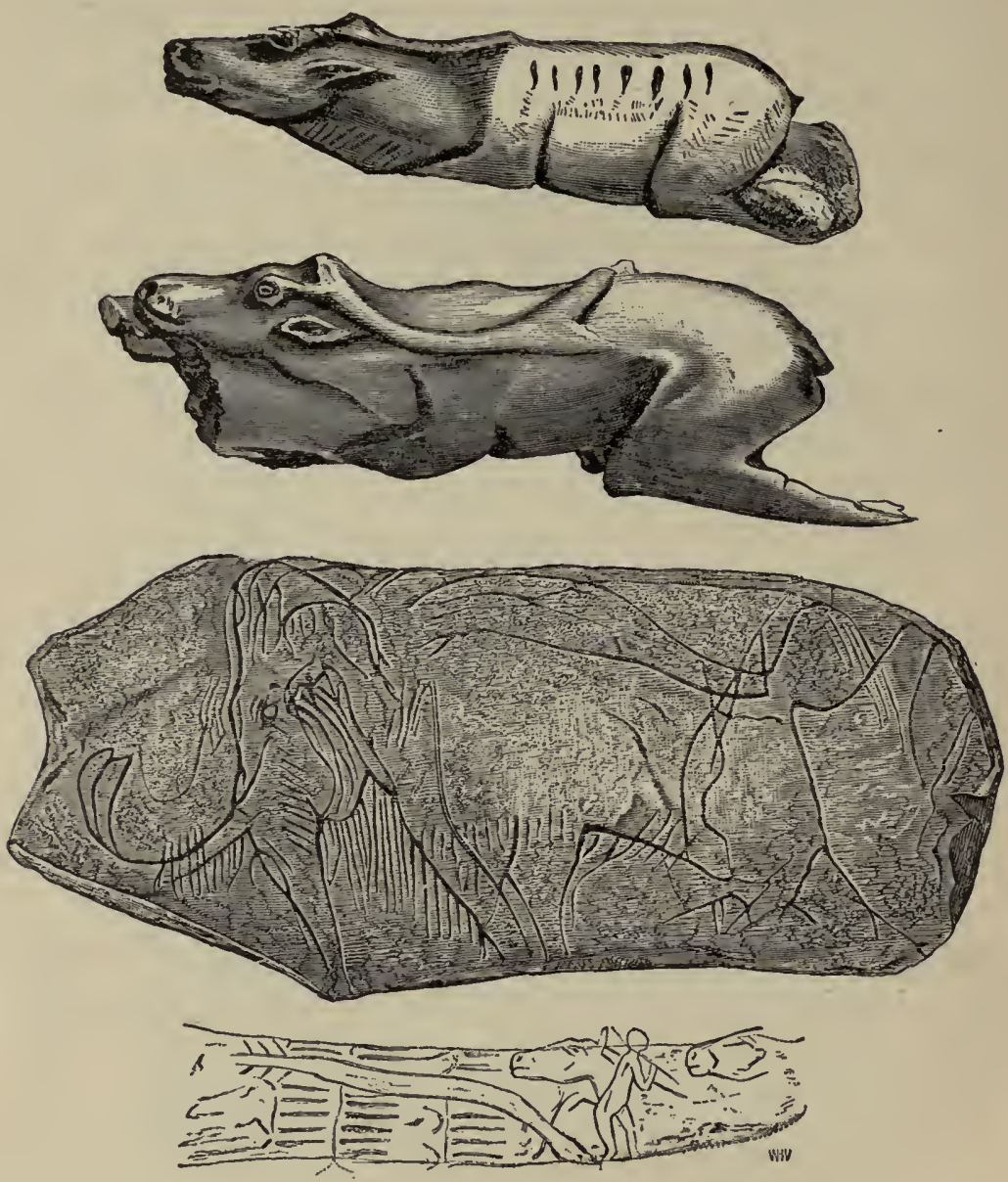

Prehistoric Carvings in Ivory and Horn.

After Lartet and Christy's Reliquiae Aquitanicae, and Dr. Hamy. (Lenormant's /fistoire ancienne de l'orient, I, I42.)

In spite of the ferocious character of primitive man, we have no reason to believe that he was under all conditions dangerous and beastlike. On the contrary there is 
no fact that would prove him to have been less kindly dispositioned than such highly advanced animals, as the elephant, the St. Bernard dog, or even the bear. Primitive man must have been social by nature, for the origin of humanity is due to communal life. .Language has developed through the desire and want of intercourse, through the need of an excliange of thought caused by communal life, communal labor, communal interests, all of which presuppose a social disposition, which would be impossible without the qualities of friendly and kindly sentiment. This humane feature in primitive man has not yet been sufficiently recognized, although it must have been the most significant factor in the origin of the human race.

Man's origin is due to a rise, not a fall; nor has the ascent been made by foul means. The prize has been fairly won. Civilization is not brought about by an oppression of the weak, or by fraud and rascality. It is the product of honest work ; of a bard yet fair struggle, and of noble aspirations. 



\section{INDEX.}

Acquired characteristics, 6I.

Animals, Domestication of, 76 .

Ant communities, 6I.

Anthropogenesis, School of, 72 ; Steps

of, 74 ; stopped by civilization, 77 .

Anthropoid Apes, $15 \mathrm{ff}$.

Ape-man, I3-I4; and man-ape, 42,

72 ; of Java, 4I, 56; Omnivorcus, 34 .

Arrow-heads, 86.

Australian, Picture of, 38; Skull of, 39.

Auswickelung, 6.

Baer, Von, 5.

Bee hives, 6r.

Best, Fittest not always the, 7-8.

Bible, 2.

Bone carved horse, 87 .

Brain development, 69; Curve of, 75 ; Rapid evolution of, 68; Survival of the, 70 .

Brehm, 26.

Broca, 5I.

Brux, 44.

Buddhism, 66.

Cannstatt, 44 .

Catarrhines, 36.

Caveman, Age of, 70; Home of the, $7 \mathrm{I}$.

Chicken and egg, 6.

Chimpanzee, 16, $27 \mathrm{ff}$; Pictures of, 29, 30, 3I, plates IV-VI, facing pp. $27,28,29$.

Christ, I3; compared to a lamb, 82.

Christianity, 66.

Civilization, continued good times,
68 ; Curve of, 75 ; a new factor, 65 ; preserves the unfit, 68 ; Weak points of, 66 .

Communal life, 93.

Comparisons are odious, 15.

Complexity, 8-9, I2.

Copernicus, II.

Criterion of Progress, 8-9.

Crocodile, 20.

Cro-Magnon type, 56, 73 .

Darwin, I, 3, 6, I4, 50.

Davis, J. Bernard, 50.

Degeneration of the little toe, 62 .

Dingo, 38.

Dispositions, 6.

Divine, I2.

Domestication of animals, 76 .

Du Bois, Professor, 53, 54, 55.

Du Chaillu, 26.

Duckbill, 38.

Ecclesiastes, 2.

Economy of thought, II.

Edwards's Zoological Exhibition, plates I-VI, facing pp. 20-2I, 26-29.

Egg and chicken, 6.

Egisheim, 44.

Elimination and expansion, 63 .

Entrickelung, 6.

Epigenesis, 6.

Europe, Central, 37.

Evolution accepted, I, 3; Meaning of, 9 ; a wrong word, 5 .

Expansion and elimination, 63 .

Feelings, Meaning of, ro; not mechanical, 9-Io.

Firemaking, by boring holes, 90, 9I. 
Fittest, not always the best, 7-8.

Fraipont, 44.

Friedenthal, $27 \mathrm{f}$.

Fuhlrott, 49, 50.

Function, 6I.

Gentile interpretation, 2.

Gibbon, 35 .

God, no begetter, 2 ; or nature, $\mathbf{I} 2$.

God-idea, II.

God's offspring, I.

Goethe, 5 .

Good and hard times, $63 \mathrm{ff}$.

Gorilla, I6; Description of, $20 \mathrm{ff}$;

Pictures of, 21, 23, 24, 25, 26; vegetarian, 24.

Greek quotation, I.

Haeckel, I8, 58.

Haller, 5.

Hamy, 52.

Hanno, 24ff.

Heaven, Kingdom of, I3.

Herculaneum, 54 .

Horse, Bone carved, 87 .

Hulock, 34, 35 .

Huxley, 5I, 78, 8I, 82, 84 .

Immaterial, The, 12.

Intelligence and shrewdness, 79.

Jaw-bone of Naulette, 52 .

Joe and Sallie at home, plate vi, facing p. 29.

Joe, the Chimpanzee, plates IV and v, facing pp. $27,28$.

Joe, the orang-utan, plates I and II, facing pp. 20, $2 \mathrm{I}$.

Joseph, St., 60.

Kangaroo, 38.

Kant-Laplace hypothesis, 9-Io.

Kepler, I I.

Kingdom of Heaven, I3.

Klaatsch, H., I6, 37.

Krapina cave, 54, Fossils from, 58.

Lamarck, 5 .

Lamarckian school, 6I.

Language and reason, 7 .

Lar, 34 .
Lemuria, 37.

Lhoest, 44 .

Life grows upward, 13.

Longfellow, 2 .

Madonna paintings, 60 .

Mammoth, Fighting the, 67 .

Man, Genesis of, in the pliocene period, 72; Unique position of, 3 .

Man-ape, 37, $40 \mathrm{f}$; and ape-man, 42, 72.

Maoris, 69.

Marsh, 74 .

Materialism, 9.

Max, Gabriel, $58 \mathrm{ff}$; Madonna of, 59 .

Mediterranean race, 73 .

Mesolithic, 74, 76 .

Missing link, I4.

Mitchell, Guernsey, 48.

Mohammed, 2.

Monotheism, Rigid, I.

Morality in the struggle for existence, 79; power to survive, $8 \mathrm{I}$.

Morgan, C. Lloyd, 64, 65.

Nature needs man, 87 ; or God, 12; whipping man onward, $4 \mathrm{r}$.

Neanderthal man, 43 ff., 73 .

Neolithic period, 74, 76 .

Omnivorous, ape-man, 34; Man, 40.

Orang-utan, Derivation of, I6; Description of, I7-20; Pictures of, I5, I7, I9, plates I-III, facing pp. 20, 2I, 26.

Ostrich-farming, 65 .

Ovine morality, $82,84,85$.

Paleolithic, 74.

Panmixia, 63.

Paul, Apostle, 2.

Pinkard, 27.

Pithecanthropus, I3 - I4, 53 ff., 72 ; erectus, Cranium of, 55 ; Relics of, 57.

Pliny, 26.

Pliocene Period, Genesis of man in the, 72.

Pompeii, 54.

Prichard, 5I.

Proboscis-monkey, $35 \mathrm{f}$. 
Progress, 4I ; Criterion of, 8-9.

Ptolemaic system, II.

Quatrefage, De, 52.

Race-memory, 6.

Rats, South Kensington, 64 .

Reason, 5, I2; and language, 7.

Reed, Dr. G. A., 69.

Reindeer bone instruments, 88 .

Rise to higher life, 60 .

Saccharine religiosity, 85 .

Saint-Hilaire, Geoffrey, 5 .

Schötensack, 39 .

Schüssler, 27.

Schwalbe, G., 44.

Serum of chimpanzee, 28.

Sewing needles, 87 .

Shrewdness and intelligence, 79.

Sick monkey, The, 8 o.

Sidney, Slab of Museum at, 37 .

Simplicity, I I

Skeletons of anthropoids, I8; of man and gorilla, 22.

Skull of Australian, 39.

Slab of Museum at Sidney, 37.

Sonship, Divine, 4, I3.

Soul-forms, IO-I I.

South Kensington rats, 64 .

Spencer, Herbert, 8, 9.
Spy, 44; Skeletons of, 73; Skull of. 53.

Survival, not always progress, 8 .

'Teacher's story, 3 .

Teeth of man and ape, $35 \mathrm{f}$.

Test of progress, Truth, II.

Times, Good and hard, $63 \mathrm{ff}$.

Toe, Degeneration of the little, 62 .

Topinard, Paul, 52.

Treviranus, Gottfried Reinhold, 5 .

Truth and justice, Belief in, 85; not made of dust, I2; test of progress, I I-I 2 .

Uniformities, 7 .

Unique position of man, 3 .

Upward, Life grows, I3.

Utopian idea, 83 .

Vegetarian, Chimpanzee, 28; Gorilla, 24.

Venus of Brassempouy, 89, 9

Virchow, 43.

Ward, Charles H., 49.

Ward, Henry A., 48.

Warnambool, 38

Weak points of civilization, 66 .

Weismann, 61, 62, 63 .

Wolf, Kaspar Friedrich, 5 .

Woodruff, Dr. Charles E., 66, 70, 74 

Plant Breeding Comments on the experiments of Hugo DeVries, Professor of Botany in the University of Amsterdam.

Pages, XIII + 351. 114 Illustrations. Printed on fine enamel paper. Cloth, gilt top, $\$ 1.50$ net; $\$ 1.70$ postpaid. (7s. 6 d. net.)

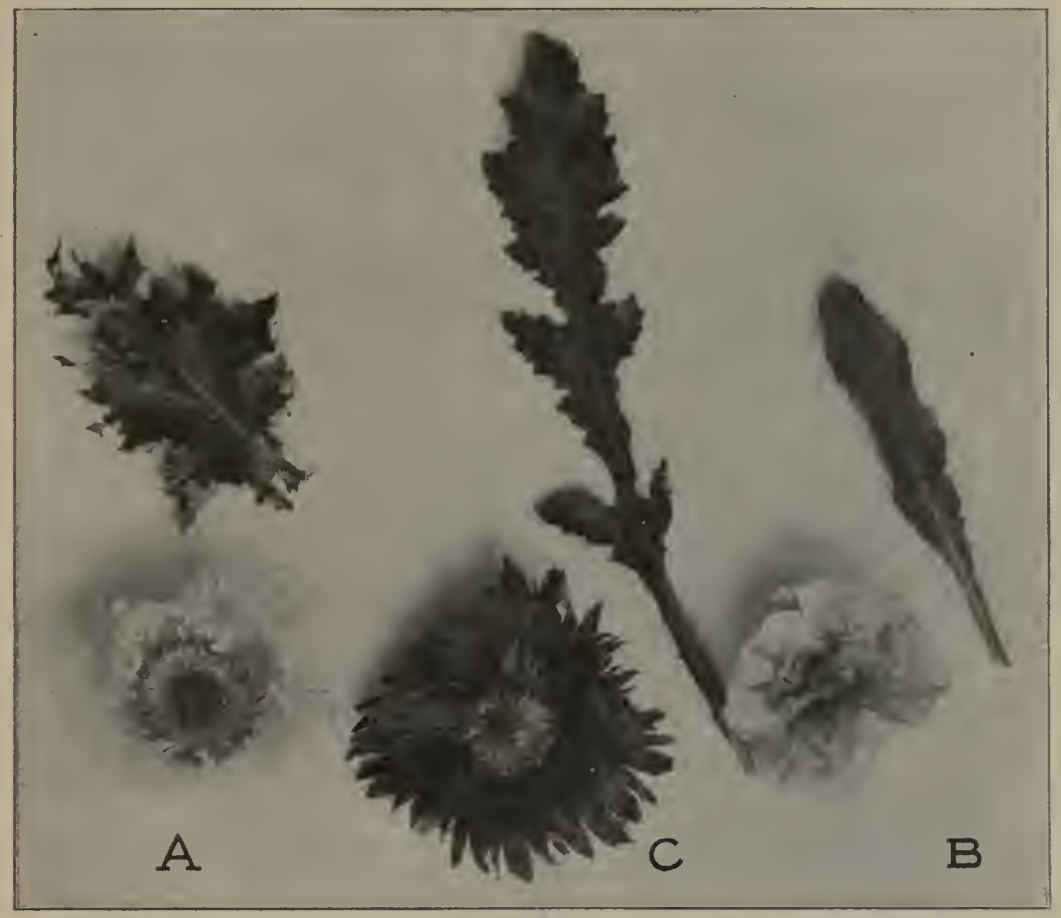

Under the influence of the work of Nilsson, Burbank, and others, the principle of selection has, of late, changed its meaning in practice in the same sense in which it is changing its significance in science by the adoption of the theory of an origin of species by means of sudden mutations. The method of slow improvement of agricultural varieties by repeated selection is losing its reliability and is being supplanted by the discovery of the high practical value of the elementary species, which may be isolated by a single choice. The appreciation of this principle will, no doubt, soon change the whole aspect of agricultural plant breeding.

Hybridization is the scientific and arbitrary combination of definite characters. It does not produce new unit-characters; it is only the combination of such that are new. From this point of view the results of Burbank and others wholly agree with the theory of mutation, which is founded on the principle of the unit-characters.

This far-reaching agreement between science and practice is to become a basis for the further development of practical breeding as well as of the doctrine of evolution. To give proof of this assertion is the main aim of these Essays.

The results of Nilsson have been published only in the Swedish language; those of Burbank have not been described by himself. Prof. DeVries's arguments for the theory of mutation have been embodied in a German book, "Die Mutationstheorie" (2 vols. Leipsic, Vat \& Co.), and in lectures given at the University of California in the summer of 1904 , published under the title of "Species and Varieties; their Origin by Mutation." A short review of them will be found in the first chapter of these Essays.

Some of them have been made use of in the delivering of lectures at the Universities of California and of Chicago during the summer of 1906 and of addresses before various audiences during my visit to the United States on that occasion. In one of them(II.D.), the main contents have been incorporated of a paper read before the American Philosophical Society at their meeting in honor of the bicentennary of the birth of their founder, Benjamin Franklin, April, 1906. 


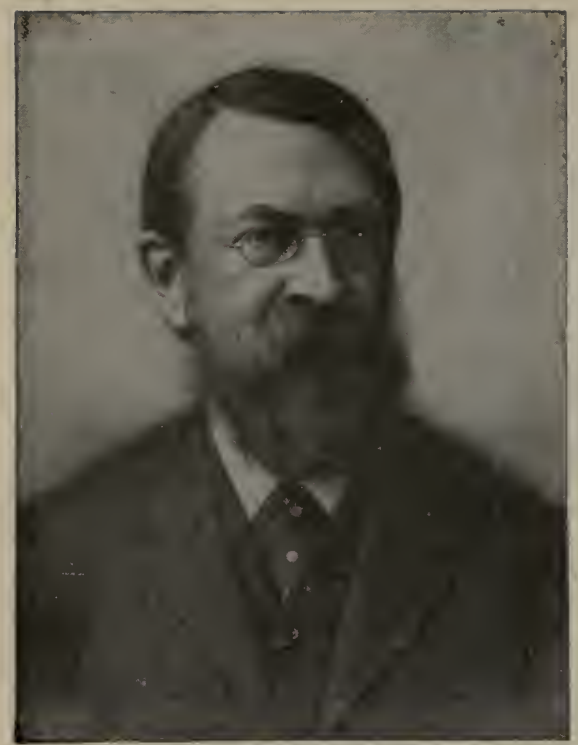

Space and Geometry in
the Light of Physiolog-
ical, Psychological and
Physical Inquiry. By

Dr. Ernst Mach, Emeritus Professor in the University of Vienna. From the German by Thomas J. McCormack, Principal of the LaSalle-Peru Township High School. 1906. Cloth, gilt top. Pp. 143. \$1.00 net. (5s. net.)

In these essays Professor Mach discusses the questions of the nature,origin, and development of our concepts of space from the three points of view of the physiology and psychology of the senses, history, and physics, in all which departments his profound researches have gained for him an authoritative and commanding position. While in most works on the foundations of geometry one point of view only is emphasized-be it that of logic, epistemology, psychology, history, or the formal technology of the science-here light is shed upon the subject from all points of view combined, and the different sources from which the many divergent forms that the science of space has historically assumed, are thus shown forth with a distinctness and precision that in suggestiveness at least leave little to be desired.

Any reader who possesses a slight knowledge of mathematics may derive from these essays a very adequate idea of the abstruse yet important researches of metageometry.

The Vocation of Man. By Johann Gottlieb Fichte. Translated by William Smith, LL. D. Reprint Edition. With biographical introduction by E. Ritchie, Ph. D. 1906. Pp. 185. Cloth, 75c net. Paper, 25c; mailed, 31c. (1s. 6d.)

Everyone familiar with the history of German Philosophy recognizes the importance of Fichte's position in its development. His idealism was the best exposition of the logical outcome of Kant's system in one of its principal aspects, while it was also the natural precurs $r$ of Hegel's philosophy. But the intrinsic value of Fichte's writings have too often been overlooked. His lofty ethical tone, the keenness of his mental vision and the purity of his style render his works a stimulus and a source of satisfaction to every intelligent reader. Of all his many books, that best adapted to excite an interest in his philosophic thought is the Vocation of Man, which contains many of his most fruitful ideas and is an excellent example of the spirit and method of his teaching.

The Rise of Man. A Sketch of the Origin of the Human Race.

By Paul Carus. Illustrated. 1906. Pp. 100. Boards, cloth back, 75 net. (3s.6d. net.)

Paul Carus, the author of The Rise of Man, a new book along anthropological lines, upholds the divinity of man from the standpoint of evolution. He discusses the anthropoid apes, the relics of primitive man, especially the Neanderthal man and the ape-man of DuBois, and concludes with a protest against Huxley, claiming that man has risen to a higher level not by cunning and ferocity, but on the contrary by virtue of his nobler qualities. 


\section{The Sermons of a Buddhist Abbot. Some Addresses on}

Religious Subjects by the Rt. Rev. Soyen Shaku, Abbot of Engakuji and Kenchoji, Kamakura, Japan. Translated by Daisetz Teitaro Suzuki. Pp. 218. Cloth. $\$ 1.00$ net. (4s.6d. net.)

The Sermons of a Buddhist Abbot, which were delivered by the Rt. Rev. Soyen Shaku, during the author's visit to this country in 1905-1906, and have been collected and translated and edited by his interpreter and friend,.Mr. Daisetz Teitaro Suzuki,

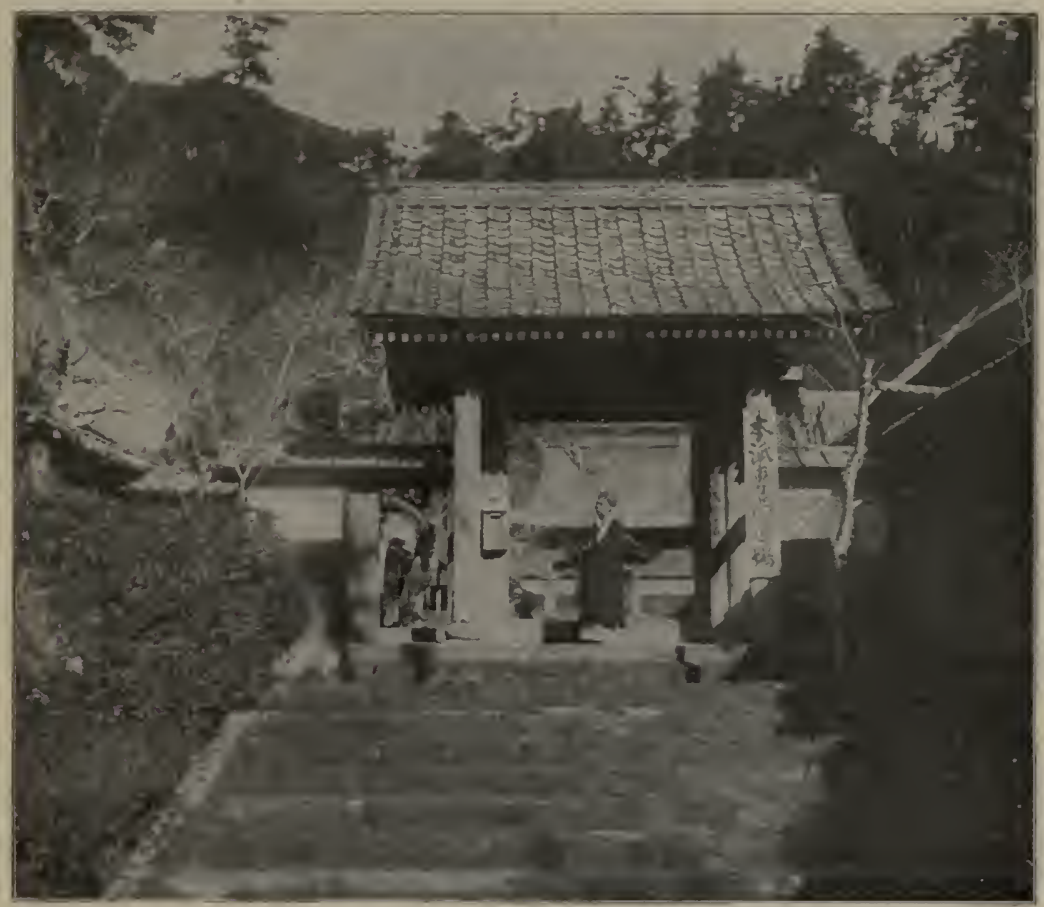

will prove fascinating to those who are interested in the comparative study of religion as well as in the development of Eastern Asia. Here we have a Buddhist Abbot holding a high position in one of the most orthodox sects of Japan, discoursing on problems of ethics and philosophy with an intelligence and grasp of the subject which would be rare even in a Christian prelate.

The Praise of Hypocrisy. An Essay in Casuistry. By G. T.

Knight, D. D., Professor of Christian Theology in Tufts College Divinity School. 1906. Pp. 86. 50c net.

"The Praise of Hypocrisy" is an essay based on the public confessions of hypocrisy that many champions of religion have made in these days, and on the defenses they have put forth in support of the practice of deceit. Not that the sects now accuse each other of insincerity, nor that the scoffer vents his disgust for all religion, but that good men (as all must regard them) in high standing as church members have accused themselves.

By exhibiting the implications and tendencies of the ethics thus professed and defended, and by sharp comment on the same, the author of this essay designs to arouse the conscience of the church, to sting it into activity in a region of life where its proper functions have ceased.

This is not an attack on the church, nor even a mere criticism; it is the language of righteous indignation hopefully summoning the church to be honest with itself, to be loyal and faithful to its master. 


\section{Essay on the Creative Imagination. By Prof.Th.}

Ribot. Translated from the French by A. H. N. Baron, Fellow in Clark University. 1906. Cloth, gilt top. Pp. 357. \$1.75 net. (7s.6d. net.)

Imagination is not the possession only of the inspired few, but is a function of the mind common to all men in some degree; and mankind has displayed as much imagination in practical life as in its more emotional phases-in mechanical, military, industrial, and commercial inventions, in religious, and political institutions as well as in the sculpture, painting, poetry and song. This is the central thought in the new book of Th. Ribot, the well-known psychologist, modestly entitled An Essay on the Creative Imagination.

It is a classical exposition of a branch of psychology which has often been discussed, but perhaps never before in a thoroughly scientific manner. Although

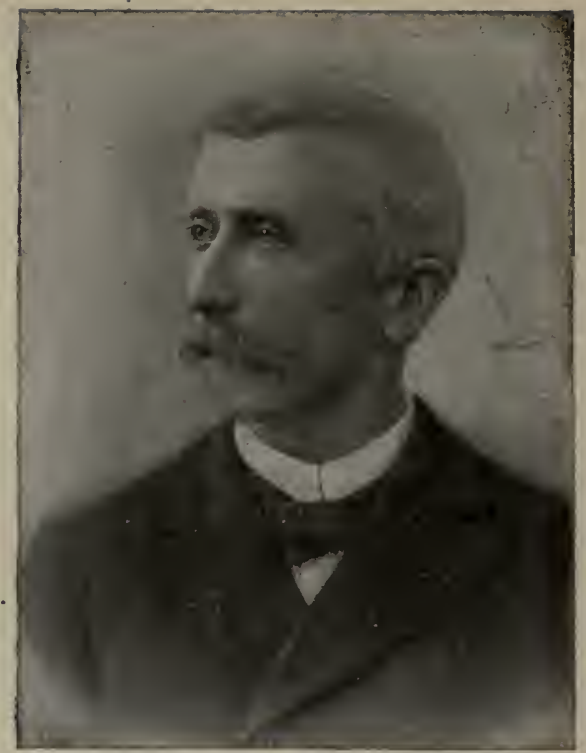
the purely reproductive imagination has been studied with considerable enthusiasm from time to time, the creative or constructive variety has been generally neglected and is popularly supposed to be confined within the limits of esthetic creation.

\section{Our Children. Hints from Practical Experience for Parents and}

Teachers. By Paul Carus. Pp. 207. $\$ 1.00$ net. (4s. 6d. net.)

In the little book Our Children, Paul Carus offers a unique contribution to pedagogical literature. Without any theoretical pretensions it is a strong defense for the rights of the child, dealing with the responsibilities of parenthood, and with the first inculcation of fundamental ethics in the child mind and the true principles of correction and guidance. Each detail is forcefully illustrated by informal incidents from the author's experience with his own children, and his suggestions will prove of the greatest possible value to young mothers and kindergartners. Hints as to the first acquaintance with all branches of knowledge are touched upon-mathematics, natural sciences, foreign languages, etc.-and practical wisdom in regard to the treatment of money, hygiene, and similar problems.

Yin Chih Wen, The Tract of the Quiet Way. With Extracts from the Chinese commentary. Translated by Teitaro Suzuki and Dr. Paul Carus. 1906. Pp. 48. 25c net.

This is a collection of moral injunctions which, among the Chinese is second perhaps only to the Kan-Ying P'ien in popularity, and yet so far as is known to the publishers this is the first translation that has been made into any Occidental language. It is now issued as a companion to the T'ai-Shang Kan-Ying P'ien, although it does not contain either a facsimile of the text or its verbatim translation. The original consists of the short tract itself which is here presented, of glosses added by commentators, which form a larger part of the book, and finally a number of stories similar to those appended to the Kan-Ying P'ien, which last, however, it has not seemed worth while to include in this version. The translator's notes are of value in justifying certain readings and explaining allusions, and the book is provided with an index. The frontispiece, an artistic outline drawing by Shen Chin-Ching, represents Wen Ch'ang, one of the highest divinities of China, revealing himself to the author of the tract.

The motive of the tract is that of practical morality. The maxims give definite instructions in regard to details of man's relation to society, besides more general commands of universal ethical significance, such as "Live in concord," "Forgive malice," and "Do not assert with your mouth what your heart denies." 
T'ai-Shang Kan-Ying P'ien, Treatise of the Exalted One on Response and Retribution. Translated from the Chinese by Teitaro Suzuki and Dr. Paul Carus. Containing Chinese Text, Verbatim Translation, Explanatory Notes and Moral Tales. Edited by Dr. Paul Carus. 16 plates. Pp. 135. 1906. Boards, 75c net.

The book contains a critical and descriptive introduction, and the entire Chinese text in large and distinct characters with the verbatim translation of each page arranged on the opposite page in corresponding vertical columns. This feature makes the book a valuable addition to the number of Chinese-English text-books already available. The text is a facsimile reproduction from a collection of Chinese texts made in Japan by Chinese scribes.

After the Chinese text follows the English translation giving references to the corresponding characters in the Chinese original, as well as to the explanatory notes immediately following the English version. These are very full and explain the significance of allusions in the Treatise and compare different translations of disputed passages. This is the first translation into English directly from the Chinese original, though it was rendered into French by Stanislas Julien, and from his French edition into English by Douglas.

A number of illustrative stories are, appended in all the editions of the original, but the selection of these stories seems to vary in the different editions. They are very inferior in intrinsic value to the Treatise itself, and so are represented here only by extracts translated in part directly from the Chinese edition and in part through the French of Julien, but many are illustrated by reproductions of the Chinese pictures from the original edition. The frontispiece is a modern interpretation by Keichyu Yamada of Lao Tze, the great Oriental philosopher, "The Exalted One" to whom the authorship of this Treatise is ascribed.

\section{Spinoza and Religion. A Study of Spinoza's Metaphysics and of}

his particular utterances in regard to religion, with a view to determining the significance of his thought for religion and incidentally his personal

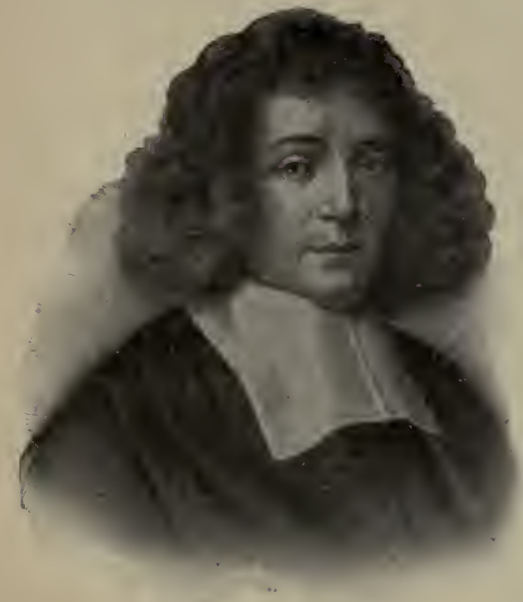
attitude toward it. By Elmer Ellsworth Powell, A. M., Ph. D., Professor of Philosophy in Miami University. 1906. Pp. xi, 344. \$1.50 net. (7s. 6d.)

Spinoza has been regarded for centuries as the inost radical philosopher, yet he had a reverential attitude toward religion and prominent thinkers such as Goethe looked up to him as their teacher in both metaphysics and religion. Professor E. E. Powell, of Miami University, feels that there has been great need to have Spinoza's philosophy and attitude toward religion set forth by a competent hand, and, accordingly, he has undertaken the task with a real love of his subject, and has indeed accomplished it with success. 


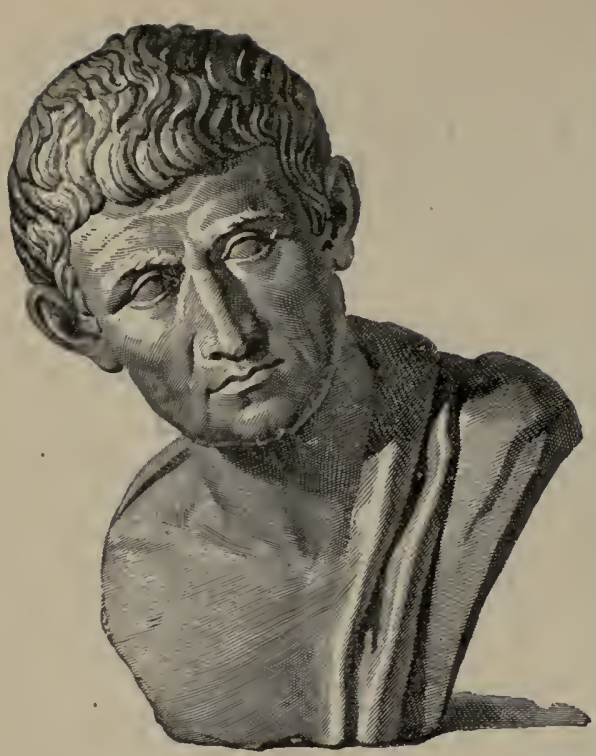

Aristotle on His Prede-

cessors. Being the first book of his metaphysics. Translated from the text of Christ, with introduction and notes. By A. E. Taylor, M. A., Fellow of Merton College, Oxford; Frothingham Professor of Philosophy in McGill University, Montreal. Pp. 160. Cloth, 75c net. Paper, 35c postpaid.

This book will be welcome to all teachers of philosophy, for it is a transla. tion made by a competent hand of the most important essay on the history of Greek thought down to Aristotle, written by Aristotle himself. The origina! served this great master with his unprecedented encyclopedic knowledge as an introduction to his Metaphysics; but it is quite apart from the rest of that work, forming an independent essay in itself, and will remain forever the main source of our information on the predecessors of Aristotle. Considering the importance of the book, it is strange that no translation of it appears to have been made since the publication of that by Bekker in 1831 .

The present translation has been made from the latest and most critical Greek text available, the second edition of W. Christ, and pains have been taken not only to reproduce it in readable English, but also to indicate the exact way in which the translator understands every word and clause of the Greek. He has further noted all the important divergencies between the readings of Clirist's text and the editions of Zellar and Bonitz, the two chief modern German exponents of Aristotelianism.

Not the least advantage of the present translation is the incorporation of the translator's own work and thought. He has done his best, within the limited space he has allowed himself for explanations, to provide the student with ample means of $\mathrm{judging}$ for himself in the light of the most recent researches in Greek philosophical literature, the value of Aristotle's account of previous thought as a piece of historical criticism.

\section{Zarathushtra, Philo, the Achaemenids and Israel.}

A Treatise Upon the Antiquity and Influence of the Avesta. By Dr. Lawrence H. Mills, Professor of Zend Philology in the University of Oxford. 1906. Pp. 460. Cloth, gilt top. $\$ 4.00$ net.

Professor Lawrence H. Mills, the great Zendavesta scholar of Oxford, England, has devoted his special attention to an investigation and comparison of the relations that obtain between our own religion, Christianity-including its sources in the Old Testament scriptures-and the Zendavesta, offering the results of his labors in a new book that is now being published by The Open Court Publishing Company, under the title, "Zarathushtra, Philo, the Achaemenids and Israel, a Treatise upon the Antiquity and Influence of the Avesta." We need scarcely add that this subject is of vital importance in theology, for the influence of Persia on. Israel and also on the foundation of the Christian faith has been paramount, and a proper knowledge of its significance is indispensable for a comprehension of the origin of our faith.

Babel and Bible. Three Lectures on the Significance of Assyriological Research for Religion, Embodying the most important Criticisms and the Author's Replies. By Dr. Friedrich Delitzsch, Professor of Assyriology in the University of Berlin. Translated from the German. Profusely illustrated. 1906. Pp. xv, 240. \$1.00 net.

A new edition of "Babel and Bible," comprising the first, second and third lectures by Dr. Friedrich Delitzsch, complete with discussions and the author's replies, has been published by The Open Court Publishing Company, making a stately volume of 25.5 pages.

THE OPEN COURT PUBLISHING CO., 1322 Wabash Avø., Chicago 


\section{The Story of Samson}

And Its Place in the Religious Development of Mankind.

By Paul Carus. 80 illustrations. Pp. 183. Comprehensive index. Boards, $\$ 1.00$ net. (4s. 6 d. net.)

Dr. Carus contends that Samson's prototype is to be found in those traditions of all primitive historical peoples which relate to a solar deity. He believes that genuine tradition, no matter how mythological, is more conservative than is at first apparent. Though the biblical account of Samson's deeds, like the twelve labors of Heracles, is the echo of an ancient solar epic which glorifies the deeds of Shamash in his migration through the twelve signs of the zodiac, there may have been a Hebrew hero whose deeds reminded the Israelites of Shamash, and so his adventures were told with modifications which naturally made the solar legends cluster about his personality.

References are fully given, authorities quoted and comparisons are carefully drawn between Samson on the one hand, and Heracles, Shamash, Melkarth and Siegfried on the other. The appendix contains a controversy between Mr. Geo. W. Shaw and the author in which is discussed at some length the relation between myth and history.

\section{Chinese Thought An Exposition of the Main Character- istic Features of the Chinese World-}

Conception. By Paul Carus. Being a continuation of the author's essay, Chinese Philosophy. Illustrated. Index. Pp. 195. \$1.00 net. (4s.6d.)

This book contains much that is of very great interest in the development of Chinese culture. Beginning in the first chapter with a study of the earliest modes of thought-communication among primitive people of different parts of the world, and tracing the growth of the present system of Chinese caligraphy. In "Chinese Occultism" some interesting Oriental mystical ideas are explained as well as the popular methods of divination by means of trigrams and the geomancer's compass. In a special chapter the zodiacs of different nations are compared with reference to the Chinese zodiac and also to a possible common Babylonian origin. This chapter contains many rare and valuable illustrations representing almost all known zodiacs from those of Egypt to the natives of the Western hemisphere. The influence of Confucius is discussed, and a hurried recapitulation of the most important points in Chinese history is given together with a review of the long novel which stands in the place of a national epic. Chinese characteristics and social conditions have their place in this volume as well as the part played in China by Christian missions, and the introduction of Western commercialism. The author's object is to furnish the necessary material for a psychological appreciation of the Chinese by sketching the main characteristic features of the ideas which dominate Chinese thought and inspire Chinese morality, hoping thereby to contribute a little toward the realization of peace and good will upon earth.

\section{Chinese Life and Customs $\underset{\text { Wyth illustrations }}{\mathrm{B} \text { Pal }}$}

by Chinese artists. Pp. 114. 75c. net. (3s. 6d. net.)

This book is little more than a compilation of Chinese illustrations accompanied with only as much text as will suffice to explain them, and what further material has been added is merely in the way of quotations from Chinese literature. The intention is to make the Chinese people characterize themselves by word and picture. Child rhymes, love lyrics and songs of revelry are introduced in translation from Chinese poetry which is recognized as classical. The illustrations which form the great body of the book are from the most authentic Chinese source of information concerning modern life in China unaffected by the aggressive Occidental foreigners. The book is divided into chapters on "Annual Festivals," "Industries and Foreign Relations," "Confucianism and Ancestor Worship," "Taoism and Buddhism," "Childhood and Education," "Betrothal and Marriage," "Social Customs and Travels," "Sickness and Death." 


\section{Our Children}

\section{Hints from Practical Experience for Parents and Teachers. By Paul Carus

\author{
Pp. 20\%. \$1.00 net. (4s.6d. net)
}

In the little book Our Children, Paul Carus offers a unique contribution to pedagogical literature. Without any theoretical pretensions it is a strong defense for the rights of the child, dealing with the responsibilities of parenthood, and with the first inculcation of fundamental ethics in the child mind and the true principles of correction and guidance. Wach detail is forcefully illustrated by informal incidents from the anthor's experience with his own children, and his suggestions will prove of the greatest possible value to young mothers and kindergartners. Hints as to the first acquaintance with all branches of knowledge are touched upon-mathematics, natural sciences, foreign languages, etc. - and practical wisdom in regard to the treatment of money, hygiene and similar problems.

\section{PRESS NOTICES}

"Brightly written, broad-minded, instructive, this book deserves serious perusal and praise." -CHICAGO RECORD-HERALD.

" 'Our Children' has a value which it is difficult to exaggerate. The strong common sense of the book as a whole can better be judged from an extract than from any praise of it, however particularized.

"It is difficult to conceive of anything coming up in relation of parent or teacher to a child which does not find discussion or suggestion in this compact and helpful little book. It will be an aid to parents and teachers everywhere-an education for them no less than for the child." -THE CHICAGO DAILY NEWS.

"From my own personal point of view I can only welcome this volume in our pedagogical literature and express the hope that it may become a household book in the library of every parent and teacher." M. P. E. GROSZMANN, Pd. D.,

Director Groszmann School for Nervous Children

"Mr. Carus writes in a most practical manner upon his subject, setting before the reader the various problems common to all parents in dealing with their offspring. This book is admirable throughout in the author's treatment of his subjects, as the book is built from the experiences of parents and teachers and, therefore, cannot fail to be practicable."

-THE BOSTON HERALD.

"For the training of children I know of no book in which there is so much value in a small compass as in this." -THE TYLER PUBLISHING CO.

"Little things are recommended that will appeal to the child's understanding and add to his interest in his work."

-CLEVELAND PLAIN DEALER

"Its author has given to the world a careful, loving, thoughtful set of rules which may be used with profit in the bringing up of the young." -THE MANTLE, TILE AND GRATE MONTHLY.

"We feel certain that any parent who thoughtfully reads and studies this book will be richly paid; and if the readers be parents with growing children they will keep the book by them for frequent consultation; not for iron rules but for sympathetic suggestion."

-THE COMMERCIA l. NEWS (Danville, IIl.)

"At once the reader knows that he is in touch with a mind that is accustomed to sincere and deep thinking. The whole book is a plea for a serious notion of parenthood. The author touches one topic after another with a fine sense of feeling for the 'warm spot' in it.

"The use of money, square dealing, worldly prudence, sympathy with animals, treatment of a naughty child, self criticism, and punishment, are some of the more important themes of the book." -THE SUBURBAN.

The Open Court Publishing Co., 1322 Wabash Ave., Chicago 


57 
